BUDAPESTI CORVINUS EGYETEM

\title{
SZEGREGÁCIÓ A FEJEKBEN
}

\section{A STATISZTIKAI ÉS A MENTÁLIS TÁRSADALMI-ÉS TÉRBELI} ELKÜLÖNÜLÉS VIZSGÁLATA SZEGEDEN

Ph.D értekezés

Rácz Attila

Budapest 2012 


\section{Rácz Attila}

\section{SZEGREGÁCIÓ A FEJEKBEN}

A STATISZTIKAI ÉS A MENTÁLIS TÁRSADALMI-ÉS TÉRBELI ELKÜLÖNÜLÉS VIZSGÁLATA SZEGEDEN 
BUDAPESTI CORVINUS EGYETEM

Szociológia Tudományok Doktori Iskola

Témavezető:

Dr. Letenyei László Ph.D

egyetemi docens

(C) Rácz Attila 


\section{BUDAPESTI CORVINUS EGYETEM}

Szociológia Tudományok Doktori Iskola

\section{SZEGREGÁCIÓ A FEJEKBEN}

\section{A STATISZTIKAI ÉS A MENTÁLIS TÁRSADALMI-ÉS TÉRBELI} ELKÜLÖNÜLÉS VIZSGÁLATA SZEGEDEN

Ph.D értekezés

Rácz Attila

Budapest 2012 


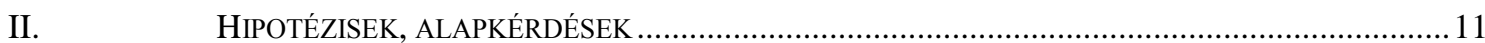

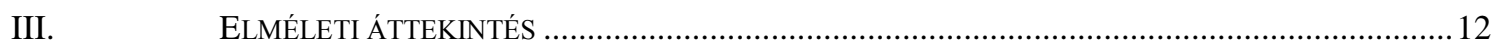

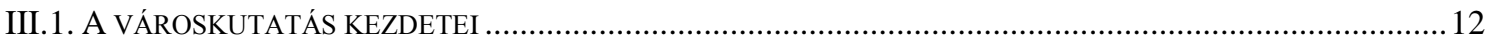

III.2. A TÉRBELI-TÁRSADALMI ELKÜLÖNÜLÉSSEL KAPCSOLATOS SZOCIOLÓGIAI ELMÉLETEK ........................14

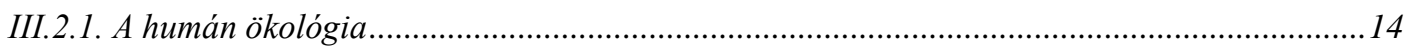

III.2.2. A városok belső tagozódásának humán ökológiai modelljei ................................................16

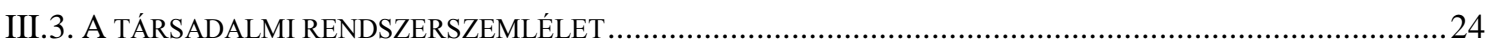

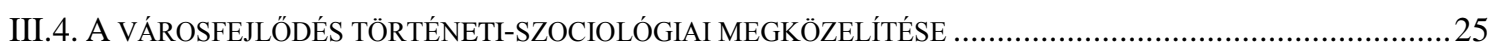

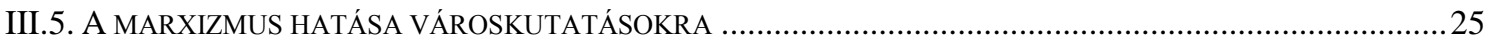

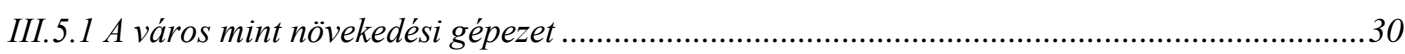

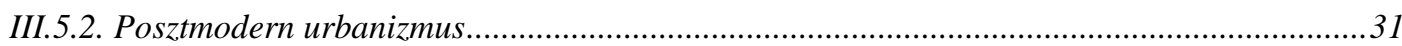

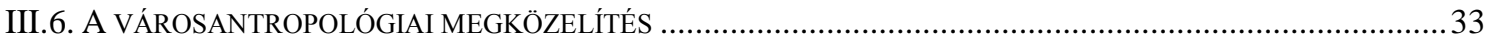

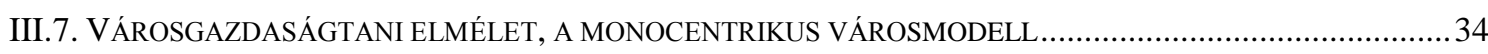

III.7.1. Externáliák, területhasználat és térbeli elkülönülés .................................................................34

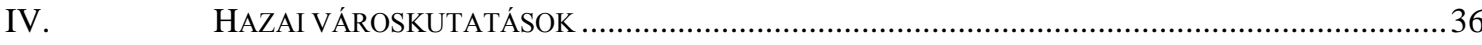

IV.1. AZ ÖKOLÓGIAI-TÁRSADALMI VISZONYOKAT MEGHATÁROZÓ MECHANIZMUSOK ....................................3

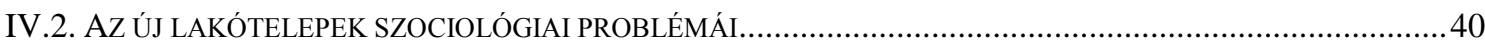

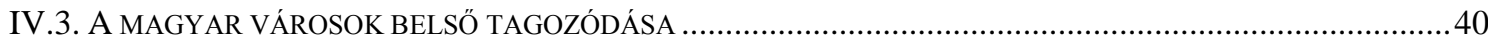

IV.4. A LAKÁS MINT A TÁRSADALMI EGYENLŐTLENSÉG KIFEJEZŐDÉSÉNEK ESZKÖZE ....................................42

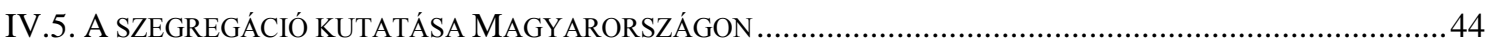

V. A TÁRSADALMI-TÉRBELI ELKÜLÖNÜLÉS VIZSGÁLATÁNAK FÖBB MÓDSZEREI .........................45

VI. A TÁRSADALMI-TÉRBELI ELKÜLÖNÜLÉST VIZSGÁLÓ KUTATÁSOK SZEGEDEN .......................48

VII. A KUTATÁS FOGALMI ÉS MÓDSZERTANI KERETEI..............................................................54

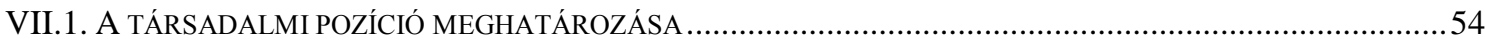

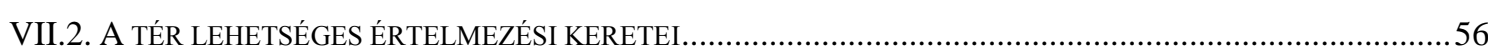

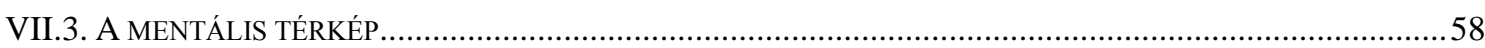

VIII. A MENTÁLIS TÉRKÉPEZÉS ELMÉLETI ÉS MÓDSZERTANI HÁTTERE ……………......................59

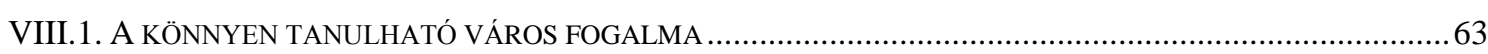

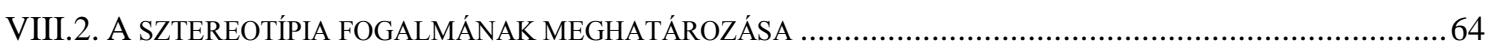

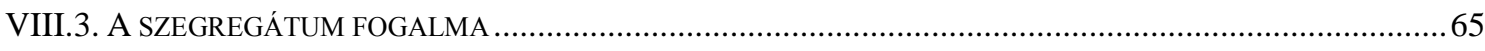

IX. A MENTÁLIS TÉRKÉPEZÉS HAZAI KUTATÁSI ELÖZMÉNYEI ....................................................

X. A VALÓS ÉS A MENTÁLIS TÁRSADALMI-TÉRBELI ELKÜLÖNÜLÉS ÖSSZEFÜGGÉSEINEK

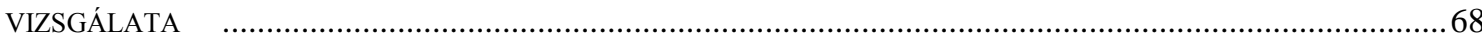

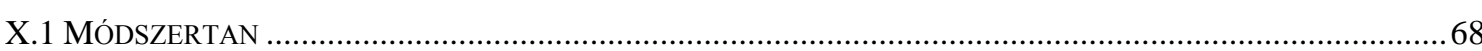

X.2. ElSÖ KUTATÁSI SZAKASZ: TEREPTÁVOLI ADATGYÜJTÉS. DOKUMENTUM-ÉS FORRÁSELEMZÉS .............73

X.2. Szeged városszerkezeti tagozódása ………………....................................................... 73

X.3. MÁSODIK KUTATÁSI SZAKASZ: TEREPKÖZELI ADATGYÜJTÉS. TEREPBEJÁRÁS, MEGFIGYELÉS, STRUKTURÁLATLAN INTERJÚK. 
X.4.1. A KSH által Szeged területén lévő szegregátumok lehatárolása, lehatárolt szegregátumok és veszélyeztetett területek bemutatása

X.4.2. A 2001-es népszámlálás adatainak másodelemzése. .90

X.5. ELEMZÉSI KÍSÉRLET AZ OBJEKTÍV ÉS SZUBJEKTIIV ADATOK MENTÉN. A TERÜLETI STATISZTIKAI ADATOK

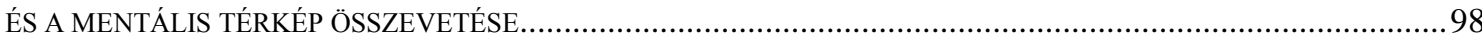

X.6. A MENTÁLIS SZEGREGÁTUM FOGALMÁNAK BEVEZETÉSE................................................................. 106

X.6.1. A valós és kognitív társadalmi-térbeli elkülönülés eltérö mintázatának magyarázatai .........109

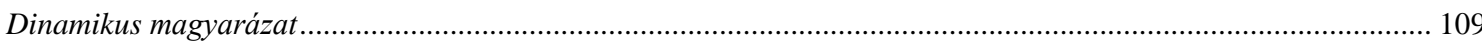

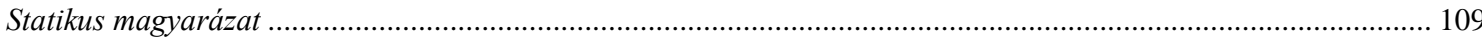

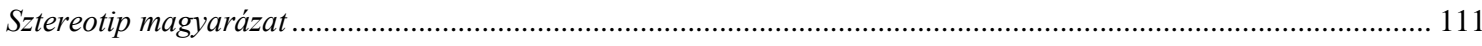

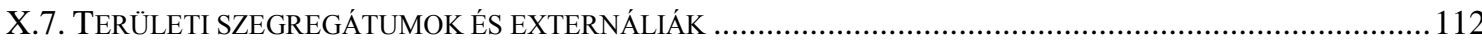

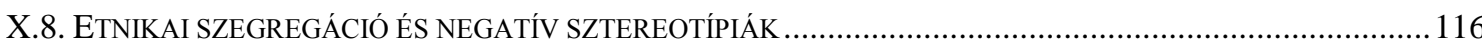

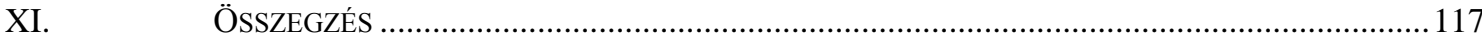

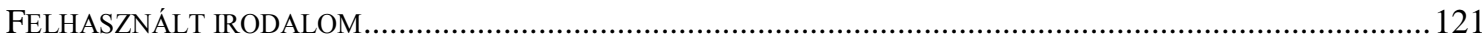

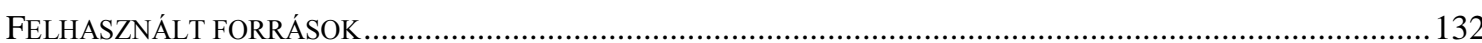

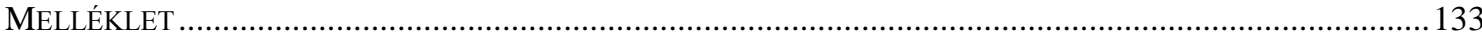

\begin{abstract}
Ábrajegyzék
1. ábra: Burgess koncentrikus körök városmodellje .17

2. ábra: Hoyt szektor városmodellje .18

3. ábra: Harris és Ullman többgócú városmodellje .19

4. ábra: Sztereotip extern hatások alakulása városrészenként Szegeden 115

5. ábra: Városrészenkénti sztereotíp extern hatások

\title{
Táblázatok jegyzéke
}

1. táblázat: Szeged különböző lakóterületeinek morfológiai jellemzőik szerinti csoportosítása, saját megfigyelés alapján 86

2. táblázat: Az alacsony és magas státusz kategóriájába sorolható szegedi lakosság szegregációs és disszimilaritási mutatói területi egységenként

3. táblázat: Az alacsony státuszúak szegregációs indexe funkcionális lakóövezetenként Szegeden a 2001-es népszámlálás adatai alapján 94

4. táblázat: A magas iskolai végzettségü, szellemi foglalkozásúak aktív korúakon belüli aránya területrészek szerinti szóródásának felbontása 
5. táblázat: A legfeljebb 8 általános iskolai végzettségü, aktív korú, munkanélküliek aktív korúakon belüli aránya területrészek szerinti szóródásának felbontása

6. táblázat: Szegények által lakottnak megnevezett területi egységek Szegeden. 102

7. táblázat: Gazdagok által lakottnak megnevezett területi egységek Szegeden. 102

8. táblázat: 2001-ben alacsony státuszúak által lakott területek és a mentális térképeken (említési gyakoriság szerinti) 2007-2009-2010-ben szegényként említett területek rangsorának összefüggései

9. táblázat: A 2001-ben magas státuszúak által lakott területek és a mentális térképeken (említési gyakoriság szerinti) 2007-2009-2010-ben gazdagként említett területek rangsorának összefüggései

10. táblázat: Mentális szegregátumok Szegeden 107

11. táblázat: A 2001-es népszámlási adatok valamint a mentális térképes adatfelvétel szerinti disszimilaritási és mentális disszimilaritási indexek városrészekre számított értékei Szegeden 111

\section{Térképek jegyzéke}

1. térkép: Szeged városrészei .83

2. térkép: A legfeljebb 8 általános iskolai végzettségü, aktív korú, munkanélküliek (piros) és a magas iskolai végzettségü, szellemi foglalkozásúak (zöld) aktív korúakon belüli aránya szerint sorba rendezett számlálótömbök legfelső decilisei Szegeden 2001-ben (saját szerkesztés) .95

3. térkép: Az alacsony (piros) és magas (zöld) státuszúak 2001-es népszámlálási adatok felső decilisei szerinti területi elhelyezkedés és a mentális térképeken említett szegények (sárga, narancs, rózsaszín) és gazdagok (kék) által lakottként említett városrészek, a lakótelepeken kirajzolódó sürüsödési pontokkal (fekete kör). Saját szerkesztés. 
Apa, és bennünket ki rajzolt ide?

Rácz Endre Attila (4 éves) 


\section{BEVEZETÉS}

Az értekezés során kvalitatív és kvantitatív kutatási módszerek alkalmazásával elemezzük Szeged „valós” és mentális társadalmi-térbeli mintázottságát, rávilágítva a területi alapokra épített társadalomtudományos elemzések módszertani problémáira az általunk alkalmazott különböző elemzési eljárások eredményeinek példáján keresztül. Az értekezés metodológiai szempontból interdiszciplinárisnak is tekinthetö, hiszen a dolgozat empirikus részét megalapozó különböző adatfelvételi módszerek és kutatási kérdések több tudományterületnek is - szociológia, gazdaságtudomány, társadalomföldrajz, szociálpszichológia, kulturális antropológia, urbanisztika - tárgyát, valamint módszertanát jelentik.

A fö irányvonalat a szociológiai megközelítés adja, így a klasszikus város-és településszociológiai elméletek, és ezekkel kapcsolatos kritikai értekezések mellett, a Szeged városában végzett empirikus kutatómunka és elemzés során leginkább Erdei Ferenc (1971) Szegeddel kapcsolatos írásaira, Szelényi Iván és Konrád György 1968-as (Szelényi 1990), valamint a KSH Csongrád Megyei Igazgatósága (Kovács 2003), és a Szegedi Tudományegyetem kutatói által (Bajmócy Péter, Boros Lajos, Kiss János, Mészáros Rezső, Pál Viktor) éveken át végzett Szeged belső tagozódásával kapcsolatos elemzéseire, továbbá Csanádi Gábor, Ekler Ferenc, Hegedủs József, Ladányi János és Tosics Iván elsősorban Budapesten, hasonló témában végzett kutatásaira alapozunk (Ekler-Hegedűs-Tosics 1980, Csanádi-Ladányi 1988, Ladányi 2008). A mentális térképezés módszerével végzett vizsgálatunk fő elméleti irányvonalát Kevin Lynch (1960) ,,könnyen tanulható város” fogalma köré építjük fel.

Az értekezés újszerüsége abban rejlik, hogy a különbözö kutatási módszerek ötvözésével végzett empirikus kutatássorozat eredményeként Szeged társadalmi-térbeli területi mintázatát, egybevetjük a városlakók helyi társadalmi-térbeli elkülönülésre vonatkozó mentális térképével, és a különbségekre és hasonlóságokra három lehetséges magyarázatot fogalmazunk meg.

A kognitív vagy mentális térképezés (cognitive/mental mapping) fogalmát Barbara Tverskyvel azonos felfogásban értelmezzük, vagyis a kétfajta fogalomhasználat között nem teszünk különbséget, mivel mindkét esetben a tudattartalmak feltárásáról, feltérképezéséről van szó, és a tudat vizsgálatakor képtelenség lenne a vizsgálatot csak és kizárólag a térrel kapcsolatos tartalmakra szükíteni, hiszen a kognitív folyamatok 
csak a maguk komplexitásában értelmezhetők. (Tversky 1993 - idézi: Letenyei 2004:154)

A területi szegregáció objektív és szubjektív létezését egyrészt a társadalmi rétegződés mint a területi elkülönülés magyarázó változójának a Peter Blau által definiált strukturális (nominális-graduális) paraméterek alapján (Blau 1976), másrészt a városlakók egyes területekhez kötődő, sztereotípiákra vonatkoztatott kognitív térképeinek összehasonlítása alapján határozzuk meg.

Az értekezésünk alapjában véve nem szegregáció-kutatás, azonban a téma érintése és bővebb kifejtése nem kerülhető el egy társadalmi-térbeli elkülönülést vizsgáló dolgozat esetében.

A szegregációkutatások a szociológiában a legtöbb esetben leginkább a szegénységi illetve etnikai - Magyarországon ezen belül is elsősorban a cigány lakosság által lakott - szegregátumok kutatására fókuszálnak. A szegénységi szegregátumok egyik legfőbb jellemzője, hogy a városokban ez a szegregátumtípus nem nagy területi koncentrációban, hanem leginkább kisebb összefüggő lakótömbökben jelenik meg (Csanádi-Ladányi 1988, Ladányi-Szelényi 1998, Ladányi 2000, Ladányi 2004, Ladányi 2005). Az értekezés során Szeged példáján át arra is rá kívánunk mutatni, hogy a szegénységi szegregátumok mellett létezik egy másfajta, társadalmi hatásait tekintve egyáltalán nem jelentéktelenebb szegregátumtípus is, nevezetesen a magasabb társadalmi státuszú népességet magában tömörítő gazdag-szegregátum. Ennek a típusnak egyik legfőbb jellemzője, hogy a szegénységi szegregátumok területi koncentráltságának mértékével ellentétben nagyobb területi koncentrációban jelenik meg (Ladányi 2005), továbbá területi és társadalmi állandósultsága kapcsán mélyebb lenyomatot is hagy a kognitív térképeken.

További jellemzője, hogy magasabb mértékü társadalmi zártságot mutat, ami abból adódik, hogy a szegregátum terültén található ingatlanok értéke is jóval magasabb, mint a nem szegregált városi területeken, így az alacsonyabb társadalmi státuszú népesség anyagi erejénél fogva sem képes ingatlant vásárolni, bérelni a gazdagszegregátumokban, másrészt a területen élők érdekérvényesítési potenciálja is magasabb, 
amellyel hatást tudnak gyakorolni az általuk lakott, és a más társadalmi csoportok által lakott területeket érintő központi döntéshozatalra is, fenntartva így területre jellemző társadalmi zárlatot.

Értekezésünk során a területi szegregátumokat a két fő társadalomtudományi kutatási módszer ötvözésével (kvalitatív-kvantitatív) írjuk le és határozzuk meg, ezen belül:

1. Források és dokumentumok adatainak felhasználásával

2. Megfigyeléssel, amelyet 10 évig folyamatosan végzünk és amelynek eredménye a kutatási probléma meghatározását generálja

3. Interjúk készítésével, melyet a megfigyeléses módszerrel egy időben párhuzamosan végzünk

4. Statisztikai adatok másodelemzésével. Ahol a KSH adatai alapján szegregációs és disszimilaritási indexek használatával mutatunk rá a területi-társadalmi egyenlőtlenségek mértékére, valamint az ezzel kapcsolatos módszertani problémákra

5. Mentális térképezés módszerével. Ahol nagymintás kérdőíves adatfelvétel adatainak elemzésével vizsgáljuk lakosság területekhez kötődő mentális reprezentációit

\section{HIPOTÉZISEK, ALAPKÉRDÉSEK}

Jelen értekezés fő kutatási problémája az, hogy a város lakóinak az egyes városrészekhez kötődő kognitív reprezentációi mennyiben mutatnak azonosságot az objektív adatok alapján leírható, adott területi egységben lakó népességre jellemző társadalmi helyzettel. Ezen belül, hogy a különböző szegregátumokat magukba foglaló területekhez kötődő kognitív reprezentációk hatással vannak-e az egyes részek megítélésére.

Értekezésünk fő irányvonalát a következő hipotézisek empirikus vizsgálata adja:

1. Domináns szegregátum hipotézis: A szegregátumok típustól függetlenül megjelennek a mentális térképeken. 
2. Mentális szegregátum hipotézis: A mentális térképeken megjelenő szegregátumok határai nem esnek egybe a kvantitatív adatok alapján mért és lehatárolt szegregátumok határaival, a mentális szegregátumok határai kiterjedtebbek.

3. Sztereotíp externália hipotézis: A szegregátumokhoz kapcsolódó sztereotípiák kiterjednek a szegregátumokat magába foglaló nagyobb városszerkezeti egységekre, Szeged esetében a városrészekre, és azokra kiterjedt pozitív vagy negatív extern hatásokat fejtenek ki.

\section{ELMÉLETI ÁTTEKINTÉS}

Értekezésünk ezen fejezetében a témához kapcsolódó elméleti keretek áttekintésére kerül sor. Igyekszünk áttekinteni a városszociológia kialakulásának főbb állomásait, továbbá kitérünk a városkutatás módszertani változásaira is. Ismertetjük a városi életmód valamint az ezekhez szorosan kötődő urbanizációs ciklus egyes lépcsőfokainak fogalmait, a nagyvárosok belső tagozódásával kapcsolatban született elképzeléseket, modelleket, valamint a városban végbemenő folyamatokat. Ezt követően áttekintjük a hazánkban végzett városszociológiai és területi szegregációval foglalkozó kutatásokat, érintve a magyar városi népesség térbeli strukturálódásának kérdését is. Kitérünk arra is, hogy korábbi kutatások és elméleti munkák tapasztalatai alapján a lakás és annak jellemzői milyen tényezőként jelennek meg a lakosság elkülönülése szempontjából.

\section{III.1. A városkutatás kezdetei}

A településszociológia kezdetei egybeesnek a tradicionális falusi társadalmak felbomlásával valamint az urbanizáció kibontakozásával. Az iparosodás kezdeti szakaszának óriási munkaerő-szükséglete fellazította a falusiak helyhez kötöttségét, s a falu lakói tömegesen vándoroltak a városokba. Az iparosodás és a városi fejlődés dezintegrációs hatást gyakorolt a társadalmi életre és fellazította az emberi kapcsolatok hagyományos mintáit.

A városszociológiai kutatások kezdetét a legtöbb kutató a 20. század elejére, az angliai ipari nagyvárosokban végzett empirikus kutatások idejére teszi. Ez az úgynevezett social survey időszaka, amikor az angliai városi lakosság kiterjedt szociológiai jellegü felmérésre kerül sor. Az időszak elsősorban Charles Both (Szelényi 
1973) és Le Play nevéhez kötődik, akik közül az utóbbinak Magyarországon végzett kutatómunkája a hazai szociológiai kutatások úttörőmunkájának is tekinthető (Le Play 1855, 1903). Az elméleti keretek összefoglalásakor a disszertáció kutatási módszerét is szem előtt tartva véleményünk szerint érdemes korábbra visszatekinteni a kezdeteket illetően. Nevezetesen Friedrich Engels 1845-ben végzett manchesteri városleírására (Engels 1845), amely a szó szoros értelmében nem tekinthető kiforrott empirikus módszerekkel történt városkutatásnak, de mindenképpen figyelemre méltó. Engels Manchesterben készült városleírása, módszerét tekintve az első ipari nagyvárosban készült terepmunkaként is értelmezhető, amely tartalmában megelölegezi a későbbi városszociológiai elméletek alapvető kiindulási pontját, nevezetesen, hogy a nagyváros társadalmának rétegződése és térbeli elhelyezkedése megfigyelhető, kutatásra érdemes társadalmi tény. Engels ezt a tapasztalatát, megfigyelőként fogalmazza meg. Leírásában az általa vélt okokat is papírra veti, amelyek felfoghatóak a terepmunka eredményeképp megfogalmazódott hipotéziseknek is.

Melyek azok az okok, amelyek meghatározzák a nagyváros különböző részein élő társadalmi rétegek elhelyezkedését? Tudatos várostervezési, építési elgondolások játszanak szerepet abban, hogy a szegény rétegek a fő közlekedési útvonalaktól elzárt, nem látható területeken laknak, ezáltal mintegy elrejtve a városi szegénység létét, vagy a városfejlődés sajátosságainak következtében alakul ki ez a mintázat?

Ezek azok a kérdések, melyeket Engels (1845) leírásában magyarázni igyekszik, és ezek a kérdések azok, amelyek a városszociológia hanyatlása után újra életre keltik a tudományágat, és mai magyar társadalompolitika aktuális kérdésévé is válnak napjainkra, s az úgynevezett antiszegregációs tervekben öltenek testet.

Fontos Max Weber munkásságát is megemlíteni, aki a város és nem utolsó sorban a falu teljesebb megértéséhez ugyancsak hozzájárult gondolkodásának, módszertani szempontjainak történeti szemlélete révén (Weber 1970). Weber munkásságában a leglényegesebb felismerés az volt, hogy a város egy sajátos típusa, nevezetesen a nyugati város, kedvező hatással van a tőkés gazdálkodásra, annak okán, hogy a nyugati városok fejlődésében létrejött - a feudális államon belül viszonylag önállóságot élvező - szabad polgárokból álló helyi közösségek révén, a városok előbb-utóbb autonóm közigazgatási és politikai egységekké váltak, ami a más jelleggel, más funkciókkal kialakuló keleti, ázsiai városokban nem következett be (Szirmai 1994). A 20. századi városkutatások 
azonban nem használták fel a szociológia klasszikusainál fellehető történeti elemzéseket, így Max Weber várostanulmányát sem (Szelényi 1973:16-17).

III.2. A térbeli-társadalmi elkülönüléssel kapcsolatos szociológiai elméletek

\section{III.2.1. A humán ökológia}

A térbeli-társadalmi elkülönüléssel kapcsolatos első szociológai elméletek tehát a 20. század elején végzett városkutatások eredményeképp születnek. A klasszikus városszociológia gyökereit jelentő elméleti kiindulópontok és elgondolások a humán ökológia tudományában jelennek meg (Nemes-Szelényi 1967), amelynek biológiai analógiákon alapuló szemléletmódjában jelentős szerepet kap az a nézőpont, mely szerint az élő organizmusok vizsgálata csupán akkor lehet eredményes, ha azokat a környezetük részeként értelmezzük. A környezetet vizsgáló autökológia mellett a szinökológia már arra helyezi a hangsúlyt, hogy az egyes, azonos területi egységen tömörülő élőlények között milyen kapcsolatok, kölcsönhatások játszódnak le.

Ez a szemlélet gyakorol jelentős hatást a chicagói egyetem szociológusaira, akik az elméletet a városok társadalmára adaptálják: „a város nem egyszerüen az emberek puszta 'homokkupaca', hanem társadalmi és fizikai jelenségeiben sok szálon egymásba szövődő és integrálódó egység” (Nemes-Szelényi 1967:92). Az ökológia tudományának hatására 1915-ben jelenik meg R. E. Park „, The City: suggestions for the investigation of human behavior in urban enviroment" címü tanulmánya, amely a városszociológia születését jelenti. Ebben a tanulmányban Park rendszerezett javaslatokat fogalmaz meg a szociológiai városkutatásokra. Ezt követően néhány évvel később Park és E. W. Burgess által közösen jegyzett, 1921-ben napvilágot látott „Introduction to the Science of Sociology” munkában kerül sor a kutatási terület konkrét elnevezésére, humán ökológia címszó alatt (Szelényi 1973:9).

A városi területek tanulmányozására több fogalmat, fogalompárt is kialakítottak illetve a humán ökológiától átvettek a chicagói iskola kutatói (Nemes-Szelényi 1967).

Szegregáció: A leggyakrabban előforduló fogalom a szegregáció, amely a városi lakosság egy-egy csoportjának térbeli elkülönülését jelenti, vagyis hogy „milyen egyenlötlenségek jelentkeznek a népesség meghatározott elemeinek ökológiai 
megoszlásában.” (Nemes-Szelényi 1967:95). Abban az esetben van szó a szegregáció hiányáról, hogyha a népesség a város minden részében ugyanolyan arányban van jelen, és akkor beszélhetünk jól kirajzolódó, teljes szegregációról, ha az egyes népességcsoportok egymással egyáltalán nem keverednek.

Szukcesszió (és „visszavétel”): A szukcesszió fogalma olyan értelmezési kategóriát biztosít, amelynek révén az előbbi szegregáció dinamizálható, ugyanis arra a folyamatra utal, melynek során „minden egyes belső övezet területét a hozzá legközelebb eső külső övezet elfoglalásával igyekszik kiterjeszteni (Burgess 1973:151).

Ennek következtében megváltozik az adott területen szegregálódó népesség társadalmi összetétele, hiszen a korábban ott lévő társadalmi csoportot egy másik váltja fel. A szukcesszió fogalma az egyazon helyen lezajló folyamatok időbeni változását jelenti, s ellentétpárjaként, kiegészítő párjaként használt fogalom a „visszavétel” (,withdrawal”) (Morris 1968:102).

Invázió (és „kihátrálás”): Ugyancsak ilyen fogalompárként értelmezhetők az invázió és a visszavonulás, kihátrálás („retreat”) jelenségei. Az invázió azt a térbeli mozgást jelenti, amelynek során egy népességcsoport bevonul egy másik csoport által birtokolt területi egységre, s akkor sikeres, ha a korábban jelen lévő lakosság elhagyja azt, kivonul onnan. A szukcesszió és invázió fogalmai értelmezhetőek úgy is, mintha lényegében ugyanarra a folyamatra utalnának, azonban míg a szukcesszió egy adott területi egységben az ott jelen lévő népesség időbeni változását jelenti, addig az invázió a csoportok térbeli mozgását követi nyomon, mely mozgás irányulhat a szukcesszió által érintett területre is (Morris 1968:102).

Koncentráció (és dekoncentráció): A koncentráció a népesség térben való eloszlásának változásaira utal, és főként két tényező hatása befolyásolja: egyrészt az egyes területek közötti migráció eltérő volta, másrészt a születések és halálozások révén előálló természetes folyamatok területenkénti eltérései (Morris 1968:101).

Centralizáció (és decentralizáció): A centralizáció fogalma azt mutatja, hogy a város hatóköre milyen mértékben terjed ki az azt körülvevő területekre, milyen mértékü és típusú estleges szolgáltatásokat nyújt a központ a térségben; az ipar, a kereskedelem, 
és az ezekhez kapcsolódó döntéshozatal müködésének centralizációja milyen mértékben valósul meg (Morris 1968:101).

A koncentráció és a decentralizáció közötti összefüggést Burgess a koncentrikus körök elméletének ismertetésekor a központosított decentralizáció folyamatával jelöli, vagyis hogy a városközponton kívüli üzleti alközpontok müködése a városmagban koncentrálódó nagyobb gazdasági egységbe történő beilleszkedés révén valósul meg (Burgess 1973:152).

\section{III.2.2. A városok belsö tagozódásának humán ökológiai modelljei}

A chicagói szociológusok felfigyeltek arra, hogy a városokban élő népesség elrendeződése, esetenkénti szegregációja bizonyos törvényszerüségek révén valósul meg: „A városi expanziót a népesség eloszlásának a folyamata kiséri, amelynek során az egyének és csoportok a lakhely és foglalkozás szerint rostálódnak, osztályozódnak és helyezkednek el" (Burgess 1973:153-154).

Kimutatták, hogy az egyes szociális rétegek, csoportok közötti társadalmi rétegződés miként jelenik meg, képződik le a területi dimenzióban, s hogyan ölt ily módon egyfajta társadalmi tény jelleget (Győri 2000:78). 


\section{A koncentrikus körök elmélete}

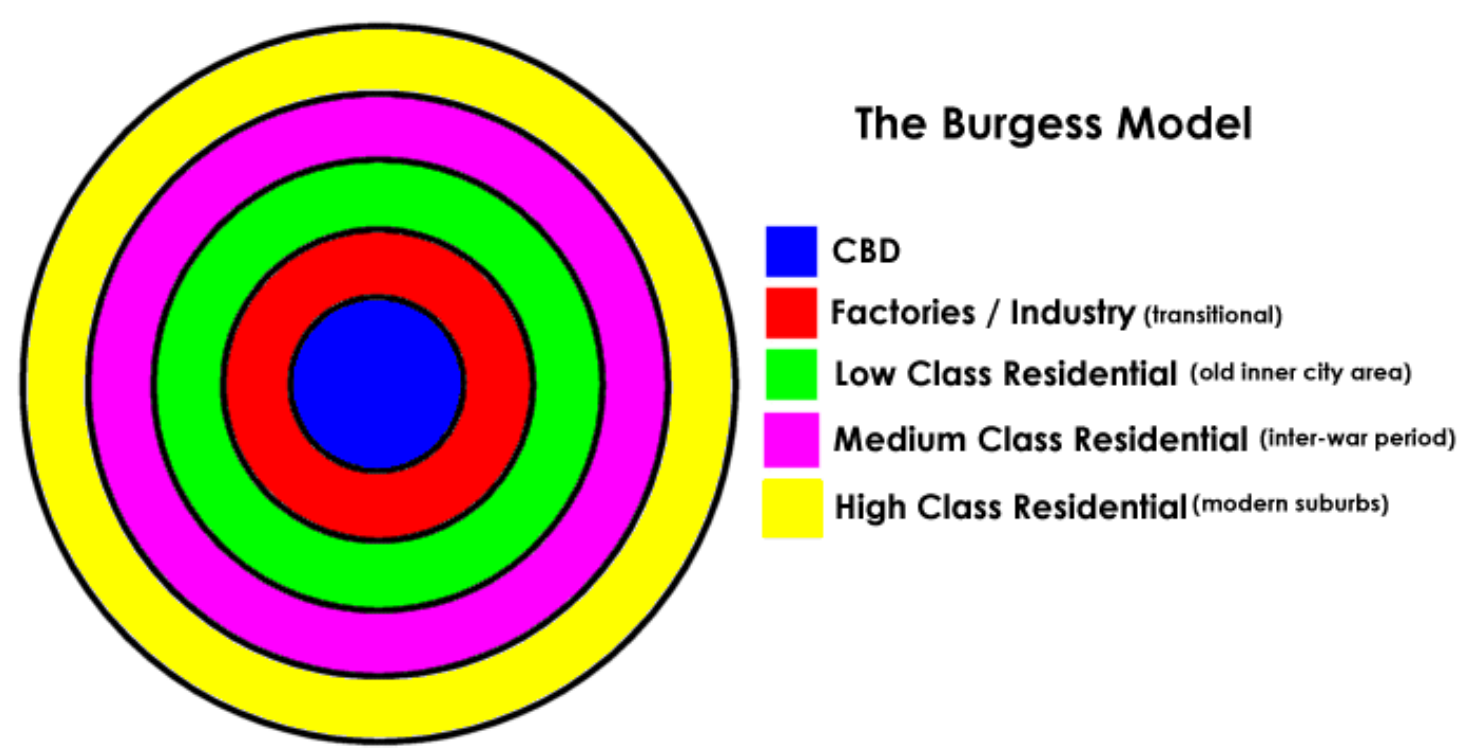

1. ábra: Burgess koncentrikus körök városmodellje

Forrás: 2010.08.23. http://www.revisionworld.co.uk/gcse/geography/settlement/burgess-modelmedc\&usg

A lakónépesség városban való elkülönülésének legkorábbi modellje Ernest Burgess (1973) koncentrikus köröket alkalmazó elképzelése, amely szerint a Belvárosban, a városmagban (CBD) összpontosulnak az igazgatás, az üzleti élet és a szórakoztatás funkciói, míg ezt az átmeneti övezet (transitional) veszi körül, melynek nagyméretű és romló állagú bérházai a vidékről felvándorolt munkások szállásául szolgálnak. A következő övezetben található az alacsony státuszú társadalmi csoportok ipari munkások otthona, akik igyekeznek kikerülni az előző átmeneti zónából, azonban a munkahelyüktől sem kívánnak eltávolodni.

Ezt követi térben tovább kifelé haladva a középosztály, majd pedig magas státuszú társadalmi csoportok villanegyedeinek gyürüje a város szélén illetve részben annak határán túl az elővárosokban és kertvárosokban. A modell jellegzetessége, hogy egy olyasfajta elrendezést képzel el, melyben a központtól kifelé haladva a harmadik gyürütől kezdve a lakónépesség társadalmi státusa növekszik: munkásosztály-zóna, középosztály által lakott gyürü, ingázók, bejárók zónája (Farkas 1998:31). A koncentrikus körök elmélete azt az állapotot jeleníti meg, ahogyan abban az esetben néz 
ki egy város, ha a közlekedési útvonalak minden irányban akadály nélkül terjedhetnek, és a telekárakat a gazdasági döntési mechanizmusok által szabályozott verseny befolyásolja (Morris 1968:34).

\section{A szektormodell}

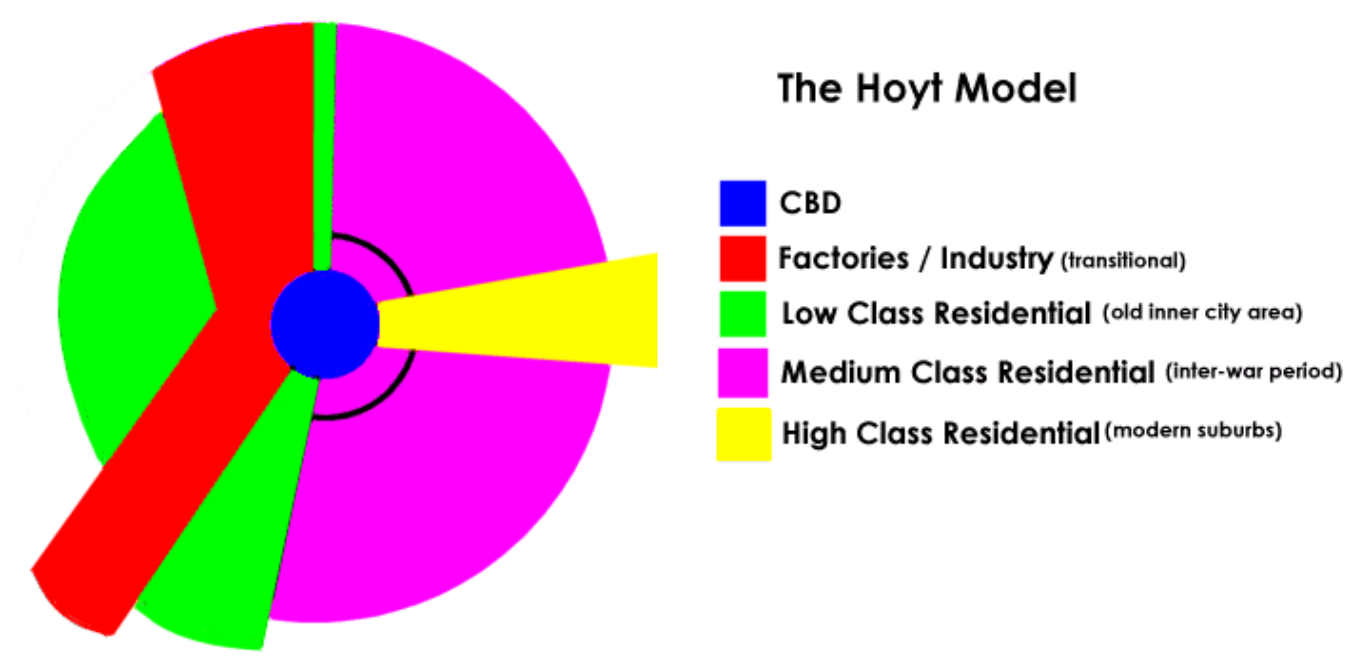

2. ábra: Hoyt szektor városmodellje

Forrás: 2010.08.23. http://www.bennett.karoo.net/images/urban/hoyt.gif\&imgrefur

A város belső tagozódásának egy másik elképzelése a szektormodell, melynek megalkotója Homer Hoyt, szisztematikus elemzés és folyamatos hivatkozás mellett értékeli újra a koncentrikus körök elméletében megfogalmazott modellt, és az annak megalkotása óta végbement változások figyelembevételével dolgozza ki az új szektormodellt (Hoyt 1964, idézi: Szelényi: 1973:161-181).

Ez az elképzelés elveti a város társadalmának koncentrikus körök mintáját követő térbeli szerveződésének elképzelését, és sokkal inkább egy sajátos „V” alakú elrendeződést képzel el. A kiinduló pont azonban itt is megegyezik: egy divatos, prosperáló terület (a központi üzleti negyed) fejődésnek indítja a vele szomszédos területet illetve területeket, vagy a környezet a fontosabb tömegközlekedési vonalak (villamos, vonat) mentén terjeszkedik tovább a távolabb lévő perifériák irányába. Ennek révén alakulnak ki a központtól kifelé nyíló jellegzetes formájú, tortaszelet alakra hasonlító városi körzetek. 
Nagy előnye ennek az elképzelésnek, hogy sokkal inkább figyelembe veszi az adott város területi, természeti meghatározottságát (dombok, hegyek, vízi utak), s így annak a város struktúrájára gyakorolt hatását (Shapiro 2002).

\section{A többgócú modell}
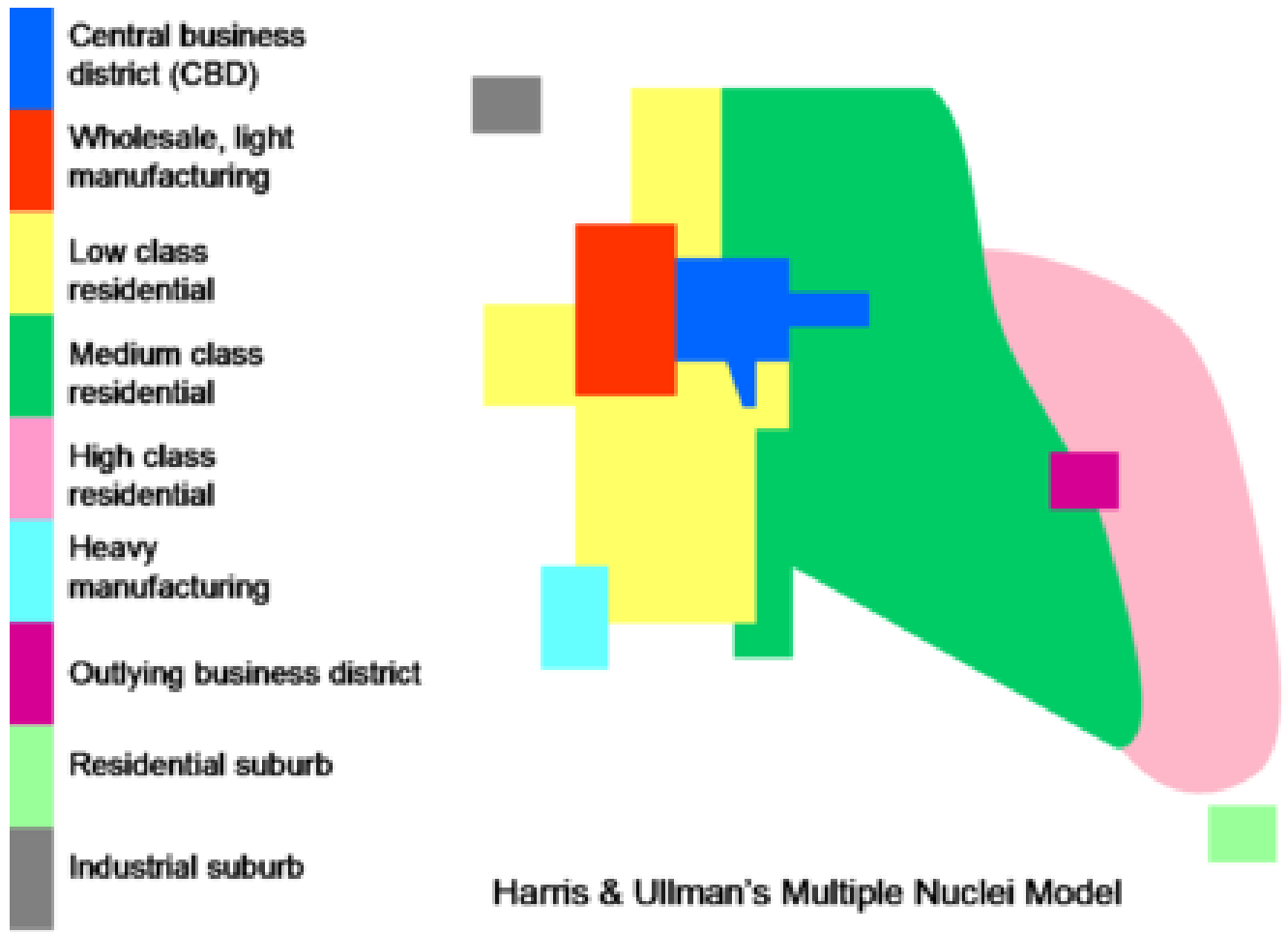

Harris \& Ullman's Multiple Nuclei Model

\section{3. ábra: Harris és Ullman többgócú városmodellje}

Forrás: 2010.08.23. http://www.bennett.karoo.net/images/urban/harris\&ullmann.gif\&imgrefur

Harris és Ullmann többgócú modellje egy harmadik elképzelésként fogalmazódott meg a városok népességének területi elkülönülését leírandó, amely legsikeresebben azon városokra alkalmazható, melyek más településeket olvasztottak magukba (Morris 1968:34). Itt már megszünik a korábbi két elméletben még jelen lévő központi negyed, mert a decentralizáció következtében a városban több különálló városmag, központ is kialakul. Ez úgy jön létre, hogy a város növekedésének következtében a lakókörzetek egymásba tolódnak; mindemellett az ipari parkok, a fóbb oktatási intézmények és bevásárlóközpontok környékére, azokhoz közel egyre több lakos kíván költözni, s így válik a város körzetek mozaikjává. Az, hogy egy adott településen mennyi városmag alakul ki, az elmélet szerint két tényezőtől függ: az egyik a terület térbeli-földrajzi, 
közlekedésbeli adottsága, a másik a térbeli expanzió következtében korábban a várostól külön létező települések, kisebb városok beolvadása (Shapiro 2002).

A három fó modell mellett létezik még az ún. hierarchikus elmélet, amely a városban futó közlekedési vonalak metszéspontjain kialakuló másodlagos és harmadlagos üzleti központok kifejlődésének tendenciáját regisztrálja. A hierarchikus modell, a szektormodell előzményének is tekinthető amely a tengelyszerü növekedéselméletre (Farkas 1998:32); valamint a társadalmi övezetre („social area”), továbbá az adott terület jellemzőinek gondosabb összegyüjtésére (Morris 1968:35), a társadalmi viszonyok intenzívebbé válására és a funkcionális differenciálódásra helyezi a hangsúlyt. A modell ezt hármas osztályozásban jeleníti meg: 1. gazdasági státusz (társadalmi rang), 2. családi státusz (urbanizáció), 3. etnikai státusz (szegregáció), melyekről amerikai és skandináv városok összehasonlító vizsgálata során bebizonyosodott, hogy fontos jegyei a városi társadalmi differenciálódásnak (Farkas 1998:33-34).

A városok belső tagozódásának feltérképezése következtében a chicagói iskola kutatói olyan sajátos, ideáltipikusnak tekinthető övezet-típusokat, területi egységeket írtak le, mint az általában az identitását sikeresen megőrizni tudó, éppen ezért azonban egyidejüleg izolálódó népesség által lakott gettó, a társadalom folyamatosan változó értékeit elfogadó és követő lakosságot tömörítő szuburbia, valamint a városok leromló, gyakran anomikus folyamatoknak teret biztosító slumjai (Nemes-Szelényi 1967).

A klasszikus városszociológia eredményei rámutatnak tehát arra, hogy a városi társadalom térbeni elhelyezkedése tagolt, bizonyos mintázottságot mutat, továbbá megtermékenyítőleg hatnak a későbbi, a városokban lejátszódó folyamatok és a társadalmi rétegződés összefüggéseinek tanulmányozását céljukként kitűző kutatók számára (Duncan-Duncan 2000, Rex 2000).

Az 1920-1930-as években a chicagói kutatók érdeklődési területe a városi deviáns viselkedési formák vizsgálata felé fordul, amely ebben az időben az észak-amerikai nagyvárosok legégetőbb problémái közé tartozik. W. I. Thomas munkásságának 
köszönhető az, hogy a Chicagói-iskola nem merül el teljesen a biologizmusban (Szelényi 1973:11). Az 1930-as évekre maguk a humán ökológusok - leginkább annak neoortodox irányzatát képviselő tagjai - is határozottan visszautasítják a bioökológia elméletén alapuló, a városszociológia szisztematikus kibontakoztatására történt ilyen irányú elméleti leszükítést. Az alapító, R. E. Park 1950-ben megjelent „Race and Culture” címü tanulmánykötetéhez írt bevezetőjében maga is határozottan kijelenti azt, hogy „,amikor ö és munkatársai humán ökológiáról beszéltek, városszociológiára gondoltak” (Szelényi 1973:13).

A harmincas évek elejére kialakul az ökológiai szemlélet új irányzata, amely a statisztikai-demográfiai megközelítésre helyezi át a hangsúlyt a városszociológiai vizsgálatoknál. Ez a szemléletmód azt hangsúlyozza, hogy az ökológia speciális, gazdasági-földrajzi adatokat szolgáltat a szociológiai kutatások számára. Ettől a szemléletmódtól határolják el magukat a neoortodox ökológia képviselői, kiknek vezéregyénisége A. H. Hawley szerint szükséges a bioökológiához való visszatérés a térbeli-társadalmi folyamatok vizsgálatánál. Álláspontja szerint olyan általános ökológiai tudomány kidolgozására van szükség, amely szemléletmódjában hasonló mind a biológiában, mind a társadalmi szférában. Ennek az irányvonalnak a legdemonstratívabb megnyilvánulása az ökoszisztéma elvének átültetése a társadalomkutatásra. Az elmélet szerint az ökoszisztéma egy olyan átfogó rendszer, amely a biotikus társulást és annak környezetét is egyaránt tartalmazza.

A neoortodox elméleti alapokon gondolkodó szociológusok közül O. D. Duncan kísérli meg az ökoszisztéma elvének társadalomtudományi átültetését. Azt hangsúlyozza, hogy a társadalmi szervezetek is csak a környezetükkel való kölcsönhatásukban érthetőek meg, így azt a tételt fogalmazza meg, hogy maga a társadalom is egy ökoszisztéma részeként müködik (Szelényi 1973:13).

Másfajta felosztásban, de lényegében hasonló gondolatokat fogalmaz meg a városszociológia lehetséges nézőpontjainak kérdésében R. N. Morris, aki szerint két fö megközelítési mód létezik e tudományterületet illetően. Az egyik az ökológiai szemléletmód, amelynek értelmében a város lényegét a nagy népesség viszonylag kis területen való koncentrációja jelenti, a másik elképzelés szerint - amelyet a szerző szervezeti megközelítésnek nevez - a város tanulmányozásakor egy sajátos viselkedési minta felderítésére kell figyelmet fordítani (Morris 1968). 
A további elméleti útkeresésben kiemelkedő szerepe volt L. Wirthnek, aki a humán ökológia eredményeit a klasszikus szociológia kérdésfeltevéseivel kapcsolta egybe. Wirth a nagyvárosokban gyakrabban megjelenő patologikus jelenségeket, valamint az emberi kapcsolatokban tapasztalt válságjeleket a nagyváros három lényeges tulajdonságival magyarázta: a nagy lélekszámmal, a népsürüséggel valamint a város társadalmi szerkezetének nagyfokú differenciáltságával (Wirth 1938). Wirth a fent felsorolt tényezők figyelembe vételével értelmezte a város általános társadalmi jellegzetességeit, miszerint a három tényező egy sajátos típusú társadalmi szerveződést illetve életformát eredményez: az urbanizmust, melyet a másodlagos csoportkapcsolatok dominanciája és az elsődleges kapcsolatok felbomlása jellemez.

Wirth elméleti koncepciója viszonylag hosszú időre megalapozta a városkutatások gyakorlatát, melyet később R. Redfield „folk-társadalom” elmélete erősített meg. Redfield a tradicionális népi közösséget vizsgálta és a városi társadalom ellenpólusaként olyan integrált egységnek írta le, amelyet teljesen átfognak és meghatároznak a családirokoni-szomszédsági kapcsolatok (Redfield 1947).

A későbbi, a szomszédsági kapcsolatok integráltságának térbeli-társadalmi dimenzióban értelmezett elkülönülését vizsgáló empirikus kutatások eredményeinek tükrében olyan álláspont alakult ki, hogy a nagyvárosokban mind a wirth-i, mind a redfieldi modell megtalálható. A nagyvárosokban kimutathatóak az emberi kapcsolatok tradicionális, falusi és modern, városi formái is (Castells 1972).

A városi emberi kapcsolatok problémakörére fókuszáló kutatások során 1960-ban S. F. Fava New Yorkban végzett kutatásának eredményeként arra a következtetésre jut, hogy a nagyváros három különböző negyedében (a központban, a városszélen és egy szuburb negyedben) a szomszédsági kapcsolatok annál erősebbek, minél messzebb van az adott városrész a belvárostól (Fava 1960), ezért a belvárosi és a szuburb életforma közötti radikális különbség alapján indokoltnak látja a wirth-i „urbanizmus” mellett a „Szuburbanizmus mint életmód” kategória bevezetését (Szirmai 1994).

A Londonban végzett empirikus kutatásaik során P. Willmott és M. Young szintén arra a megállapításra jutnak, hogy a tradicionális kapcsolatok a város régi, belső 
munkásnegyedeire jellemzőek, míg a modern városi élet a középosztály által lakott külvárosokra. Willmott és Young a társadalmi szerkezetet vélik meghatározónak, mint az életmód, magatartás és kultúra alapvető változója. Kutatásaik szerint a munkásnegyedek társadalmi viszonyait nem határozzák meg az urbanisztikai feltételek, az nem az adott társadalmi csoport ökológiai helyzetéből következik. A középosztály befeléfordultsága, kapcsolatnélkülisége viszont ökológiai viszonyokkal, urbanisztikai feltételekkel is csak nehezen befolyásolható. Ugyanakkor megállapítják, hogy az ökológiai viszonyok változása végül is befolyással van a középosztály társadalmi helyzetéből magyarázható életmódjára, így a város társadalmi jellegzetességeinek alapvető változója a társadalmi struktúra, de hatásának érvényesüléséhez a megfelelő ökológiai feltételek is szükségesek (Willmott-Young 1960).

Néhány évvel később H. Gans 1962-ben a témában megjelenő, összegző jellegü dolgozatában ugyancsak a belváros jellegzetességének tartja a Wirth által leírt életformát, a tradicionális kötödések továbbélését pedig a külváros sajátjának tekinti.

Gans vonja le elsőként általánosító jelleggel azt a következtetést, hogy - szemben a wirth-i koncepcióval - nem beszélhetünk egységes nagyvárosi életformáról, és hogy a városban létező sokféle életforma magyarázatánál alapvetően nem az ökológiai viszonyokból, hanem a társadalmi-foglalkozási rétegződésből kell kiindulni (Gans 1962).

A hatvanas évektől kezdődően egyre több kutató vonja kétségbe a humán ökológia magyarázó elveit. H. Hoyt a városi szerkezet időbeni változásait vizsgálja, és kimutatja a klasszikus városszerkezet modelljének a torzulásait (Hoyt 1964, idézi: Szelényi: 1973:161-181). Tanulmányában kifejti, hogy a húszas évek óta lezajlott városnövekedési, valamint egyéb folyamatok eredményeként megváltozott a városszerkezet klasszikusnak hitt modellje. A városnövekedés a centrumból áttevődik az elővárosokba, miközben megváltozik a központok etnikai összetétele is. A középosztály jövedelmi viszonyainak emelkedése miatt is a fehér lakosság a belvárosból, de az átmeneti övezetből is kiköltözik a kertvárosokba. A 20-as, 30-as években a nagyvárosokat még nem veszi körül kertvárosi gyürü. Hoyt szerint a magángépkocsik majdhogynem általánossá válása igen fontos tényezője a városi lakosság kiáramlásának, 
a családi házak vasútvonalaktól távol eső építésének, valamint a bevásárlóközpontok és szétszórt ipartelepek kialakításának (Szirmai 1994).

A humán ökológia elméleti meghaladását egész sor empirikus kutatás eredménye készíti elő. Gint és Fava az amerikai kertvárosokban végzett kutatásaik eredményeként rámutatnak, hogy e lakónegyedek jellegzetes életmódja nem ökológiai jellemzőkből, hanem az amerikai társadalom általános értékeiböl, az egyéni fogyasztást elöíró normatívákból adódik (Gint-Fava 1964).

\section{III.3. A társadalmi rendszerszemlélet}

A társadalmi rendszer elmélete a szociológiai gondolkodásban visszavezethető egészen Vilfredo Parétóig, akinek szemléletében a társadalom úgy jelenik meg, mint különböző erők egyensúlyi állapota (Nemes-Szelényi 1967).

A társadalmi rendszerszemlélet és a modern ökológia közös pontja a városkutatások történetében az, hogy mindkét elmélet a települést mint rendszert értelmezi. A település mint rendszer értelmezésekor különös figyelmet kapnak a különböző tudati jelenségek valamint a kultúra. A társadalmi rendszerszemlélet alapján végzett városkutatások legfőbb problémáját az okozza, hogy a települések - legföképp a nagyvárosok - az iparosodás és a bürokratizálódás során jelentős mértékben veszítenek integráltságuk fokából, ami tulajdonképpen egy dezorganizációs folyamatként is felfogható. A humán ökológiai elmélet azonban már a kezdetektől fogva vitatta a városfejlődés dezorganizációs felfogásának helyességét, így a társadalmi rendszerszemlélet koncepciója és a humán ökológiai gondolkodás a rendszer meghatározásának és alapvető müködésnek kérdésben ellentmondásba kerül (NemesSzelényi 1967).

Erre a problémára próbál választ keresni R. R. Warren és I. T. Sanders, akik munkásságuk során azt igyekeznek kimutatni, hogy az amerikai nagyvárosokban melyek azok a funkciók, amelyeknek a társadalmi integráltság szempontjából lokális relevanciájuk van (Szelényi 1973:16). 
III.4. A városfejlődés történeti-szociológiai megközelítése

„Az ökológiai gondolkodás és a társadalmi-rendszerszemlélet közös fogyatékossága, hogy nem vagy csak alig képes a várost, mint történeti jelenséget értelmezni [...]”" (Szelényi 1973:16).

A városkutatások átterjedése az Egyesült Államok területéről más kontinensekre, megvilágítja azt a problémát, hogy az amerikai városmodelleknél megfogalmazott fejlődési folyamatok és városszerkezeti elképzelések nem fogadhatóak el általános törvényként a nagyvárosok mindegyikére. Az észak-amerikai nagyvárosok empirikus vizsgálatai során megfogalmazott „törvényszerüségek” csak egy adott történeti kontextusban állják meg a helyüket, ezért a városkutatás nem hagyhatja figyelmen kívül azokat a történeti folyamatokat, amelyek hatással vannak egy-egy város fejlödésére. Ennek újbóli felismerésén alapul G. Sjoberg, L. Reissman, és hazai viszonylatban Erdei Ferenc munkássága is.

Sjoberg A preindusztriális város (1955 idézi: Szelényi 1973:108-122) címü tanulmányában a történeti folyamatok tükrében vizsgálja, hogy az ipari forradalom előtti városok fejlödésének milyen közös szakaszai figyelhetőek meg. Elemzésében megállapítja, hogy bizonyos strukturális elemek egyetemesek minden városi központban, de ezek a strukturális elemek ugyanakkor a preindusztriális városokban különböznek az ipari városokban megfigyelhető formáktól.

A városszociológia fejlődése szempontjából kiemelt figyelmet érdemel Riesman (1966 idézi: Szelényi 1973:122-147) különböző történeti fejlődési szakaszokra kidolgozott tipológiája, ami a különböző történeti fejlettségi szinten lévő társadalmak városainak fejlődési sajátosságait helyezi rendszerbe. A tipológia alapvető hiányossága Szelényi Iván szerint az, hogy túlságosan tapad a társadalmi-gazdasági rendszer változásaiból fakadó különbségekhez, valamint a kelet-európai és ebböl adódóan a magyarországi városfejlődés esetében figyelmen kívül hagyja a szocialista termelési mód városfejlődésre gyakorolt hatásait (Szelényi 1973:17).

III.5. A marxizmus hatása városkutatásokra 
Az 1970-es évektől az újra megújuló városkutatások elméleti hátterére egyes kutatók szerint a marxista konfliktuselmélet erős hatása érezhető (Soja 1989, Giddens 1997, Logan-Molotoch 1999, Orum-Chen 2003, Shields 2004, Aronowitz 2007, Peet 2006, Castells 1989, 2007, Boros 2011) ezért leginkább a geográfiai városkutatással foglalkozó szakirodalom ezeket a 70-es években újrainduló kutatási irányzatokat „neomarxista” irányzatnak is nevezi.

Véleményük szerint a 20. század második felében a nyugati városkutatások elméleti hátterére talán Marx gyakorolta a legnagyobb hatást - annak ellenére, hogy gyakorlatilag nem írt semmit, amit városszociológiaként értelmezhetnénk, ellentétben Friedrich Engelssel, aki A munkásosztály helyzete Angliában (1980) címü munkájában a manchesteri mellett, több ipari forradalom korabeli angol nagyváros társadalmának kiváló leírását adja.

A „neomarxisták” - ellentétben a humánökológiával - nem a természetesnek tekintett térbeli folyamatokat helyezik elméleti keretük középpontjába, hanem azt, hogy miként hat a hatalom a tájra és a mesterséges környezetre. A lényegében konfliktuselméleti megközelítés determinálta továbbá azon elgondolásukat, hogy a kapitalizmus rejtett struktúrái alapvetően befolyásolják a települések müködését, az azokon belüli egyenlőtlenségeket. Meghatározónak tartják a struktúrát az emberi szereplőkkel és viselkedéssel szemben is. Vizsgálataikban leginkább a politikai gazdaságtanra és a történelmi materializmusra építenek, fogalomhasználatukban meghatározóak az olyan marxi kategóriák, mint az osztály, az osztályellentétek vagy termelőerők, termelési viszonyok. Álláspontjaik sok esetben egymással ellentmondóak és gyakran vitákba keverednek. A hangsúlyokat illetve meghatározó tényezőket illetően azonban több közös jellegzetesség is összeköti őket (Giddens 1997, Orum-Chen 2003).

A „neomarxista” városkutatók közül a francia filozófus és szociológus, Lefebvre volt az első, aki a marxi megközelítést kiegészítette a tér fogalmával. Lefebvre a mindennapok gyakorlatát helyezte vizsgálódásai középpontjába, melyben a tér ugyanolyan fontos szereppel bír a társadalomfejlődésben, mint az idő (Aronowitz 2007; Boros 2011). Lefebvre szerint a társadalom müködéséhez, a kapcsolatok létrejöttéhez szükséges a térbeli közelség vagy valamiféle térbeli kapcsolat. Emellett szerinte egy társadalom müködését befolyásolja, hogy milyen annak a térbelisége (Lefebvre 1991, 
Shields 2004). Szerinte a kapitalizmus térszerveződése a mindenkori termelési igényekhez igazodik (Orum-Chen 2003), és ezek adják a magyarázatát annak, hogy a 20. század gyakori gazdasági és politikai megrázkódtatásainak (válságok, háborúk) ellenére kapitalizmus hogyan tudott fennmaradni (Aronowitz 2007).

Lefebvre gondolkodásában a marxi értelemben vett alap az a mindennapi élet, amely során a termelés és a társadalom újratermeli önmagát, mint rendszert. A mindennapi életnek a szerepe ennél fogva meghatározóbb, mint a termelési módnak. Központi szerepet tulajdonít a „térteremtés”, „tértermelés” és a városi fejlődés összekapcsolásának. Elméletének fő gondolatmenetét képezi, hogy a térbeliség a termelés társadalmi viszonyait tükrözi vissza, és elveti azt a felfogást, amely a teret valamiféle objektív valóságként értelmezi.

Lefebvre fogalmazza meg először azt a mára már széles körben elfogadott nézetet, hogy a tér társadalmi konstrukció, amelyet az értékek és a különféle jelentések, értelmezések határoznak meg, és ebből adódóan a tér társadalmi meghatározottsága közvetlenül hat a mindennapi cselekvésekre, és arra, ahogy a világot látjuk, ezáltal a térnek ideológiai funkciója van.

Lefebvre szerint a városi tér teremtése alapvető fontosságú a társadalmi újratermelésben, azaz a kapitalizmus müködésében és ebben - mint általában az a marxista típusú elméletekre általában jellemző - az uralkodó osztály szerepe meghatározó, mivel a saját érdekei szerint irányítja a folyamatot, és kulcsfontosságú számára hatalma megőrzése. Ennek következtében a kapitalizmus folyamatosan újratermeli önmagát - tehát Marx téved a kapitalizmus szükségszerü bukásával, és a kommunizmus győzelmével kapcsolatban (Lefebvre 1991; Aronowitz 2007).

Lefebvre azzal, hogy a „hely” helyett a teret állította elmélete középpontjába, nemcsak eltávolodott a helyközpontú chicagói iskola hagyományaitól, hanem egyben a filozófiai gondolkodással - a tér és az idő problematikájával - is összekapcsolta a városkutatást (Orum-Chen 2003). A városkutatások történetében elsőként szakít azzal a passzív térszemlélettel, amely a teret egyszerü „tartályként” látja, ahol az események végbemennek, ám azokra nincs különösebb hatása. 
Harvey - aki nagyban épített Lefebvre munkásságára - a településkutatásban elveti az 1960-as évektől a társadalomtudományokban megerősödő fenomenológiai megközelítések alkalmazását, mert szerinte ezek csak idealizmushoz vagy naiv empirikus elemzésekhez vezetnek - mint ahogy azt véleménye szerint a geográfia behaviorista forradalma és ahhoz kapcsolódóan a mentális térképezés módszere be is bizonyította. Szerinte a valóságból kell kiindulni, de nem a pozitivizmust használva (mivel szerinte az épp a lényeget, a kapitalista gazdaság sajátosságait hagyta ki elemzéseiből), hanem a materialista marxi elméletet, amely abból a célból akarja megérteni a világot, hogy meg is változtassa azt (Peet 2006). Harvey továbbfejleszti Lefebvre gondolatait a tér teremtéséről: megfogalmazása szerint a modern urbanizmus esetében a teret folyamatosan újrakonstruálják a kapitalizmus továbbélésének, erősödésnek érdekében. Ugyanakkor a tér visszahat az őt formáló folyamatokra - ezt nevezi Soja (1989) a tér és a társadalom dialektikájának.

E folyamatot az ipartelepítéssel, termeléssel kapcsolatos nagyvállalati és kormányzati döntések határozzák meg (Giddens 2003). Ehhez kapcsolható Harvey (1985) álláspontja, miszerint a piaci és a hozzátartozó hatalmi struktúra nem csak a társadalmat, hanem a teret is (át)strukturálja saját igényeinek megfelelően.

A „neomarxista” kutatók harmadik képviselője, Castells némiképp más gondolatmenetet képvisel, mint Lefebvre és Harvey. Munkásságában összekapcsolja az európai elméleti tradíciót az amerikai empirikus hagyománnyal, így talán hozzá köthető a kétféle városszociológia ,szintézise”. Castells szerint a modern társadalomban az elsődleges ellentét a tőke és a munkaerő között van, amelyhez képest másodlagos a fogyasztáshoz, rendelkezési joghoz kapcsolódó konfliktus (Orum-Chen 2003).

Castells korai munkáiban hangsúlyos szerepet kap az a gondolat, hogy a település a kollektív fogyasztás szerves része, ami pedig az ipari kapitalizmus elválaszthatatlan eleme. Castells nem kevesebbet állít mint azt, hogy a város fizikai képe a fogyasztáshoz kapcsolódva alakul ki, ezt a folyamatot pedig a különböző (piaci és nem piaci) döntéshozók irányítják. Ehhez a vártnál nagyobb súllyal kapcsolódnak az alulprivilegizált csoportok, akik életfeltételeik megváltoztatásáért küzdve különféle mozgalmakat hoznak létre (Lowe 1986, Giddens 2003). Első elemzéseiben idealizálja a társadalmi mozgalmakat, egyértelmủen pozitív szerepet tulajdonítva nekik (Lowe, 
1986). Később változtat ezen a véleményén, és nem kapcsol értékítéletet ezekhez a társadalmi intézményekhez (Castells-Ince 2006).

Az amerikai városokban a 20. század végén megjelenő erősödő polarizáció, szegénység és kirekesztés Castells szerint előre jelzik a jövő útjait a világ más részein. Igaz, hogy az amerikai társadalom sajátos városformát alakított ki, illetve sajátos a társadalmának értékrendje, ám a globális összefonódások és az uralkodó kapitalista minta egyértelműen kijelöli a fejlődési utat a világ Egyesült Államokon kívüli részei számára is. Az elmúlt évtizedek - miközben dinamikus termelékenység-növekedést hoztak az Egyesült Államokban - nem teremtették meg az egész társadalom helyzetének javulását. Megfogalmazásával élve egy kettős Amerika, illetve ehhez kapcsolódóan egy kettős város jön létre, amelyben a széthullás, a polarizáció tendenciái jellemzőek.

Az 1980-as évektől megugrik a hajléktalanok száma az amerikai nagyvárosokban, és a szegénység, a nyomor kialakítja azt a stigmát, amely tartós kirekesztést hoz létre. A személyiség és a személyes kapcsolatok egyaránt felmorzsolódnak - ezáltal az információs kapitalizmus a szegénység erősödő trendjén keresztül a kirekesztés erősödéséhez vezet (Castells 1989, 2007).

A „neomarxista” kutatókat gyakran éri kritika amiatt, hogy túlságosan determinisztikus a felfogásuk és a társadalomtudományt megosztó „structure-agency” vitában egyértelmüen a struktúra mellett foglalnak állást, negligálva ezzel az egyének és csoportok szerepét a társadalom müködésében. A vita lényege, hogy a makrostruktúrák, vagy az egyéni, esetleg csoportos szereplök (,,agency-k”) a meghatározóak a társadalmi folyamatokban, illetve, hogy maguk az egyes szereplök milyen mértékben tudják befolyásolni a struktúrák alakulását. (Mint azt láthattuk, Castells már eltávolodott ettől az állásponttól azzal, hogy a városi társadalmi mozgalmak szerepét hangsúlyozza.) Az osztályfogalom használatát szintén többen kritizálják, mivel az ezredforduló társadalmainak elemzésére sokan nem tartják megfelelő keretnek az osztályalapú felosztást. 


\section{III.5.1 A város mint növekedési gépezet}

Logan és Molotoch nevéhez köthető a „neomarxista” irányzat sajátos továbbfejlesztése, amelyben vitatják a makrostruktúrák kizárólagos jellegét. A koncepció kidolgozói bizonyos értelemben összekapcsolják a „neomarxista” kritikát az ökológiai állásponttal, és elméletükbe beépítik a neomarxizmust ért bírálatokat is. Egyetértenek többek közt Castells-szel és Harveyval abban, hogy az országos és a nemzetközi gazdasági tényezők erőteljesen befolyásolják a városi életet, és a város a kapitalista tőkeakkumuláció színtere, ám hangsúlyozzák azt, hogy a lokális szereplök szándékai ugyanilyen erősen szerepet játszanak abban, hogy miként fejlődik a város (Logan-Molotoch 1999). Logan és Molotoch szerint a piaci folyamatok mellett lényeges az is, hogy a különböző csoportok mire akarják használni az egyes területeket. A kérdés tehát nem csak az, hogy ki dönt, hanem az is, hogy milyen céllal? Ezek a szándékok természetesen gyakran egymással ellentétesek - azaz konfliktusok kialakulásához vezetnek.

Ezek a konfliktusok pedig a városnegyedek strukturálódásának legfontosabb tényezői. Ilyen konfliktus például, amikor egy városrész elsődleges funkcióban eltérő szerepben jelenik meg. Az ott élők számára elsősorban otthon, míg a vállalkozók számára a termelés, a bevételszerzés színtere. A bevételszerzés logikája az intenzív területhasználatot diktálná, míg az élhető városrész létrehozása a közvetlen hasznot nem hajtó, beépítetlen, rekreációs terek fenntartását kívánná meg. Logan és Molotoch hasonló következtetetésre jut mint Castells: az egyes negyedek lakói saját civil kezdeményezéseik révén küzdhetnek meg a „növekedési gépezettel”. Így helyi mozgalmak indulhatnak az övezeti építési korlátozások kiterjesztéséért, vagy a kedvezőbb bérleti díjak érdekében (Logan-Molotoch 1999, Giddens 2003).

Logan és Molotoch alapvetése az, hogy a város az elitek számára müködik „növekedési gépezetként”: ők azok, akik a profitot felhalmozzák. A profitérdek összekovácsolhatja a különböző eliteket, nem számít, hogy más kérdésekben mennyire megosztottak, és így növekedési koalíciókat (más néven rezsimeket) hoznak létre. Annak érdekében, hogy saját konszenzusukat közmegegyezéssé tegyék, mindent megtesznek, hogy az alternatív elképzeléseket visszaszorítsák, diszkreditálják, és a saját álláspontjukat legitimizálják, így a vélemények pluralizmusa sokszor csak látszólagos. 
Az üzletemberek és a politikusok mellett a helyi média is fontos szereplöje a növekedési gépezetnek. A média érdekelt a város növekedésében és terjeszkedésében, hiszen ezzel a vásárlói száma is nő, másrészt az egyes lapok, televízió és rádióadók többnyire az adott médiát finanszírozók érdekeit követik. Emellett kiegészítő szereppel a különféle oktatási és kulturális intézmények, szervezett sportesemények, a helyi vállalkozók és a szervezett munkásság is hozzájárul a növekedési gépezethez.

Bár a növekedéspártiak hangsúlyozzák (sőt gyakran eltúlozzák) tevékenységük elönyeit, Logan és Molotoch eredményei azt mutatják, hogy a növekedés hatásai nem egyértelműen pozitívak: a munkaerőpiacon, a város költségvetésében vagy a környezeti állapotban negatív következményekkel járhat a növekedés túlhangsúlyozása (LoganMolotoch 1999).

A növekedési gépezet elmélet egy olyan strukturalista álláspontot képvisel, amely eltávolodik a megalkotói szerint a „neomarxistákra” jellemző egyszerüsítéstől, azaz a makrotényezők túlzott hangsúlyozásától, és érzékeny a különböző érdekcsoportok szerepére.

A hatalmi viszonyokat dinamikusabb kapcsolatként értelmezik, mint a „neomarxisták” - ezáltal megközelítésük azon késői konfliktuselméletekkel rokonítható, amelyek kísérletet tesznek az eltérő társadalomelméleti szemléletmódok (funkcionalizmus, konfliktuselméletek és szimbolikus interakcionizmus) ötvözésére.

\section{III.5.2. Posztmodern urbanizmus}

Az 1980-as évek végétől a társadalomtudományokban végbemenő kulturális fordulat következtében a településszociológiában és a társadalomföldrajzban egyaránt megerősödtek azok a nézetek, amelyek támadták a neomarxizmusra jellemző strukturalista szemléletmódot, hangsúlyozva, hogy annak kategóriái a modernista gondolkodás sajátosságait tükrözik. E fogalmak és felfogások a posztmodern megközelítéseket képviselök szerint érvényüket vesztették. Ilyen értelemben a posztmodern a korábbi megközelítések kritikáját adja azáltal, hogy a jelentések kulturális rendszerét helyezi előtérbe (Smith 2000, Dear 2001, Boros 2011). 
A humán ökológiához hasonlóan a posztmodern urbanizmus is az Egyesült Államokban született, ráadásul hasonló módon, egy adott nagyváros fejlődésére alapozva. Az irányzat képviselői szerint Los Angeles képviseli a városok jövőjét. Míg mintegy 80 évvel korábban Chicago testesítette meg a modern ipari nagyvárost, a 21. század elején Los Angeles és a dél-kaliforniai urbanizmus fejezi ki a városodási tendenciákat (Dear-Flusty 1998). A posztmodern városföldrajzban és városszociológiában egyaránt erősen érezhetően megjelenik Lefebvre tér termelésével kapcsolatos elmélete, amelyet továbbfejlesztve Soja $(1989,2001)$ azt vallja, hogy a térbeliség a posztmodern kultúra legfontosabb szervező elve, amely a rejtett hatalmi kapcsolatok és a globális kapitalizmus hatásainak kifejezője (Boros 2011).

A posztmodern urbanizmus elmélete azonban nem csupán Los Angelesre és környékére koncentrál, hanem általában a napjaink nagyvárosaiban végbemenő folyamatokra is. A várost formáló folyamatok többek közt a globalizáció, decentralizáció, fragmentáció, a posztfordista ipari termelés, és az etnikai sokszínűség, amely az identitások sokféleségével párosul. Jellemző továbbá a kisajátított terek megjelenése, terjedése, és a digitális, tudásalapú iparágak terjedése (Soja 2000).

A posztmodern város jellegzetessége a többek közt sokszínüsége, központ nélkülisége. Ezzel kapcsolatban Soja úgy fogalmaz, hogy egy társadalmilag és fizikailag egyaránt erősen fragmentált város jön létre. Az általa exopolisnak nevezett jelenség azt eredményezi, hogy a város „kivonul a városból” az egyes tevékenységek decentralizálódásával (Boros 2011). Míg Chicago az ipari termelés, a klasszikus kapitalista tőkeakkumuláció által létrehozott nagyváros volt, Los Angelest a rugalmas tőkeakkumuláció folyamatai formálják. Ennek eredményeképpen a dinamikus iparágak és a „kreatív gazdaság” által létrehozott high-tech agglomeráció jön létre. A Dear és Flusty (1998) által „keno kapitalizmusnak” nevezett folyamat eredményeképpen a város körüli edge city-k szerkezete és fő funkciója szinte véletlenszerüen változik (Boros 2011).

A kritikák rámutatnak, hogy bár a Kaliforniai Iskola modelljének alapjául szolgáló Los Angeles sajátos története miatt valóban fragmentált szerkezetü, ám egyáltalán nem igaz, hogy központ nélküli lenne, sőt jelenleg erős centralizációs törekvések jellemzik, illetve az edge city-k is megvalósítanak egyfajta központosulást, azaz már maga a modellként szolgáló város sem felel meg a modellben leírtaknak. Más kritikusok 
(Harvey 1989) úgy vélik, hogy a posztmodern kor valójában nem különbözik a korábbi időszakoktól, a változások csak a felszínt érintik, és továbbra is a tőke érdekei a meghatározóak (Boros 2011).

\section{III.6. A városantropológiai megközelítés}

Az 1960-as években kerültek a kulturális antropológia figyelmének előterébe a városi társadalmak és városok. A városantropológusok szemében a városok iránti érdeklődés megerősítette az antropológia hagyományos, a társadalmak és az emberi kultúrák változatossága felé irányuló figyelmét. A városantropológia magába foglalja a városok kulturális rendszerének vizsgálatát ugyanúgy, mint a városok kapcsolatát a nagyobb és kisebb területekhez és a populációhoz a világot átfogó városi rendszer részeként. A tudományág kiterjedése annak a felismerését tükrözi, hogy a hagyományos célcsoportok (törzs, parasztság) egyre inkább integrálódnak az urbanizált világba.

Módszereik között dominálnak: összehasonlító tanulmányok önálló közösségekről, multi-közösségekről, regionális kutatások, nemzeti szintü vizsgálatok, általános elméleti és módszertani tanulmányok. Kisebb tanulmányokban az egyének élettörténetére, vagy speciális társadalmi kontextusra, lakónegyedre és munkahelyre fókuszálnak (Fejö-Niedermüller 1988:48-59).

A társadalomtudományokban az 1980-as években kezdődött és az 1990-es években teljesedett ki az az elméleti fordulat, melynek hatására a társadalomföldrajzban is az antropológiai kultúraértelmezés terjedt el, amely kultúra alatt a közös értelmezéseket érti, és kulcsfontosságúnak tartja ezek megértését. Mindezek következtében a társadalomföldrajz minden területén új témák és megközelítések jelentek meg, amelyek a kultúrához kapcsolódva vizsgálják a jelenségeket. A kulturális fordulatot követően a megújuló „neomarxista” elemzések továbbra is az egyik legfontosabb részét jelentik napjaink városkutatásának (Knox-Pinch 2006, Boros 2011). 
III.7. Városgazdaságtani elmélet, a monocentrikus városmodell

A városok területhasználati módozatait, ezzel összefüggésben magát a település szerkezetét továbbá az ingatlanok kínálatának és keresletének jellemzőit, a városgazdaságtanban az Alonso által 1964-ben kidolgozott monocentrikus városmodellel vizsgálják. Alonso vizsgálata során arra törekedett, hogy a városi földterület kínálata és kereslete közötti térbeli egyensúly jellemzőit kimutassa (Alonso 1964). Az Alonso által kidolgozott monocentrikus városmodellt az utóbbi néhány évtizedben többen kiterjesztették. Lengyel Imre és Mozsár Ferenc szerint főleg Fujita, Henderson, Mills és Muth munkássága emelhető ki ennek kapcsán (Lengyel-Mozsár 2002). Az Alonso által kidolgozott modell lényege, hogy egy pontszerü piac létét feltételezve az ajánlati bérleti függvény bevezetésével, a háztartások és vállalkozások költségvetési egyenlete alapján megadja, hogyan formalizálhatóak a különböző szereplők döntései - kizárólag racionális döntést feltételezve - vagyis a döntés eredményeként a városi terület mely részén helyezkednek el a különböző költségvetésü háztartások és vállalatok.

$\mathrm{Az}$ Alonso-féle monocentrikus városmodell alaptétele, hogy a városi terület „szükös jószág” és egy adott területet csak egyetlen vállalat vagy háztartás bérelhet (birtokolhat).

A monocentrikus városmodellben a szereplök rendelkeznek egy a bérleti díjra vonatkozó ajánlati bérleti díj függvénnyel, ami megadja, hogy nulla profit feltételezése mellett, egy adott helyen lévő terület egységnyi részének használatáért mekkora összegü bérleti díjat képesek fizetni, beleértve a szállítási (közlekedési) költségeket is. Minél közelebb van egy terület a ,pontszerü piachoz” (városközponthoz), annál magasabb bérleti díjat hajlandóak és képesek ajánlani érte, mivel csökkennek a szállítási, illetve a munkába járási költségek. A monocentrikus modell tökéletes piacot feltételez, ahol minden szereplö árelfogadó, csak a költségei alapján kalkulál, és racionálisan dönt (Lengyel-Mozsár 2002).

\section{III.7.1. Externáliák, területhasználat és térbeli elkülönülés}

Az externália, extern hatás (külső gazdasági hatás) a közgazdaságtan egyik alapfogalma, mely azt fejezi ki, hogy a gazdasági szereplők tevékenysége azok számára is előnyöket illetve hátrányokat jelent, akikkel nem állnak üzleti vagy szomszédsági 
kapcsolatban. A városokban így keletkezhetnek negatív vagy pozitív extern hatások a különböző embercsoportok (gazdagok, szegények, fehérek, színes bőrűek, eltérő kultúrájú társadalmi csoportok stb.) között, de származhatnak extern hatások a közvetlen lakókörnyezet állapotából adódóan is, ami alapvetően maghatározhatja a különböző társadalmi rétegek térbeli elkülönülésének mintázatát is a városon belül (LengyelMozsár 2002).

A szegregáció folyamatát illetően ebben az elméleti megközelítésben kiemelt figyelmet érdemel a háztartások közötti externáliák modellezése a faji elöítéletek példáján (Kanemoto 1996).

A faji előítéletek városszerkezetre gyakorolt hatását a monocentrikus városmodell elméleti keretein belül az ún. határvonal-modellel (border model) vizsgálták. Ebben az alapfeltételezést a színes bőrủek és fehérek közötti teljes lakóhelyi szegregáció jelentette, továbbá az, hogy a különböző népcsoportok területi jelenléte extern hatást gyakorol egy másik népcsoportra az adott területen, ami befolyásolja a lakóhely megválasztását.

A modell elsőként abból a feltételezésből indult ki, hogyha a városközpontban színes bőrü családok élnek - általában kis alapterületü lakásokban, nagyobb családlétszámmal -, akkor az elöítéletek következtében a fehér családok a modell által meghatározott határvonaltól való nagyobb távolságra preferálják a lakóhelyválasztást. A másik feltételezés ennek az ellenkezőjére épült. Nevezetesen, hogy ha a centrumban fehérek, a külső zónákban pedig színes bőrüek laknak, akkor a fehérek felárat is hajlandóak fizetni a centrumon belüli ingatlanokért.

A modell alapján a faji elő́itélet mint externália elsősorban a fehéreket hozza rosszabb helyzetbe, mivel a határvonal közelében élők veszteséget szenvednek az extern hatás miatt, a távolabb élők pedig magasabb bérleti díjat fizetnek, mint amennyit fizetniük kellene abban az esetben, ha a faji előítélet nem jelentene negatív externáliát. A modell alapján levonható végkövetkeztetés az, hogy a szegregáció közgazdasági szempontok alapján is veszteséget okoz a társadalomnak, ezért a várospolitikának arra kell törekednie, hogy megszüntesse a faji előítéletekből származó elkülönülést (LengyelMozsár 2002). 


\section{HAZAI VÁROSKUTATÁSOK}

Az első magyar városszociológiai elemzések az 1900-as évek elején születtek, és hasonlóan a korai Nyugat-Európában végzett kutatásokhoz, kimondottan a városok negatív jelenségeivel, úgymint a nagyfokú lakásnyomorral és a munkásnegyedekben tapasztalható kirívó szegénységgel foglakoztak. E kutatások módszertanilag elsősorban statisztikai elemzésekre épültek és leginkább leíró jelleggel adtak képet a kor városi társadalmának problémáiról. „Az elemzések nem alapultak igazi szociológiai vizsgálatokon, s az empirikus tényeket nem kötötték a társadalom strukturális viszonyaihoz" (Szirmai 1994:16).

Az első, módszertanában is szociológiai megközelítésű kutatómunka Braun Róbert nevéhez köthető, aki a város és a falu problematikus jelenségeit is társadalmi összefüggésekben vizsgálta (Braun 1909).

Az első magyar városkutatók között említendő Éhen Gyula is, aki várostörténeti kutatásai mellett a városi társadalom legszegényebb rétegeit, így a segédmunkások, kisiparosok és kistisztviselők életét mutatta be (Éhen 1897, 1903, Szirmai 1994), ugyanakkor kortársa Ferenczi Imre kimondottan csak a munkások nyomorúságos lakásviszonyaival foglakozott (Ferenczi 1906; Szirmai 1994).

A magyar kutatók között Ágoston Péter neve is megemlítendő, aki konkrét elképzeléseket is megfogalmazott a feszültségek feloldására. Ezek a nyomornegyedek felszámolásának szükségességéről, a városok, városközpontok felújításáról, azoknak európai szintre emeléséről szólnak (Szirmai 1994).

Az 1920-as évektől a városszociológiai kutatások mellett a hazai faluszociológiai elemzések is megjelennek. Ezek kezdetben Szeged városához és vidékéhez köthetők. A szegedi szociográfusok azok, akik elsőként kezdik elemezni makrofolyamatok összefüggésében a magyar falu viszonyait. A kutatócsoport meghatározó egyénisége Erdei Ferenc, a történeti város- és faluszociológia kiemelkedő hazai művelője. Erdei véleménye szerint - Gideon Sjoberg és Leonard Riesman elméleti álláspontjához hasonlóan - a településstruktúra jellegét, alakulását döntő mértékben a konkrét társadalmi-történeti viszonyok határozzák meg. Ennek következtében a városok fejlődésének számos útja lehetséges (Erdei 1974a, 1974b) 
Az 1930-1940-es évek hazai városkutatásaira leginkább az irodalmi igényü szociográfiák a jellemzőek, úgymint Nagy Lajos (1932) és Jahn Ferenc (1937) müvei, a harmincas évek magyar városszociológiai kutatásai azonban már nagyobb mértékben támaszkodnak más tudományterületek kutatási eredményeire is.

Mendöl Tibor (1936) településföldrajzi elemzései arra mutatnak rá, hogy a város arculatát, építészeti sajátosságait, a munka- és lakóhelyek elhelyezkedését a topológiai viszonyok is meghatározzák.

A városszociológia humán ökológiai elmélete a 20-as évek végén Magyarországon is érezteti hatását. A statisztikai-demográfiai adatok alapján végzett hazai kutatások között Laky Dezső főként a főváros különböző társadalmi rétegeinek foglalkozási, demográfiai, jövedelmi, művelődési viszonyairól, és a város ökológiai-urbanisztikai szerkezetéről adott leírást (Laky 1929, 1930).

A magyar történészeknek is meghatározó szerepük volt a hazai városszociológia fellendítésében. Közülük Wildner Ödön munkássága különösen figyelemre méltó. Wildner történeti áttekintést adott a városok kialakulásáról, fejlődésük természeti és társadalmi feltételeiröl, majd szociológiai elemzést végzett a városbeli emberi kapcsolatokról, szomszédsági viszonyokról, a társadalmi felbomlás jelenségeiről és a városhoz való alkalmazkodás problémáiról (Wildner 1930).

A magyar településrendszer egy részének, az alföldi tanyás térségek vizsgálatának eredményeképpen a magyar városok kialakulásának más nézöpontú megközelítését adta Erdei Ferenc (1971, 1974b), amikor úgy ítélte meg, hogy a város nem az azt körülvevő vidék kiemelkedő szigete, sokkal inkább annak szerves része, kiszolgálója.

Erdei „csillagrendszer-modellje” a különböző településtípusok funkcionális együttmüködését a bolygórendszerekhez hasonlítja, melynek lényege, hogy a kisebb települések (holdak) mindegyike egy-egy nagyobb város (bolygók) vonzáskörzetéhez tartozik. A kiegyensúlyozott müködés feltétele a vonzáskörzeten belüli funkcionális együttmüködés társadalmi-gazdasági és szolgáltatási területen egyaránt (Erdei 1971, 1974b).

A magyarországi városfejlődéssel kapcsolatosan az 1980-as években Enyedi György a magyar településfejlődés nemzetközi folyamatokhoz viszonyított 
megkésettségére hívja fel a figyelmet (Enyedi 2004:15). Megállapítja, hogy az általa a modern urbanizáció első szakaszának nevezett városrobbanás hazánkban két részre szakadva zajlott és hosszan elhúzódott. Az első városrobbanási hullám Enyedi szerint az 1860-as éveket követően zajlott le az iparosodás eredményeképp. Ez azonban javarészt csak a fővárosban volt érezhető, a vidéki városok nagy része továbbra is mezőváros maradt. Ezt az időszakot egy hosszú stagnálás követi. A városrobbanás szakaszának második üteme az 1950-60-as évek extenzív szocialista iparosításához kötődik. Ennek a túlzott iparosításnak a hatási azonban már arányosabban jelentkeznek a településhálózatban, ugyanakkor a társadalmi szerkezetet mélyebben érinti, és legfőképp a strukturális mobilitás területén jól kimutatható (Enyedi 1988). A változások a falun lakó népességet lakóhelyének elhagyására késztetik, főképpen az iparosítás kezdeti extenzív szakaszában. Ezzel párhuzamosan azonban nem történnek meg a városokban a szükséges infrastrukturális fejlesztések, így a tömeges városba költözésnek jelentős akadályai vannak. Az 1960-as években a mezőgazdaság korszerüsítése is megkezdődik, majd a hetvenes években a termelőerők állami irányítás mellett megvalósuló tudatos és tervszerü dekoncentrációja, a vidék iparosítása következtében a magyar városfejlődés a relatív dekoncentráció szakaszába lép: megjelennek a városi agglomerációk, differenciálódás megy végbe a vidéki településállományban (Enyedi 2004:15-24), s azóta is a városi népesség csökkenése figyelhető meg (Szirmai 1998: 181).

Konrád György és Szelényi Iván ezt a jelenséget nevezi késleltetett városfejlődésnek (Konrád-Szelényi 2004.). Magyarázatát abban látják, hogy a második városrobbanási szakaszban a siettetett iparosítás kap túlzott hangsúlyt a gazdaság fejlesztésében, háttérbe szorítva az infrastrukturális fejlesztéseket. Megítélésük szerint bizonyos fajta alulurbanizáltság alakul ki a városok lakásállományának nem megfelelő mértékü növekedése miatt. Ez egyebek mellett a környező településekről a városokba dolgozni járó rétegek növekedését, a saját erőből való lakásépítés kényszerét, és a városi funkciók kiteljesedésének visszásságát eredményezi (Szirmai 1994). 
IV.1. Az ökológiai-társadalmi viszonyokat meghatározó mechanizmusok

A hazai városkutatások történetében a 70-es évektől kezdődően a szociológiai kutatások terén egy felfelé ívelő szakasz veszi kezdetét. Az ebben az időszakban végzett kutatások eredményei rámutatnak arra, hogy a történeti hatások, a spontán társadalmi, gazdasági folyamatok mellett már a korábbi századok tudatos várostervezési várospolitikai beavatkozásai szerepet játszottak a városi területi egyenlőtlenségek kialakulásában, a társadalmi csoportok városi térben történő elhelyezkedésében. Csanádi Gábor és Ladányi János felhívja a figyelmet arra a tényre, hogy Budapest esetében a kiegyezés időszakának tudatos várospolitikai koncepciója különösen fontos a térbeli társadalmi egyenlőtlenségek kialakulásának szempontjából. Az 1870-ben megalakított Fővárosi Közmunkák Tanácsa fejlesztési programja egyértelműen tartalmazza azokat az elveket, amelyek a város szegregált területi rendszerét is megalapozzák. A város központi építési övezetekre való felosztása, a beépítés jellegének, a teleknagyságnak, az építhető házak magasságának, a házfalak anyagának övezetenkénti szabályozásai a mai szegregációs folyamatok szempontjából is döntő jelentőségüek (Csanádi-Ladányi 1992).

Szelényi Iván kutatásai rámutatnak arra, hogy a hazai nagyvárosok ökológiai szerkezete a fö tendenciák tekintetében tipikusnak mondható. A történelmi belvárost környezi az átmeneti övezet, amely a belváros és a peremkerületek között elhelyezkedő vegyes beépítésü, lakóhelyi funkciókat, illetve egyéb funkciókat is betöltő terület. Ezt követi a vegyes ipari lakóterületek övezete.

A külső lakóterületi gyürü következik ezután, amely részint a város korábbi belső fejlődése során keletkezett családi házas telepekből, részint a közigazgatásilag hozzá csatolt települések, település-együttesek kertes, családi házas egységeiből szerveződött. Az új lakótelepek ebbe a gyürúbe ékelődnek (Szelényi 1990). 


\section{IV.2. Az új lakótelepek szociológiai problémái}

Az új lakótelepek felépülésével kezdődő problémák elsősorban az új konstrukciók belső viszonyaival, az infrastrukturális ellátottsággal, az épített környezettel, de főleg a lakások méreteivel kapcsolatban merülnek fel. A kritikák szerint a lakások méretei túlságosan standardizáltak, többnyire kicsinyek, és nem alkalmazkodnak sem a különböző társadalmi elvárásokhoz, sem a családok nagyságához. Szelényi és Konrád ezzel kapcsolatos kutatásai arra világítanak rá, hogy az új városrészekkel összefüggő problémák mögött alapvetően a lakáspiac hiánya, főleg a szakképzettebb, iskolázottabb társadalmi rétegeknek az állami lakáselosztáson keresztül kielégíthetetlen elvárásai húzódtak meg. A szakképzetlenebb társadalmi csoportok elégedettebbek voltak az új városrészekkel és az új lakásokkal is, míg magasabb státuszúak kevésbé.

A problémák másik köre a redisztribúciós lakáselosztási viszonyokkal függött össze. Egyre nyilvánvalóbbá váltak a társadalmilag kedvezőtlen helyzetben lévő, főként munkásrétegek hátrányai a centralizált lakáselosztási rendszerben. A szociológiai kutatások igen hamar egyértelművé tették, hogy az első új lakótelep-fejlesztési hullámban épült városrészek főleg a társadalom magasan kvalifikált, vezető beosztású és szakértelmiségi rétegeinek, többgyerekes, fiatal családoknak a lakóhelyei. Megállapítják, hogy az új lakótelepek egyfajta szuburbanizációs folyamatot indítottak el, mégpedig olyan irányban, hogy a 70-es években a leromlott belső városrészek tehetősebb társadalmi rétegei mintegy kivonultak a városok szélén felépült új lakótelepekre. Az első lakótelepi sávok tehát a belvárosi részek szakképzettebb társadalmi rétegeiből szerveződnek. Ez a csoport azonban nem ökológiai okok miatt megy az új negyedekbe, hanem azért, mert azt az épített környezetet és lakást tartották maguk számára kívánatosnak (Szelényi-Konrád 1969, Szelényi 1972).

\section{IV.3. A magyar városok belső tagozódása}

Városainkban a népesség belső tagozódására az egyik legmarkánsabb hatást gyakorló tényező a szocialista városok jellegzetes fejlődési modellje, melynek következtében kialakult a város sajátos kelet-európai formája, amit Szirmai Viktóra (1988) „csinált” városoknak, ill. „új” városoknak nevez. Ennek a várostípusnak a 
kialakulásához vezető fő ok a termelési eszközök magántulajdonának megszüntetése, ami jelentős hatást gyakorol az urbanizáció és a városszerkezet alakulására egyaránt utóbbira kifejezetten annak révén, hogy elkezdődnek a városközpontok felújításai, valamint gyorsan szaporodnak az új építésű lakótelepek (Szelényi 1971:5).

A magyarországi városok belső struktúrája - így Szegedé is - még a II. Világháború előtt kialakul, és azzal a minden európai országban tendencia szintjén megfigyelhető tulajdonsággal jellemezhető, hogy a városban lakó népesség társadalmi státusa ebben az időszakban még a városközpontban a legmagasabb, és a szélső területek felé haladva fokozatosan csökken. A szocialista városfejlesztés szélesebb körü kibontakozásával a különbségek némi mérséklődése figyelhető meg. Mindez ellenkező folyamat az Amerikai Egyesült Államokban és Kanadában található városok domináns társadalmi-ökológiai elrendeződésével, ahol a belső városrészekben lakók szociális elismertsége a legalacsonyabb, a kertvárosban élőké pedig a legmagasabb (Szelényi 1971:16-17).

Nagyvárosaink belső tagozódásának formáiról Konrád György és Szelényi Iván 1968-ban Pécsen és Szegeden végzett kutatásai alapján alkothatunk képet (Szelényi 1990.). Mindkét vizsgált város a belvárosát akkoriban az átmeneti övezet vette körül, melynek területén a városmag és a peremkerületek által határolt vegyes beépítésü, a lakóhelyi funkciók mellett más feladatokat is ellátó zóna volt. Ezen belül megkülönböztetik egyrészről a jó (átmeneti övezet I.), másrészről a gyengébb, földszintes, falusias jellegü (átmeneti övezet II.) házakkal beépített területeket. A második fajta átmeneti övezet lakásállományához hasonló területet képvisel a következő övezet (ipari lakóterület).

A külső lakóterületi gyürü szintén több részre osztható: fellelhetők itt kertes házas telepek (ezeken belül is elkülöníthetők az igényesebb épületeket felvonultató és az inkább falusias jellegü épületekből álló területek), a várossal időközben összenövő családi házas volt települések, valamint az új lakótelepek.

A városszerkezet átalakulásának dinamikájával kapcsolatban megfogalmazódik az az elképzelés is, hogy a szocialista városfejlesztés hatására lehetőség nyílhat az egyes területek, övezetek közötti különbségek felszámolására, mérséklésére. Ez azonban nem így történik, sőt egy olyan irányú folyamat veszi kezdetét, melynek következtében a társadalmi státusz a városmagban és a lakótelepi gyürüben megemelkedik, a két övezet 
közötti átmeneti zónában pedig lecsökken, s ugyancsak alacsonnyá válik a lakótelepi gyürün túl, ami az addig folyamatosan csökkenő görbének hullámzó alakot kölcsönöz (Szelényi 1971:20).

A rendszerváltást követően a városok társadalmának életében megfigyelhető változások egyik markáns jellemzője a szuburbanizáció, amely elsősorban azon társadalmi rétegekre jellemző, akik - mint például a korábbi kommunista technokrácia, az értelmiségi elit, valamint az új vállalkozók egy része - sikeresen tudják vagyonukat oly mértékben növelni, hogy megengedhetik maguknak a kertvárosi otthont, $\mathrm{s}$ az azzal együtt járó ingázáshoz szükséges két gépkocsi fenntartását (Ladányi-Szelényi 1998:69).

$\mathrm{Az}$ átalakulást kísérő másik, az egész posztszocialista Közép-Európában érzékelhető változás a társadalmi polarizáció, amely a városokban nagymértékben összekapcsolódik a térbeni szegregáció jelenségével: egyes kutatók szerint a rétegződési struktúrában a rendszerváltás után a növekvő egyenlőtlenségek az idősek és a szegény rétegek magasabb fokú térbeli elkülönüléséhez vezetnek (Weclawowicz 1998:55-62).

\section{IV.4. A lakás mint a társadalmi egyenlőtlenség kifejeződésének eszköze}

A városok társadalma térbeli eloszlásának vizsgálatakor egy másik lényeges tényező a lakáskérdés: ,, városaink ökológiai szerkezetének átalakulásában feltehetően a tömeges lakótelep-épitkezés játssza a legnagyobb szerepet” (Szelényi 1971:25).

A témában megfogalmazott elméletek legfőbb kérdése, hogy az állami szerepvállalás milyen mértékben járul hozzá a magyarországi lakáshelyzet, városkép kialakulásához továbbá, hogy ezt hogyan alakítja a korlátok között müködő piaci logika.

Az egyik állítás az, hogy a szocialista társadalmakban a különböző városi övezetek nem a klasszikus módon alakulnak ki (Szelényi 1990). Ennek az oka az elmúlt évtizedek sajátos eszmerendszerében, gazdaságpolitikájában keresendő. Szelényi szerint ez a politikai rendszer más módon reagált a lakásproblémára (ami a világon egyébként mindenütt jelen volt). A lakásprobléma kettős jellegü: egyrészről beszélhetünk lakáshiányról, másrészről társadalmi elosztási nehézségről, vagyis a lakásprobléma mint társadalmi egyenlőtlenségi probléma jelenik meg. A helyzet megoldásához az állami redisztribúció és a piac is hozzájárul a maga eszközeivel. 
A lakásszociológia nézőpontja szerint a lakásrendszer, a lakásviszonyok a társadalmi élet megannyi aspektusát tükrözik: kifejeződésre jut bennük az emberi társulások fejlettsége, termelőképessége, evolúciója, az adott közösség munkarendszere, a társadalom életfeltételei, a kulturális értékek, de megtestesül általa családtípus is (Duric 1971:301-303). Mégis a szociológiai kutatások szempontjából a leglényegesebb szempont az, hogy a lakásállomány differenciálódása hogyan befolyásolja a társadalmi rétegek helyzetét (Konrád-Szelényi 1971:345). Az egyes társadalmi csoportok pozíciója és lakáshelyzetük közötti összefüggést fejezi ki a lakásosztály fogalma, amely nagyjából azonos piaci helyzetű lakásokat és a lakásrendszeren belüli osztálypozíciót jelent (Csizmady 2003:31-33).

A lakáshelyzet és a társadalmi rétegződés közötti kapcsolat a lakáspolitika, a lakáshoz való hozzájutás mechanizmusainak elemzésével magyarázható (Szelényi 1972). A lakásszociológia a filtráció fogalmával jelöli a különböző társadalmi rétegeknek az egyes lakástípusok között megfigyelhető mozgását (Szelényi 1971:345), amelynek piaci alapokon való müködése esetén a társadalmi rétegek azonos ütemü, felfelé irányuló filtrációja valósul meg.

A Hegedüs József, Tosics Iván és Szelényi Iván közötti vita a kelet-európai lakásmodell értelmezésével kapcsolatosan, pontosabban ennek a részpiacnak az értelmezése körül bontakozik ki. Szelényi elmélete ezt a szektort alapjában piacinak tekinti, és ennek alapján következtet a ,piacnak” mint másodlagos mechanizmusnak a lakás-egyenlőtlenségekre való hatására. Hegedűs és Tosics állítása ezzel szemben az, hogy a kelet-európai lakásrendszerben a magán-lakásépítés - a saját kivitelezésben megvalósult ún. kalákás építkezés - olyan gazdasági környezetben valósul meg, amely fékezi és semlegesíti a piaci hatásokat (Hegedűs-Tosics 1988).

Hegedüs és Tosics szerint ebben a fogalmi keretben tömören jellemezhető a három lakásmodell típus: a nyugat-európai, az észak-amerikai, és a kelet-európai. Mind a nyugat-európai, mind pedig az észak-amerikai modellnek domináns eleme a magánszektor és piaci mechanizmus („B szféra”), a két modell alapvetően a közösségi lakásállomány nagyságában különbözik: a nyugat-európai rendszerekben hagyományosan nagyobb arányú a közösségi szektor. A kelet-európai modellben az állami/nonprofit szektor és nem piaci mechanizmus („C szféra”) dominál, ugyanakkor az 
ettől eltávolodó magyar lakásrendszerben (1980-as évek) megjelenik a szük piaci és az egyre bővülő nem piaci magánszektor („D szféra”).

Az alapkérdés, hogy milyen irányban alakul át a kelet-európai modell: a nyugateurópai, a közösségi szektorra jobban építő modell, vagy pedig az észak-amerikai modell irányába. Hipotézisük szerint az átmenetben jelentős társadalmi és politikai erők lassítják az átalakulást, és inkább egy ,új” modell irányába hatnak, amelyben a nem piaci magánszektor játszik domináns szerepet (Hegedüs-Tosics 1998).

\section{IV.5. A szegregáció kutatása Magyarországon}

A szegregáció a társadalmi rétegek térbeli elkülönülése, meghatározott városrészek társadalmi struktúráján belül egy-egy réteg városi arányához képest mérhető túlsúlya. A szegregáció a lakóhelyi és az életkörülmények szintkülönbségét, társadalmi hátrányokat jelent, mert fokozza a társadalmi-strukturális helyzetből adódó különbségeket. A szegregáció főleg az alacsonyabban iskolázottakat és szakképzetleneket szorítja periférikus élethelyzetbe.

A hatvanas évek végén lebonyolított városszociológiai kutatásokból kiderült, hogy Pécs és Szeged fizikai értelemben eltérő övezeteinek eltérő a társadalmi összetétele is: a szakképzettebb társadalmi csoportok magasabb arányban élnek a jobb színvonalú övezetben, míg a szakképzetlenebbek nagyobb arányban jelennek meg az alacsonyabb színvonalú részeken. (Szelényi 1990:114). Hasonló folyamatok derülnek ki a Salgótarjánban, Veszprémben, Miskolcon, Debrecenben, Dunaújvárosban végzett vizsgálatokból is (Béres 1983, Saád 1977; Szirmai 1988a, 1988b).

Elsősorban Budapesten végzett empirikus kutatásai során Ladányi János és Csanádi Gábor számos eredménnyel járultak hozzá a városi szegregáció kutatásához és értelmezéséhez.

Egyrészt rámutattak arra, hogy vizsgálataik során a klasszikus városszociológiai elméletek övezeti felosztását alkalmazva csupán korlátozottan, sok esetben egyáltalán nem sikerült megbízható képet alkotni a város társadalmának térbeni elkülönüléséröl. Ennek fö oka szerintük az, hogy az ökológiai szemlélet alkalmazói modelljeiket:

- szabályszerü geometriai formákból

- szabálytalan geometriai formákból, de területileg még összefüggő alakzatokból 
- szabálytalan formájú és területileg sem összefüggő, azonban mindenképpen kevés számú, nagy területi egységekből álló alkotórészekből építik fel (Csanádi-Ladányi 1988:1-2).

Ezen eltérő léptékű területi csoportosítások révén nyert aggregátumokról (övezet, szektor, területi rendszer) ugyanis bebizonyosodott, hogy azok heterogének, bennük a társadalmi rétegek szempontjából szükségszerüen további homogén területek különíthetők el. Arra azonban megfelelőek, hogy a város fizikai szerkezetét (házak milyensége, házanként hány lakó található) bemutassák. Azt is megerősítik, hogy az övezetes városszerkezet nyomai azokon a helyeken mutathatók ki a leghatásosabban, ahol erősen érződik a kontrollált várostervezés.

Végső konklúziójukban megfogalmazzák, hogy lényegében maga a klasszikus humán ökológiai tradíció szorul felülvizsgálatra, helyette a történeti-szociológiai megközelítést és a sok terepmunkát javasolják a szegregáció kutatásához (CsanádiLadányi 1988:11-12).

\section{A TÁRSADALMI-TÉRBELI ELKÜLÖNÜLÉS VIZSGÁLATÁNAK FÖBB MÓDSZEREI}

A városrészek közötti különbségek számszerüsítésére, mérésére több kísérlet történik, ugyanis a területi tervezés szempontjából lényeges, hogy a kisebb területi egységek összehasonlíthatóak legyenek, és meghatározható legyen az eltérés mértéke.

A városok térszerkezetét vizsgáló kutatások során az 1950-es években E. Shevky és W. Bell alkalmazza először a társadalmi téranalízisnek nevezett eljárást. A vizsgálat során a város lakóinak társadalmi, vagyoni helyzetére, családi állapotára valamint etnikai státuszára úgy tekintenek, mint a társadalmat alakító tényezőkre. A Shevky és Bell által kidolgozott társadalmi téranalízis egy osztályozási mintát ad a városrendezési körzetek csoportosításához.

Három faktort határoznak meg: a társadalmi helyzetet, a családi-vagyoni állapotot és az etnikai státuszt. Shevky és Bell álláspontja az, hogy a társadalmi helyzet az egyének és egy-egy kisebb társadalmi csoport döntéseinek kapcsolatrendszere miatt fontos, ugyanis az egyének által meghozott önálló döntések meghatározzák a társadalomban elfoglalt pozíciót. Ennek jellemzésére a foglalkoztatási és képzettségi mutatók alapján képeznek egy tényezőt. A családi és vagyoni állapotot kifejező 
faktorban három mutatót vesznek figyelembe: a termékenységi arányszámot, a női foglalkoztatottak arányát és a családi házak arányát az épületállományon belül. Ezek a mutatók tartalmazzák a társadalom prosperitását, a családstruktúrát valamint a társadalom vagyoni helyzetét. Harmadik faktorként a szegregációt veszik alapul, mint a döntési mechanizmusokban szintén szerepet játszó tényezőt (Shevky-Bell 1961/1974).

A területi összehasonlító vizsgálatok során a jövedelemeloszlás egyenlőtlenségére gyakran használják a Gini-együtthatót, amely egy szóródási típusú egyenlötlenségi mutató, ami a népességi arány és a jövedelmi arány viszonyát méri. Értéke a jövedelmek teljes egyenlősége esetén nullával egyenlő, a teljes egyenlőtlenség (amikor minden jövedelem egy kézben összpontosul) esetén az értéke egy(Németh 2005).

A kisebb területegységek összehasonlítására a deprivációs index, illetve a többszörös deprivációs index alkalmazható, amelyeket leginkább a területi tervezésben használnak.

A többszörös deprivációs index hét dimenziót tartalmaz:

1. a jövedelem

2. a foglalkoztatottság

3. az egészségügy és fogyatékosság

4. a képzettség és iskolázottság

5. a földrajzi elérhetőség

6. a szociális környeze,

7. a lakáshelyzet, és a biztonság

Az egyes dimenziók további aldimenziókra is oszthatók, például a lakáshelyzet a „belső” (a lakás komfortfokozata) és „külső” lakáshelyzettel (lakókörnyezet) is mérhető. Minden dimenzió és aldimenzió több mutatót tartalmaz (Nemes Nagy: 2005). A dimenziók és a hozzájuk tartozó változók kiválasztása után valamilyen adattömörítési eljárást szoktak alkalmazni a deprivációs indexek megalkotásához - leggyakrabban faktor illetve fökomponens-elemzést. (Fahey 2005, Whelan-Layte-Maitre 2005) 
A szegregáció-kutatások szociológiában leginkább használatos módszerei a disszimilaritási index és a szegregációs index számítások. A disszimilaritási index két társadalmi csoport térbeli elkülönülését méri. A számítás lényege abban áll, hogy két kiválasztott csoport területegységek szerinti százalékos megoszlásai területegységenkénti különbségeinek abszolút értékeit összegzik, és osztják kettővel (Duncan-Duncan 1973, 2000, Csanádi-Ladányi 1992:94 idézi Csizmady 2003, Németh 2005). Az index értéke 0 és 100 között mozoghat - a teljesen szegregációmentes állapotban az alsó határérték felé mutat, míg a teljes elkülönülés esetén a felső irányába mozdul el (Cséfalvay 1994).

„Szokás az indexet olyan módon is értelmezni, mint azoknak a részarányát, akiknek más területegységekben kellene lakniuk ahhoz, hogy a két megoszlás egyenletes legyen. Abban az esetben, ha a két vizsgált megoszlás a sokaság két kiemelt csoportjára vonatkozik, disszimilaritási indexröl, abban az esetben pedig, amikor egy kiemelt csoportot az összes többi csoport eloszlásával vetünk egybe, szegregációs indexröl beszélünk” (Duncan-Duncan 1973, 2000, Csanádi-Ladányi 1992:94 idézi Csizmady 2003; Németh 2005;).

A szegregációs index a disszimilaritási indexből is számítható, amely egy társadalmi csoport térbeli elkülönülését mutatja meg a többi csoporthoz képest. (DuncanDuncan 1973:185, Kovács 2002)

Csanádi és Ladányi a cigányok 1987-es budapesti szegregációjának vizsgálatakor az általános iskolák által készített statisztikai beszámolók alapján először két csoportba sorolta a budapesti iskolákat, majd azon iskolák mindegyikében, ahová az iskolai statisztika alapján cigány gyerekek jártak terepmunkát végeztek az alsó tagozatos osztályokban.

Azok közül az iskolák közül, ahová a statiszták szerint nem jártak cigány gyerekek, egy 10\%-os kontroll mintát vettek és ezen a mintán is elvégezték az összeírást. A két minta összevetése megerősítette azt a feltételezést, hogy az iskolai statisztika jól tükrözi a valós helyzetet. Az összeírás eredményeképp 3899 gyerek adatait írták össze, majd egy igen részletes 1200 szelvényt tartalmazó térképen ábrázolták a roma családok elhelyezkedését. A módszert Ladányiék pontozásos módszernek nevezték el, amelynek 
során nemcsak a szegregáció városrendezési körzetenkénti eloszlásának ábrázolására van lehetőség, hanem az ennél kisebb egységek csomósodási pontjainak megragadására is (Ladányi, 2008:62-78).

A társadalmi egyenlőtlenségek területi vizsgálatának módszertani problémáira Ladányi János, Tosics Iván és Hegedűs József kutatásai hívták fel a figyelmet. Budapesten végzett vizsgálataik során különböző nagyságú területi aggregátumok szerint vizsgálták azt, hogy a társadalmi különbségeket meghatározó egyes paraméterek szórása területi egységenként milyen mértékü magyarázó erővel bír a területi elkülönülést illetően (Ekler-Hegedűs-Tosics 1980, Csanádi-Ladányi 1988, Ladányi 2008).

\section{A TÁRSADALMI-TÉRBELI ELKÜLÖNÜLÉST VIZSGÁLÓ KUTATÁSOK SZEGEDEN}

A társadalmi rétegződés és térbeli elkülönülés szociológiai szempontú vizsgálata Szeged terültére vonatkozóan elöször az 1960-as évek végén zajlik, Szelényi Iván és Konrád György vezetésével. A kutatás statisztikai adatok elemzésével készül, és rávilágít arra, hogy Szeged fizikai értelemben eltérő övezeteinek eltérő a társadalmi összetétele is: a szakképzettebb társadalmi- csoportok magasabb arányban élnek a jobb színvonalú övezetekben, míg a szakképzetlenebbek nagyobb arányban jelennek meg az alacsonyabb színvonalú részeken. A városfejlődési folyamatok vizsgálatának eredményeként Szelényi szerint ebben az időszakban Szeged fejlődése sokkal organikusabb, mint pl. Pécsé, mivel a csongrádi megyeszékhelyen már a 19. század végén olyan városközpont alakult ki, amely képes egy száz-kétszázezres lélekszámú település központjaként funkcionálni (Szelényi 1990).

Szelényiék a várost urbanisztikailag nagyjából egységes övezetekre osztják az alábbiak szerint: városmag a (1) belváros, amelyet körülvesz az átmeneti övezet két szakasza, a (2) leromló, avuló és a (3) zöldövezeti, színvonalas szakasz, az (4) ipari lakótelep, a (5) külső gyürüben lévő családi házas telepek, és az (6) új lakótelep. Az övezetek tulajdonságait a kutatás eredménye alapján három tényező szabja meg: a lakásosztály szerinti összetétel, funkcionális jellemzőik és a történeti egységük. 
Szelényiék Szeged városi övezeteire vonatkozóan megállapítják, hogy infrastrukturális szempontból fejlettnek tekinthető a (1) belváros, a (3) javuló átmeneti zöldövezet és az (ekkor még) (6) új lakótelep. Ezeken a területeken él a magasabb társadalmi státuszú népesség 40 százaléka (szellemi foglalkozásúak, vezető beosztásúak stb.). A másik három övezet, ahol a kutatás idején a szegediek többsége lakik, infrastrukturálisan fejletlen terület. Az alacsony fejlettségi szintü területeken 70 százalékban a fizikai foglalkozásúak lakóhelyei találhatóak, amelyek igazolják az övezetek közti társadalmi szegregációt. Szelényiék megállapíják, hogy a városban addig lezajlott migrációs folyamatok nem csökkentették az elkülönülést, hanem a lakáspolitika révén éppen erösítették, vagyis tovább fokozták a különböző társadalmi rétegek térbeli elkülönülését. A magasabb státusúak ebben az időszakban új lakótelepi lakásokhoz jutnak, míg a fizikai dolgozók és a munkáscsaládok a külső családi házas övezetekben és a leromló átmeneti övezetekbe szorulnak ki, ezzel egy idöben a már avuló átmeneti övezet és az ipari lakótelepek további leromlását siettetve (Szelényi 1990).

Az 1980-as népszámlálás alapján a statisztikai hivatal szakemberei Szegedet kilenc építészetileg és funkcionálisan elkülönülö részre osztják. A 80-as évektől kezdve leginkább e területi felosztás alapján történnek az elemzések a város társadalmi-területi különbségeit vizsgáló, leggyakrabban a KSH népszámlálási adataira kiterjedő elemzésekben. Az elhatárolt egységek nagy különbségeket mutatnak a beépítettség, a laksürüség, a fejlődés iránya, a lakosság foglalkozása, korstruktúrája, lakásviszonyai stb. tekintetében (KSH 1983).

Az 1990-es és 2001-es népszámláláskor az adatokat a funkcionális tagozódás mellett, már az úgynevezett városrendezési körzetekre vonatkozóan is kódolták, és elemzések születtek ebben a területi bontásban is.

A funkcionális kategóriák alkalmazásának egyik előnye, hogy nem koncentrikus körök szerinti, „szervetlen” övezeteket határolnak le, hanem tekintettel vannak egy-egy környék építészeti, geográfiai és térhasználati jellegzetességeire is.(Kovács 2003)

2003-tól folyamatosan végzünk Szegeden településszociológiai kutatásokat, kvalitatív és kvantitatív módszerrel, valamint a két módszer ötvözésének technikájával 
egyaránt (Rácz 2007, 2009, 2011). Ebben a kutatássorozatban a Szegeden belüli területitársadalmi elkülönülést vizsgáló elemzés során Balogh Péter a különböző társadalmi csoportok területi eloszlásában tapasztalható különbségeket a Duncan házaspár (1973) által kidolgozott disszimilaritási indexszel mérte (Balogh 2007). A Szeged Studies 2003 adatállományában végzett elemzéseinek eredményei azt támasztják alá, hogy a nagy területi egységekben (funkcionális lakóövezetek) nem mutatható ki sem nominális (nem, etnikum, családi állapot), sem pedig graduális paraméterek szerinti (életkor) éles társadalmi elkülönülés Szegeden. Az elemzés ugyanakkor rámutat arra is, hogy a nagy területi egységekre jellemző társadalmi heterogenitás mellett érezhetőek bizonyos paraméterek szerinti területi különbözőségek is. Az iskolai végzettség esetében például kimutatható, hogy a belvárostól és a villanegyedtől kifelé haladva csökken az elvégzett iskolai osztályok számának átlaga. Szorosan követi a központi övezetet a diplomások arányában a belső lakóterület is, de itt már inkább az érettségizettek dominálnak, ahogy a kertvárosi lakóövezetben is. Szakmunkás végzettségüeket leggyakrabban a lakótelepeken és a falusias lakóövezetben találunk, ahogy a legfeljebb nyolc osztállyal rendelkezőket is (leginkább Kiskundorozsmán és Szentmihálytelken).

A 2003-ban készült adatfelvétel szerint a fizikai munkások - ide értve a szakmunkásokat a szakképzetleneket és a gazdálkodókat - föként a falusias lakóövezetben (Kiskundorozsma, Szentmihálytelek, Szőreg, Tápé), illetve a lakótelepeken (Tarján) vannak jelen nagyobb arányban, a nem fizikai foglalkozásúak többsége pedig a belvárosban, a villanegyedben és a belső lakóterületen (Alsóváros, Felsőváros, Móraváros, Újszeged) él. A felső- és középvezetők, diplomás foglalkozásúak és a kereskedők, szolgáltatók többsége ezeken a területeken lakik. Az egyéb szellemi foglalkozásúak és az alsóvezetők lakhelyei többé-kevésbé arányosan megoszlanak a belső lakóterület, a kertvárosi lakóterület, a lakótelepek és a falusias lakóterület között (Balogh 2007).

A 2003-as adatok a jövedelmi helyzetet illetően is hasonló tendenciát mutatnak. A falusias lakóövezetben, illetve a lakótelepeken találjuk a legtöbb alsó jövedelmi helyzetü és a legkevesebb magas jövedelmű szegedit. Ez utóbbiak jellemzően a belvárosban és a villanegyedben laknak. Az említett tendenciát jól illusztrálja, hogy az előbbi két területi kategóriában a legmagasabb a jó jövedelmi helyzetủek aránya, némileg kevesebb a belső lakóterületen, majd a lakótelepeken és a kertvárosi lakóövezetben, végül a falusias 
lakóövezetben. A jövedelem a központi területektől haladva csökken a periféria irányába.

A lakókörülmények valamelyest módosítanak a centrum-periféria irányon, ugyanis a belváros által mutatott középérték megegyezik a falusias lakóövezetével és a lakótelepekével, vagyis az itt lakók inkább közepes lakásfeltételekkel rendelkeznek. Jó körülményeket a belső és kertvárosi lakóövezetben illetve a villanegyedben találhatunk. A lakáshelyzet és a lakókörülények vizsgálata során Balogh a legfeljebb nyolc osztályt végzettek, a gazdálkodók, szakképzetlenek és a rossz lakókörülmények között talált összefüggést. Hasonló eredményre jutott a diplomások, felsővezetők, a diplomához kötött foglalkozásúak, a kereskedők, szolgáltatók és a jó lakókörülmények között. Középen helyezkednek el a szakmunkás végzettségűek, illetve az egyéb szellemi foglalkozásúak és az iparosok, szakmunkások. (Balogh 2007).

A Balogh által az iskolai évek számából, a jövedelmi decilisekből és a lakókörülményeket mérő változókból konstruált szocioökonómiai státuszindex alapján ismét egyfajta középpontból kifelé irányuló lejtő rajzolódik ki Szegeden 2003-ban. A Villanegyed és a Belváros lakóinak fele a felsőközép és felső kategóriából kerül ki. Újfent középen találjuk a belső és a kertvárosi lakóövezetet és a lakótelepeket. A falusias lakóövezet esetében az alsóközép státuszúak tekinthetők jellegadónak.

A szegedi városkutatási projektet 2007-től kezdődően egy mentális térképes vizsgálattal is bővítettük. A kutatási irányvonalat abban jelöltük meg, hogy milyen hasonlóságok és különbségek fedezhetőek fel a területi-társadalmi elkülönülés valós és mentális mintázatai között.

Az ilyen irányú vizsgálódás első eredményeit 2009-ben publikáltuk (Rácz 2009) Ferencz Gábor tanulmányában (Ferencz 2011), ahol a társadalmi státuszok közti viszonyrendszert ugyancsak a disszimilaritás és szegregáció kiszámításával vizsgálta. Ferencz mind a munkajelleg-csoportok, mind pedig a státuszkategóriák esetében ugyanazokat a főbb jellemzőket találta Szegeden:

Az egymástól legtávolabb lévő csoportok (kvalifikált szellemi dolgozók és a fizikai foglalkozásúak, illetve az alsó és a felső státuszúak) között a legmagasabb a disszimilaritási index és az egymással szomszédos csoportoknál (pl. szakmunkások és 
gazdálkodók, szakképzetlenek illetve az alsóközép és alsó státuszúak) a legalacsonyabb a mutató. A szélső kategóriák között átlag körüli a disszimilaritási index értéke, vagyis a nagyobb társadalmi távolság nagyobb térbeli elkülönüléssel jár, és fordítva: a kisebb társadalmi távolság kisebb disszimilaritással. A szegregációs index a felső kategóriáknál a legmagasabb, majd csökkenni kezd egészen a középső kategóriákig, ahonnét ismét emelkedik, de a legalsó helyzetű csoportnál már nem éri el a mutató a legfelső értéket, azaz a szegregációs görbe J-re emlékeztet ${ }^{1}$.

A szegregációs és a disszimilaritási indexek kiszámításakor a funkcionális övezeteknél rendre alacsonyabbak az értékek, kiváltképp a kisebb területen koncentrálódó alacsony társadalmi státuszúaknál. E megfigyelés elméleti magyarázatát adja Ladányi János (2008), aki szerint a klasszikus városszociológiai modellek korlátja, hogy a nagy területi aggregátumok alapján felépített modellek szükségképp heterogén területeket foglalnak magukba, elfedve ezzel a kisebb léptékü szegregálódást.

A mentális térképes adatok elemzését illetően Ferencz tanulmányából az derül ki, hogy a szegediek mentális térképe jelentősen eltér a statisztikai módszerekkel vázolt társadalmi-térbeli szerkezettől. Meglehetősen megoszlanak a vélemények a szegények által lakott városrészekröl, ellenben a gazdagok lakhelyeire vonatkozó vélemények inkább „konszenzusosak”, koncentráltak. Közös bennük, hogy a megkérdezettek által említett területek a központi vagy ahhoz közeli fekvésűek, míg a többi városrész mintha „látószögön kívül” esne.

A szegedi mentális térképek elemzésének első eredményei megerősítik azokat a budapesti kutatási eredményeket, miszerint a magas társadalmi státusúak jellegzetessége a nagy kiterjedésű, egybefüggő területen való szegregálódás, míg a társadalmi rétegződés alsóbb régióiban a sok kisebb méretű szegregátum jellemző (Ladányi, 2005). A jelenségre adható „empirikus” válasz: a megkérdezettek jól lokalizálható területeken észlelik a szegénységet, azonban azt sem zárható ki, hogy az általuk említett

\footnotetext{
${ }^{1}$ Csanádi Gábor és Ladányi János Budapesten végzett kutatásai szerint is a szegregációs görbe Jalakot vesz fel - a többi európai nagyvároshoz hasonlóan -, mert a társadalmi hierarchia alján elhelyezkedők térbeli elkülönülést jelző indexei alacsonyabbak, mint a hierarchia tetején lévőknél, szemben az Egyesült Államok nagyvárosaival, ahol a görbe U-alakot követ. Ennek oka, hogy a magas státusúak akaratuk szerint koncentrálódhatnak, míg a szegények mikro-szegregátumokban élnek (Ladányi 2007). Az európai nagyvárosok másik sajátossága, hogy a belső területeket a felsőbb társadalmi rétegek veszik birtokukba és sajátítják ki, kiszorítva onnan az alacsonyabb rétegeket (Castells 2005).
} 
városrészekben huzamosabb ideig alacsony, illetve magas társadalmi státuszú emberek laktak/laknak és ez az információ sztereotípiák formájában rögzült a válaszadók mentális struktúrájában. A preferált területek és a gazdagok lakta területnek gondolt városrészek a mentális térképen fedik egymást.

Boros Lajos a kutatássorozatban összevont mutatók segítségével kíséreli meg mérhetővé tenni a deprivációt (Boros 2011). Az általa alkalmazott halmozott és összevont deprivációs indexek városon belüli különbségei jól mutatják az objektív illetve szubjektív (relatív) depriváció térbeliségét, és a kétféle depriváció területi szerkezete közötti hasonlóságokat és különbségeket. Boros először a 2001. évi népszámlálás Szegedre vonatkozó adatait használja fel az objektív depriváció mutatóinak készítésére, majd ugyanezt elvégezi a Szeged Studies 2007 adatfelvétel 2500 fös lakossági mintáján is. Az elemzések területi alapegységét a népszámlásban elkülönített városrészek jelentik. A népszámlálási adatok alapján az objektív deprivációt vizsgálja, azaz olyan mutatók felöl közelít, amely az életminőség vizsgálatában a mérhető, könnyen számszerüsíthető és az egyén véleményétől független tényezőket reprezentálják. Az adatok feldolgozása során a gazdasági aktivitás, iskolázottság, lakáshelyzet, demográfiai helyzet mutatócsoportokat vonja be az elemzésbe. Boros összeveteti a relatív depriváció értékeit a népszámlálási adatok alapján számított objektív deprivációval és eredményként azt kapja, hogy a belvárosi területek jobb értékeket mutatnak a relatív depriváció tekintetében, míg az egyébként jó helyzetet mutató újszegedi területek hasonlóképpen differenciálódnak mindkét típusú depriváció alapján.

A kertes házas illetve ritkább beépítésü részek (Marostő, villanegyed) jobb értékeket mutatnak, mint a panelesek (Odessza), ugyanakkor ez utóbbira is városi átlag feletti az érték.

Kiskundorozsma és Tarján minden módszer és szempont szerint a város legdepriváltabb részei közé tartoznak. Szintén hátrányos helyzetünek bizonyul az Északi városrész.

Az objektív mutatók alapján rossz helyzetü Móraváros ugyanakkor a relatív depriváció alapján átlagos helyzetünek bizonyul. Alsóváros a relatív deprivációs index alapján jó helyzetủ városrészként jelenik meg, amelyet alátámasztanak a népszámlálási eredmények is: csupán az inaktív keresők aránya magasabb a városrészek átlagánál. 
Boros arra a következtetésre jut, hogy a legkedvezőbb helyzetben a piaci viszonyok által felértékelt központi, jól megközelíthető illetve a ritkább beépítésü, kellemes lakókörnyezetet nyújtó városrészek vannak. Ez utóbbiak elérhetősége szintén viszonylag jó - legalábbis a többi lazább beépítésű területhez (pl. Gyálarét, Kiskundorozsma) hasonlítva. Minden esetben kimutatható a paneles negyedek relatív lemaradása a szomszédos területekhez képest, és több esetben a város egészéhez képest is. A város szerkezetét formáló globális hatások különböző formában jelennek meg, és befolyásolják a depriváltság mértékét: a felértékelődő újszegedi területeket ezek teljesen elkerülik, hozzájárulva azok értéknövekedéséhez azzal, hogy a nyugodt lakókörnyezetet nem zavarják meg az új hatások. Ez igaz pl. Odessza városrészre is, amely némiképp jobb helyzetben van, mint a többi paneles lakóövezet. (Boros 2011)

\section{A KUTATÁS FOGALMI ÉS MÓDSZERTANI KERETEI}

\section{VII.1. A társadalmi pozíció meghatározása}

Peter Blau szerint a társadalmi rétegződést meghatározó strukturális paraméterek alkotják azon társadalmi pozíciók többdimenziós tengelyeit, amelyek alapján meghatározható maga a társadalmi struktúra (Blau 1976). Ezek a paraméterek jelentik az ember olyan attribútumait, amelyek befolyásolják szerepviszonyaikat, ezáltal megkülönböztetik társadalmi pozíciójukat. Akár az egyén vele született attribútumáról, mint pl. a nem, akár szerzett attribútumról van szó, mint mondjuk az iskolai végzettség, észrevehető hatást gyakorol a társadalmi pozíciókra. A strukturális paramétereknek két alaptípusa van: nominális és graduális (Blau 1976, Angelusz 1999:359-382).

A társadalmi rétegződés és struktúra kutatói, illetve a városszociológusok kiemelten kezelik a lakóhely szerepét a különböző egyenlőtlenségek kialakulásában (Konrád-Szelényi 1971, Kolosi 1987, Csanádi-Ladányi 1992). Mint minden nominális paraméter, így a lakóhely is jól körülhatárolható alcsoportokra bontja a populációt, emellett kapcsolatba hozható a hierarchikus státusbeli különbségekkel is (Blau 1976, 2004). Ha lakóhely alatt a városon belüli elhelyezkedést értjük, akkor ebből kiindulva azt mondhatjuk, hogy összekapcsolódva a graduális paraméterekkel a lakókörnyék is 
hozzájárul a társadalmi egyenlőtlenségek rendszeréhez, a szerepviszonyok és a társadalmi státuszok rendszeréhez. Nemcsak azt jelenthetjük ki, hogy bizonyos paramétereket tekintve Szeged népessége nem egyenletesen oszlik el a térben, hanem azt is, hogy a létrejövő egyenlőtlenségek térbeli mintázottsággal is bírnak.

A városszociológiában leggyakrabban használt, társadalmi helyzet szerinti területi elkülönülést meghatározó paraméterek összességének meghatározására véleményünk szerint a Peter Blau által felvázolt tipológia teljes mértékben alkalmazható. Ezért kutatásunk kvantitatív szakaszában, az operacionalizálás során, valamint az elemzéskor is az egyes elemzési egységek társadalmi hovatartozásának meghatározására ezen tipológiában szerepeltetett strukturális paramétereket vettük alapul.

\section{Nominális paraméterek}

A nominális paraméter éles vonalú alcsoportokra osztja a populációt. Ezen csoportok között nincsen belülről fakadó rangsor, bár tapasztalatilag a csoporttagságot összefüggésbe lehet hozni a hierarchikus státusbeli különbségekkel.

\section{Graduális paraméterek}

A graduális (lépcsős) paraméter a státus-rangsor alapján különbözteti meg az embereket. Itt a státusátmenet elméletileg folyamatos, ami azt jelenti, hogy maga a paraméter nem húz határvonalat a rétegek között. Az empirikus eloszlás azonban rámutat olyan szakadásokra, amelyek osztályhatárokat jelölnek.

E két társadalmi rétegződést meghatározó paramétertípus szerint két társadalmi pozíció különböztethető meg: a csoporttagság és a státusz (Angelusz 1999:359-382).

A társadalmi rétegződés és térbeli elkülönülés összefüggéseit vizsgáló kutatások egyik fő módszertani problémája - amelyre a későbbiek során részletesen is kitértünk egyrészt a vizsgált területi egységek kiterjedése, másrészt, ami ezzel a problémával szorosan összefügg, a vizsgálati minta nagysága. A legpontosabb adatokat ilyen jellegü vizsgálatoknál csak akkor kaphatnánk, ha a teljes alapsokaság társadalmi rétegződést meghatározó paramétereit ismernénk, erre azonban legtöbb esetben nincs lehetőségünk. A teljes alapsokaság egyes paramétereit feltérképező ilyen lehetőség Szeged városára vonatkozóan a 10 évente ismétlődő népszámlálás. Azonban ezen teljes alapsokaságot érintő adatfelvételben sem kérdeznek rá minden egyes, Blau által meghatározott 
nominális és graduális paraméterre, csak néhányra, mint a nem, kor, iskolai végzettség, lakóhely, foglakozás, családi állapot, munkahely, nemzetiség és vallás.

A hazai városszociológiai kutatások eredményei azt mutatják, hogy a társadalmi rétegenként történő térbeli elkülönülés esetében - a Blau által meghatározott teljes paraméterlistán belül - jól meghatározhatóak azok a paraméterek, amelyek mentén a területi szegregáció leginkább megragadható (Ladányi 2008). Ladányi János Budapesten végzett vizsgálatai alapján a kor, iskolai végzettség, munkahely, és foglalkozás paramétereket sorolja azok közé, amelyek mentén leginkább kimutatható a társadalmi rétegenként történő térbeli elkülönülés.

Elemzésünket ezért mi is ezen a paraméterek alapján végezzük, hogy eredményeinket össze tudjuk hasonlítani a Ladányi által korábban Budapesten végzett hasonló jellegü kutatás eredményeivel (Ladányi 2008).

VII.2. A tér lehetséges értelmezési keretei

A mentális térképezés módszerét alkalmazó különböző tudományterületek térértelmezéssel kapcsolatos prioritásai különbözőek. A földrajztudományban például a legfontosabb kategóriák a hely és a tér, melynek változásait az idő hordozza.

A társadalomtudományokban pedig a térnek az a fajta értelmezése az elsődleges, amelyet a személyek (a társadalom eltérő csoportjaiba tartozó egyének) a reális konkrét (objektív) térből sajátosan érzékelnek, értelmeznek.

Mészáros Rezső (2000) a tér két főcsoportját, ezen belül pedig öt különböző fajtáját különbözteti meg:

1. Objektíven meghatározható elméleti terek

2. A matematikai és geometriai terek

Azok a terek, amelyeket a geográfia a környezet, a tér leíráshoz leginkább felhasznál, amelyek megjelennek a földrajzi térképeken illetve a földrajzi folyamatokat leíró modelleknél is. Ez a tér, melyben a földrajzi távolságok valósak, és a „hagyományos jellegü” térképeken ezek a távolságok arányosan jelennek meg. Akár egy települési térképen, melyben a település utcái, terei stb. méretarányosan láthatók, vagy akár egy kistérség térképén, melyen a települések (város(ok), favak, majorok, tanyák stb.), a közutak, a vasút, és az egyéb térelemek mind-mind a valós földrajzi távolságuk 
és kiterjedésüknek megfelelően, méretarányosan, az euklideszi geometria szabályai szerint leképezve jelennek meg.

\section{A fizikai terek}

Olyan terek, melyekben egy adott, vizsgált jelenséghez (pl. települések közötti utazási időhöz) arányosítják a földrajzi távolságokat. A települések közötti távolságokat a földrajzi távolságok helyett meghatározhatjuk a köztük fennálló utazási időkkel is, vagy esetleg az utazási költségekkel. Az így kapott térkép ugyan különbözik a jól megszokottól, ugyanakkor jobban kifejezi - ebben az esetben - egy adott település (időbeli vagy költségbeli) elérhetőségét.

4. A társadalmi és gazdasági terek

Ebben a fajta térértelmezési megközelítésben a gazdasági és társadalmi kapcsolatok és folyamatok a meghatározóak. A gazdasági-társadalmi terek fö tulajdonságai a gazdasági és társadalmi jellegű paraméterek által meghatározott jellegzetességek.

A tereket egyedi helyek építik fel, mely helyek különböző tulajdonságokkal bírnak, és az adott hely értéke a többi helyhez viszonyítva adódik akár társadalmi, akár a gazdasági folyamatok értelmezési keretében. (Mészáros 2000)

\section{A viselkedési terek}

Olyan terek, amelyeket az emberek a mindennapi életük során tapasztalnak, és amiben mindennapos döntéseiket hozzák. Nem azonosak azokkal az objektíven meghatározható elméleti terekkel, amelyek a matematikai, fizikai és társadalmigazdasági terek csoportjába tartoznak. (Mészáros 2000) Minden ember más, éppen ezért az a tér, ami az adott emberben kialakul a valóságos tér leképeződéseként, az is más és más. Ugyanakkor fellelhetők hasonlóságok a különböző emberek által érzékelt, értelmezett tereket tekintve. Hiszen az azonos társadalmi csoportba tartozók számára általánosságban ugyanazon jelenségek, térelemek fontosak, illetve a környezetnek ugyancsak hasonló térelemei és jelenségei jelentéktelenek. 


\section{VII.3. A mentális térkép}

A mentális térképek vizsgálata egyes kutatók szerint már a századforduló néprajzi és antropológiai irodalmában is megjelenik térhasználat címke alatt. (Letenyei 2004) Az antropológusok körében sokat idézett Bronislaw Malinowski a Trobriand-szigetek közötti kereskedelmi lánc leírásakor utal arra, hogy a szigetek lakói a közvetlenül szomszédos szigeteket tartják közelinek, és ez az elképzelés hatással van a kereskedelmi kapcsolatok alakulására (Malinowski 1922). A térhasználattal kapcsolatos hazai néprajzi irodalomból nemzetközileg is ismert Hofer Tamás és Fél Edit (1997) munkája a magyar paraszti gazdálkodás tér- és időbeosztásáról (Letenyei 2004).

A térértelmezéssel kapcsolatos értelmezési valamint ezen értelmezési fajták különböző kutatási területeken használatos prioritásbeli különbségeinek eredményeképp jönnek létre az 1960-as, 1970-es években a mentális térkép, mentális térképezés vagy a kognitív tér, a kognitív térképezés fogalmai (Nemes Nagy 1998).

„A kognitív térképezés pszichológiai folyamatok sorozatából álló folyamat, amely megjegyzi, kódolja, raktározza, elöhívja és dekódolja a mindennapi térbeli környezetre (...) vonatkozó információt.” (Downs-Stea 1973 idézi Letenyei 2004) Tehát a kognitív térképezés azt a folyamatot jelöli, melynek során a személyekben lejátszódik egy pszichológiai folyamat, aminek az eredményeképpen kialakul egy sajátos kép, a valóságos térnek egy sajátos értelmezéseként. Ez a sajátos kép, a kognitív térkép, melyek, „térképi elemekből, illetve a hozzájuk kapcsolódó szubjektív képzetekből álló tudati képződmények", a mentális térképezés lényege pedig, éppen ezeknek, az egyénekben rejlő kognitív térképeknek feltárása, különböző módszerekkel. Így a mentális térkép csupán az egyén kognitív térképének adott eszközökkel megjelenített része. (Kiss 2005) A kognitív térkép tehát nem mentális térkép még, hanem mentális kép, amely különböző módszerekkel megjeleníthető, és ennek a megjelenítésnek (mentális térképezés) eredménye a mentális térkép.

A társadalomtudományok számára a térbeliség nem tisztán jelenik meg, hanem átszövi számtalan társadalmi és kulturális jelentés. Ezzel a teret társadalmi termékké avatja, és annak mentális jellegét hangsúlyozza. E jelentések hordozói, megjelenítői, sőt 
formálói a társadalmi élet legkülönfélébb területei, megnyilvánulásai, így például a müvészeti alkotások, vagy általánosságban az információcsere, a kommunikáció. (Mészáros 2000, Benedek 2003, Farkas 2003)

Más diszciplínák a két kifejezést eltérő jelentésben használják, illetve több, ezekhez hasonló hangalakú és/vagy rokon értelmü kifejezéssel találkozhatunk, mint pl. értéktérkép, koncepciótérkép, szemantikus térkép, történelmi városrészek stb. (Letenyei 2004) Egyes vélemények szerint a kognitív vagy mentális térképezés (cognitive/mental mapping) két különböző dolgot jelent a pszichológia és társadalomföldrajz szóhasználatában. A két diszciplína megközelítésbeli különbözősége Letenyei László szerint leginkább úgy értelmezhető ,, mintha fordított lenne a kutatás tárgya: a földrajz a térre vonatkozó tudást gyüjti, a pszichológiai értelemben vett kognitív térkép viszont a tudást térképezi fel, azaz a tudati jelentésstruktúrák, „térképének” elkészitésével foglalkozik." (Letenyei 2004:154)

Más kutatók ellenben, mint pl. Barbara Tversky is úgy látják, hogy a kétfajta fogalomhasználat között nincs különbség, hiszen mindkét esetben a tudattartalmak feltárásáról, feltérképezéséről van szó, és a tudat vizsgálatakor képtelenség lenne a vizsgálatot csak és kizárólag a térrel kapcsolatos tartalmakra szükíteni, hiszen a kognitív folyamatok csak a maguk komplexitásában értelmezhetők. (Tversky 1993 - idézi: Letenyei 2004:154)

Összefoglalva tehát kijelenthetjük, hogy nem sok olyan tudományos érdeklődési terület született olyannyira interdiszciplináris környezetben, mint a mentális térképezés. A térre vonatkozó tudattartalmak vizsgálatai a különböző tudományterületeken (a földrajz, a pszichológia, a nyelvészet és a társadalomtudományok, elsősorban a kulturális antropológia területén) az 1960-as évektől kezdve egy időben jelentek meg, és kölcsönösen hatást gyakoroltak egymásra. (Letenyei 2004:157)

\section{A MENTÁLIS TÉRKÉPEZÉS ELMÉLETI ÉS MÓDSZERTANI HÁTTERE}

A kulturális antropológiában az ötvenes-hatvanas években végbemenő strukturalista és kognitív fordulat már a térérzékelés vizsgálatának felértékelődéséhez vezetett (Letenyei, 2004). Ugyanakkor a geográfiában csak az 1960-as évek behaviorista 
forradalmával $^{2}$ jelent meg a módszer, amit ma már széles körben használnak a települési, területi tervezésben is, mivel segítségével olyan társadalmi folyamatokról kapható információ, amelyek más módszerekkel nem, vagy csak korlátozott mértékben tárhatók fel. (Kiss-Bajmócy 1996)

Letenyei szerint a geográfia és antropológia mellett a nyelvészetben is tetten érhető a mentális térképezéssel kapcsolatos kérdések megjelenése, mégpedig a környezetre vonatkozó, kulturálisan meghatározott tudás és a kommunikáció összefüggéseinek vizsgálata terén. Letenyei kiemeli, hogy a nyelvészet és az antropológia kognitív struktúrák iránti fokozódó érdeklődése sok tekintetben egymás mellett, szoros kölcsönhatásban haladt. Ennek egyik legismertebb bizonyítéka Edward T. Hall Rejtett dimenziók címü könyve.

A kötet a környezetre vonatkozó, kulturálisan meghatározott tudás és a kommunikáció, illetve a nyelv kérdéseivel foglalkozik, és számos fontos megállapítása mellett rámutat arra is, hogy az ember és környezete kölcsönösen alakítják egymást. Vagyis az ember miközben megteremti a kultúrát, aközben „háziasítja” is magát; és a kultúra nyelvén keresztül ismeri meg a valóságot. Így az építetett (városi) környezet sem más, mint a kultúra szürő-szelektáló folyamatának terméke. Hall szerint tehát a térre vonatkozó elképzeléseink elsősorban nem az objektív valóságon, hanem annak szubjektív észlelésén nyugszanak (Hall 1969, 1987).

Láthatjuk, hogy a mentális térképezés területén a legkülönbözőbb tudományágak, mint a nyelvészet, a pszichológia és a földrajz kutatási eredményei kölcsönösen hatottak egymásra. A módszer interdiszciplináris jellegét támasztja alá az is, hogy az egyébként építész végzettségű Kevin Lynch munkája (Lynch 1960) készítette elő - Cséfalvay Zoltán értékelése szerint - a földrajztudomány egy újabb fordulatát (Cséfalvay 1990). 1970-ben megjelenik a földrajzkutató Roger Downs Geographic Space Perception: Past Approaches and Future Prospects címü programadó írása (Downs 1970), majd 1973ban a David Stea-vel közösen szerkesztett szöveggyüjtemény (Downs-Stea 1973a, 1973b), amely viszont a pszichológus végzettségü, de számos diszciplína területén

${ }^{2} \mathrm{Az}$ Egyesült Államokban megjelent iskola képviselői a hatvanas években szakítottak a hagyományos földrajzi szemlélettel, amely a teret az emberek cselekedeteinek kereteként szolgáló „tartályként”, abszolút képződményként tekintette. Abból a feltevésből indultak ki, hogy az emberek térbeli viselkedését nem a tér objektív szerkezete, hanem annak az észlelés során keletkezett szubjektív képzete határozza meg. (Cséfalvay 1990) 
alkotó Stanley Milgram-re volt hatással, aki 1976-ban tette közzé Párizs mentális térképéről szóló tanulmányát (Milgram 1992).

Ezután még gyors egymásutánban több összefoglaló jellegü kézikönyv. Egyetemi jegyzet is megjelenik, mint például Peter Gould és Rodney White Mental Maps címü (Gould-White 1974), a Downs és Stea szerzőpáros újabb, Map in Minds. Reflection on Cognitive Mapping címú írása (Downs-Stea 1977), továbbá Joseph Stoltman 1980-as Mental maps: resources for teaching and learning címü kötete (Stoltman 1980) és John Goldnak a behaviorista geográfiai megközelítésben íródott An Introduction to Behavioural Geography címü írása (Gold, 1980). Végül Charles Holahan környezeti pszichológiai megközelítésű mentális térképezésről íródott kötete (Holahan 1982) amelynek hat fejezete magyarul is olvasható (Dúll-Kovács 1988) - zárja a mintegy 20 éves kezdeti periódust.

1993-ban Barbara Tversky a kognitív térképeken kívül konstruktivista alapokon álló kognitív kollázsokat és térbeli mentális modelleket különít el. Az így létrejött hármas kategorizáció lényege, hogy míg a kognitív térképezés a térre vonatkozó tudati tartalmakat gyüjti, a kognitív kollázs (cognitive collage) a térészlelésünk sokkal több tudati elemével függ össze. Egy távolság megítélésénél például figyelembe vehetjük a kocsiút idejét, a zónaidőt, de akár a történelmi hadjáratokat vagy a nyelvcsaládot, és ezekből kollázsszerüen állítjuk össze a térre vonatkozó információt (Tversky 1993). „A megközelités attól konstruktivista, hogy az érdeklödés középpontjában nem a térkép (kollázs) áll, hanem alkotásának folyamata. A dolgot bonyolítja, hogy az információk szisztematikus vagy véletlen hibával állnak rendelkezésünkre tudatunkban. A térbeli mentális modellek (spetial mental models) abból indulnak ki, hogy az egyes térbeli információk nem állnak össze egy teljes képpé, a biztos pontok (landmarks) közti teret a tudatunk tölti ki, modellezi."(Letenyei 2004:162). A mentális térképezés konstruktivista jellegü megközelítése tehát nem a térképre, hanem magára a modellépítés folyamatára fókuszál.

A mentális térképezés elméleti és módszertani alapjaira építő megközelítések közül megemlítendő még a szociálpszichológiában használatos value mapping, amely az értékpreferenciák (szociológiai, pszichológiai) vázlatát, illetve az eredmények sokdimenziós skálázás eredményeként kapott „térképét” jelenti. Az 
ingatlanpiaci/területfejlesztési értelemben vett értéktérkép pedig egy teljesen más, kognitív stuktúraértelmezés, ahol egy-egy település ingatlanpiaca színárnyalatokkal vagy más módon ábrázoló térképre, vagy a térkép alapjául szolgáló adatbázisra, azaz értékkataszterre utal. A szervezetszociológia, vezetés- és szervezéstudományok területén az úgynevezett koncepciótérképezés (concept mapping) kifejezést említhetjük, ahol gyakorlatilag egy elképzelés megvalósításának komplex folyamatábrája megalkotásáról beszélhetünk, feltüntetve az egyes fázisokat, a részt vevő szereplöket és a társadalmi/szervezeti környezetet, az eredményeket grafikusan interpretálva. A koncepciótérkép egy vagy több résztvevő észlelése alapján készül (jellemzően fókuszcsoportos vizsgálat, ritkábban interjú vagy résztvevő megfigyelés alapján), az eredményeket általában adatsürítő eljárásokkal (MDS, klaszter) dolgozzák fel (Letenyei 2004).

A térrel kapcsolatos ismeretek előhívására alapvetően két módszert szoktak alkalmazni: az un. „rajzos” illetve „rang módszert”. Az első módszer alkalmazói a vizsgálati személyekkel térképeket rajzoltatnak, majd ezeket elemzik, hasonlítják össze. A második módszer előre megadott objektumok értékelésén alapul. Ekkor a kutató által megnevezett helyeket kell rangsorolnia, pontoznia a válaszadónak. Ebben az esetben a térképezést már maga a kutató végzi el. (Kiss-Bajmócy 1996)

Más megközelítésben a mentális térképezéshez kapcsolódó az adatfelvétel „filozófiáját” illetően lehet:

- $\quad$ Tisztán kvantitatív jellegü

- $\quad$ Tisztán kvalitatív, nem rajzoltató adatgyüjtés

- $\quad$ Szabad térképrajzoláson alapuló adatfelvétel

- $\quad$ Standarditásra törekvő térképrajzoltatás

- Kész térképekből kiinduló adatfelvétel

A mentális térképeken található adatok lehetnek:

- Mentális terek neve és kiterjedése (településrészek, utcanevek stb. megnevezése és ábrázolt nagysága, méretaránya) 
- Törésvonalak, határok (városhatár, folyó, jól meghatározható városmorfológiai határvonal stb.)

- Tájékozódási pontok (népszerü találkozási, vagy iránypontok, amelyek a mindennapokban segítik a tájékozódást)

- Útvonalak (nem csak konkrét utak lehetnek, hanem bővebb értelemben a mindennapi térpályák)

- $\quad$ Csomópontok (a térpályák találkozási pontjai; jelentőségüket többnyire az határozza meg, hogy hány útvonal, térpálya találkozik)

Emellett gyüjthetők adatok az egyes helyek, térrészletek ismertségről, a hozzájuk kapcsolódó véleményekről, sztereotípiákról. (Letenyei 2004)

\section{VIII.1. A könnyen tanulható város fogalma}

Lynch (1960) az „olvasható város” fogalma alatt azt érti, hogy a város egyes részei milyen könnyen ismerhetők fel és rendezhetők egy koherens rendszerbe. Hasonlóan ehhez a nyomtatott oldalhoz, ha ez elolvasható, akkor vizuálisan felfogható mint ismert szimbólumok egymással összefüggő rendszere. Így az a város tekinthető olvashatónak, melynek kerületei vagy müemlékei vagy közlekedési útvonalai könnyen felismerhetőek és egy globális szerkezeti sémába rendezhetőek.

Ehhez szükséges a városképi elemek megkülönböztethetősége, illetve azok logikus, követhető összekapcsolódása. A világosan tagolt szerkezetű városokról könnyen és gyorsan készíthetünk viszonylag pontos kognitív térképet. Lynch (1960) három fázist különít el a térbeli tanulás folyamatában: az azonosítás, a struktúrateremtés és a jelentésadás egymással összekapcsolódó szakaszait. Az azonosítás legnyilvánvalóbb formája az elnevezés, aminek során az adott térelemet megkülönböztetjük környezetétől.

A struktúrateremtés során az egyes helyek, térrészletek egymáshoz való viszonyát, funkcionális kapcsolatát adjuk meg. Végezetül a jelentésadás szakaszában, amely a három közül a legnagyobb változatosságot hordozza, különféle jelentéstartalmakkal ruházzuk fel az egyes helyeket. E jelentések akár teljesen ellentétesek is lehetnek másmás csoportokhoz tartozóknál, erre kiváló példa az, hogy mennyire tér vagy térhet el 
például a belvároshoz kapcsolódó jelentéstartalom egy település lakosságának és az odalátogató turistáknak esetében (Cséfalvay 1990).

Az értekezés egyik kulcsfogalma a könnyen tanulható, „olvasható” város. Amely alatt Lynch (1960) nyomán azt értjük, hogy az épített környezet sajátosságai lehetővé teszik, hogy a várost könnyen értelmezzük és újjáteremtsük tudatunkban Lynch (1960).

Lynch (1960) definíciójában szereplő paramétereket, amelyek az épített környezet sajátosságaira vonatkoznak, kutatásunk során kibővítjük a társadalmi mintázat valós és kognitív sajátosságainak paramétereivel. Ezalatt azt értjük, hogy a város nem csak és kizárólag az épített környezet alapján tanulható könnyen, hanem a társadalmi-térbeli elkülönülés mintázatán keresztül is.

Az feltételezzük, hogy azokban a városokban készül a társadalmi-térbeli elkülönülésről viszonylag pontos kognitív térkép, ahol a társadalmi térbeli elkülönülés nagyobb területi egységet lefedő, nagyobb homogenitással jellemezhető.

\section{VIII.2. A sztereotípia fogalmának meghatározása}

A sztereotípia lényege a kategorizáció. A sztereotípia a kategóriával társult túlzó nézetként jellemezhető, ahol a kategória alatt olyan nyelvileg megjelölt osztályt értünk, amelybe a köznapi gondolkodás besorolja az embereket, dolgokat, eseményeket. Ennek a fogalomfelfogásnak a továbbfejlesztését és kiterjesztését hozta az a máig meghatározó látásmód, amely az információ-feldolgozási paradigmával fémjelezhető. Az embernek az evolúció során a túlélés érdekében meg kellett felelnie a gyors döntéshozatal és hatékony információkezelés követelményének, azonban a környezetből érkező információmennyiség hatalmas áradatával csak úgy tud megbirkózni, ha az információkat csoportosítja, ill. kategorizálja közös elemeik vagy sajátosságaik alapján. (Hunyady 1996)

A kategorizációnak 3 fő funkcióját határozhatjuk meg:

1. a környezet leegyszerüsítése,

2. elvárások alkotása,

3. nagyobb információmennyiség hatékony feldolgozása 
Ez a felfogás már nem választja el a kategóriát és a sztereotípiát, hanem azt állítja, hogy a sztereotípia maga is olyan racionális kategória, amely a világ szervezésének egyszerü kognitív struktúrája, egyfajta intuitív absztrakciós modell, mentális reprezentáció. A kategóriáknak azonban egy speciális válfaját alkotják, amennyiben a legtöbb kutató egyetért abban, hogy ,,[...] a sztereotípiák társadalmi csoportoknak vagy rétegeknek tulajdonitott jellemzöket foglalnak magukba”. (Hunyady, 2001:53), melyek társadalmilag elfogadott hiedelemrendszereket alkotnak; a sztereotípia maga pedig szociális kategóriák mentális reprezentációja." (Hunyady, 2001:146)

A sztereotípia kialakulásának alapja az emberek személyes szükséglete arra, hogy feltérképezzék, mentálisan strukturálják környezetüket. (Hunyady 2001)

\section{VIII.3. A szegregátum fogalma}

A KSH a 2001-ben végzett népszámlálási adatok alapján azokat a területeket nevezi szegregátumoknak, ahol az aktív korú népességen belül, a legfeljebb általános iskolai végzettséggel rendelkezők, és a rendszeres munkajövedelemmel nem rendelkezők aránya mindkét mutató esetében magasabb, mint 50\%. Azokon a területeken, ahol a lakosok számának legalább 40\%-a a fent említett mutatók szerint alacsony státuszú, veszélyeztetett területnek minősülnek.

Értekezésünk során a kvantitatív adatok másodelemzésekor ebből adódóan mi is fentebb leírt szegregátum definíciót tekintjük alapnak.

A Városrehabilitáció 2007-2013-ban. Kézikönyv a városok számára című kiadvány (A kiadvány szerzőket név szerint nem nevez meg, csak az alábbi gazdasági társaságokat: Vitalpro Kft., Városkutatás Kft., Városfejlesztés Zrt, mint közremüködő szakértőket) is a KSH által meghatározott mutatók szerinti szegregátum-definíciót használja.

Ennek alapján városszerkezetileg a szegregátumoknak alapvetően két típusát határozza meg: 
1. a városszövetbe ágyazódott szegregált, szegregálódó területek (általában ezek jelentik a telepszerü környezetet)

2. a városszövettől elkülönült, alapvetően nem lakófunkciójú területekbe ékelődött szegregátumok (általában ezek jelentik a telepeket). (VRK 2007:118)

Elsősorban városrész szintü társadalmi (demográfiai, szociális helyzet) adatok amelyek a Központi Statisztikai Hivatal 2001-es népszámlálási adataiból lekérhetőek képezhetik az alacsony státuszú népességet koncentráló területek beazonosítását. A szegregált terület definíciója szerint a két mutatónak együttesen megfelelő lakosok magas koncentrációja határozza meg a szegregátum létét.

A dokumentum a szegregátumok lehatárolását a népszámlálási adatokon kívül még önkormányzati adatokkal kiegészítve határozza meg:

1. a segélyezési adatok megoszlásának vizsgálata: az önkormányzati segélyek városrészek közötti megoszlásának, illetve a városrészeken belül egy adott területre való koncentrálódásának vizsgálata

2. önkormányzati bérlakások magasabb koncentrációja egy adott területen

3. alacsony infrastrukturális ellátottsággal (közmüvek, pormentes út, járda hiánya) rendelkező területek vizsgálata

4. külterületen, nem lakóövezetben elhelyezkedő lakott területek vizsgálata telepszerü képződmények helyzetének elemzése. (VRK, 2007:118)

A kézikönyvben leírtak alapján egy ún. anti-szegregációs terv is kötelező része minden integrált városfejlesztési stratégiának ${ }^{3}$, abban az esetben is, ha a város 2008-ban még nem tervezi, hogy a szociális célú városrehabilitációs konstrukcióra pályázik.

\footnotetext{
${ }^{3}$ Integrált Városfejlesztési Stratégia, amely dokumentáció megléte szükséges feltételét képezi a szociális célú városrehabilitációs konstrukcióra pályázó települések számára. Az integrált városfejlesztési stratégia városrészekre vonatkozó elemzése kimutatja, hogy melyek a város rosszabb státuszú területei, ahol a népesség társadalmi összetétele és a terület fizikai jellemzői is kedvezőtlenebbek. Célja, hogy a rosszabb státuszú területeken belül meghatározza azokat a kisebb területegységeket, ahol a szegregáció már elörehaladott, illetve azokat, melyeket a szegregáció elmélyülése veszélyeztet. Az általános tapasztalatok alapján elmondható, hogy ezeken a területeken az alacsony státuszú roma népesség koncentrációja igen magas, éppen ezért a városi szegregátumok meghatározásának egyik elsődleges célja az ilyen jellegü területek lehatárolása. A város-rehabilitációs pályázatokhoz eddig 160 anti-szegregációs terv készült, amelyekben a városoknak be kell mutatniuk, hogy a 2013-ig terjedő időszakban milyen beavatkozásokat, intézkedéseket tesznek annak érdekében, hogy a cigánytelepeken élők lakhatási, szociális, egészségügyi, foglalkoztatási integrációja megvalósuljon. (Forrás, 2009.11.12. http://www.magyarorszag.hu/hirkozpont/hirek)
} 
Az integrált városfejlesztési stratégia keretén belül kidolgozandó anti-szegregációs terv, kimondottan csak a szegénységi szegregátumok feltérképezésével foglalkozik, tehát csak egy, de igen fontos részét képezi a települési esélyegyenlőségi program kidolgozásának.

Az anti-szegregációs terv elsősorban területi dimenzióban, a szegregációs folyamatok szempontjából vizsgálja az esélyegyenlőségi problémák meglétét egy adott településen. Az Anti-szegregációs terv célja, hogy a város felmérje azon területeit, ahol a szegregáció már megindult, illetve ahol elörehaladott állapotban van, és a fentiek szellemében kidolgozzon a szegregáció oldására irányuló programokat.

\section{A MENTÁLIS TÉRKÉPEZÉS HAZAI KUTATÁSI ELŐZMÉNYEI}

Magyarországon is egyre több kutató mutat érdeklődést a mentális térképezés iránt, és végez kutatásokat. Ezek két fő csoportra oszthatók: egy-egy település mentális képére, vagy összességében - többnyire a magyarországi települések kapcsán Magyarország mentális képére irányulnak (Letenyei 2005).

Letenyei Köszeg, Ököritófülpös mentális képét vizsgálta, utóbbi településnél kiegészítve kapcsolatháló elemzéssel (Letenyei 2001). Perényi Roland Budapest sajátos szempontú vizsgálatát végezte el, mégpedig abban az értelemben, hogy a rendőri figyelem, a biztonság (biztonságérzet) terjedését elemezte a dualizmus korának fővárosi társadalmában dokumentumelemzés módszerét használva (Perényi 2006).

Gyáni a városi mikroterek kutatása során arra a megállapításra jut, hogy a város térképe sok eltérő mentális térképet rejt magában. Kutatásaiban történeti forrásokat (korabeli családi naplókat) használt, és kiindulópontja az volt, hogy a várost annak lakói eltérően észlelik, így vele kapcsolatos élményeik is eltérőek. Gyáni végül arra a következtetésre jut, hogy a várost mint egységet szimbolizáló tárgyi elemekről nyert élmények nélkül nem lehetséges a városi identitás érvényes kialakítása (Gyáni 1998).

Garamhegyi, Kádár és Sümeghy alföldi lakóhelyü egyetemisták Magyarországról alkotott mentális térképét vizsgálták. Kiindulópontként egy üres lapot kaptak a megkérdezettek, amelynek a közepén egy pont jelölte Szegedet, és a városhoz képest 
kellett megadniuk az egyes településeket. A szakirodalomban ezt „céltáblás” módszernek nevezik (Letenyei 2004).

Bajmócy és Kiss (1996) szintén az egyetemi hallgatók mentális térképeit vizsgálták Magyarországról, összehasonlítva az (elvileg) több földrajzi információval rendelkező földrajzosok és más szakosok térképeit. Más vizsgálatok az egyes európai országok népszerűségét, megítélését vizsgálták szintén egyetemi hallgatók körében rang módszer segítségével (Bajmócy-Csikos 1997).

Michalkó Gábor a turizmus kutatásában használta a mentális térképeket, amelyeket érettségi előtt álló diákokkal készíttetett el. Szerinte az adott helyen rövid ideig tartózkodó turisták mentális térképéhez jobban tapadnak a szubjektív értékítéletek, mint egy helyi lakoséhoz, emellett a látogatók térképeit elemezve képet kaphatunk a turisták útvonalairól, könnyebbé válik a helyi turizmustervezés. (Michalkó 1998)

A hazai mentális térképes módszert alkalmazó kutatások közül kiemelendő még Füstös László (Füstös 1988) és Varga-Ötvös Béla tanulmánya (Varga-Ötvös 1993). A két szerző más-más kontextusban végzett elemzése csak a címében egy. A Füstös által végzett értéktérkép elemzés és (value map) kifejezés a szociálpszichológiában az értékpreferenciák (szociológiai, pszichológiai) vázlatát, illetve az eredmények sokdimenziós skálázás eredményeként kapott „térképét” jelenti, míg Varga Ötvösnek az ingatlanpiaci/területfejlesztési értelemben vett értéktérkép értelmezése egy település ingatlanpiacát színárnyalatokkal vagy más módon ábrázoló térképet, vagy a térkép alapjául szolgáló adatbázist, azaz értékkatasztert jelenti.

\section{A VALÓS ÉS A MENTÁLIS TÁRSADALMI-TÉRBELI ELKÜLÖNÜLÉS ÖSSZEFÜGGÉSEINEK VIZSGÁLATA}

\section{X.1 Módszertan}

$\mathrm{Az}$ értekezés során Szeged város társadalmának 2001-2010 közötti területi mintázottságában bekövetkezett változásait kívánjuk áttekinteni objektív és mentális térképes adatok alapján, öt különböző kutatási módszer alkalmazásával:

1. Forráselemzés

2. Megfigyelés 
3. Mentális térképezés

4. Kérdőíves adatfelvétel

5. Másodelemzés

Az általunk alkalmazott kutatási módszerek a kvantitatív és kvalitatív módszerek ötvözésének elvén alapulnak, amely egyaránt biztosítja a magas megbízhatóságot és érvényességet.

Kutatási módszerünk egy kvalitatív-kvantitatív skálán mozog, amelynek két végpontját a terepközeli (kvalitatív) és tereptávoli (kvantitatív) módszerek képezik, a magasabb megbízhatóság és érvényesség érdekében (Letenyei: 2004:56-66).

Álláspontunk szerint csak és kizárólag az érvényes kutatási eredményeknek van értelme, ugyanakkor a megfelelő megbízhatóságra is törekedni kell. A két módszer ötvözésén alapuló adatfelvételnek a legfőbb előnye, hogy egyaránt magasabb érvényességű és megbízhatóságú adatokat tud biztosítani az elemzéshez, azáltal, hogy a kutatási kérdés megfogalmazása, annak relevanciája az adott terepen folytatott kvalitatív felvételek eredményeképpen megalapozottabbá válik, és így a kvantitatív kutatási szakaszra megfogalmazandó kérdések tekintetében magasabb érvényességet biztosít.

A survey típusú - helyes mintavétel esetén - nagy megbízhatóságú adatfelvételek érvényességi problémáinak egyik legfőbb oka a mérési hiba lehet, amely a nemmintavételi hibák csoportjába tartozik.

A nem-mintavételi hiba a hibáknak azon csoportja, amelyek az adatfelvételhez és az adatrögzítés jellemzőihez kapcsolódnak. Ide sorolunk minden olyan hibát, amely a mintavételen kívüli egyéb forrásokból ered (Marton 1994, Malhotra 2002). A nemmintavételi hiba nagysága - a mintavételi hibától eltérően - matematikai-statisztikai eszközökkel nem becsülhető, becslésekor kizárólag a szakirodalomban található empirikus adatokra, illetve saját tapasztalatainkra hagyatkozhatunk (HunyadiMundruczó-Vita 1997). A nem-mintavételi hibák akkor is fellépnek, ha a teljes populációt bevonjuk a felmérésbe.

A nem mintavételből származó hibáknak is több fajtáját különíti el a szociológiai szakirodalom (Telegdi 1999). A magas megbízhatóságú, azonban alacsony érvényességü eredmények okozója sok esetben a mérési hiba, ahol az érvényességi probléma abban ölt testet, hogy a mérőeszközünk, vagyis a kérdőívünk nem megfelelő. 
Ez jelentheti azt, hogy a kérdőívben feltett kérdéseknek rossz megfogalmazása vagy a félreérthetősége vagy az adott társadalmi közegben való érthetetlensége miatt a megkérdezett nem azt az adatot adja meg, amelyre a kutató kíváncsi (Telegdi 1999).

A mérési hiba okozta érvényességi problémával először a kérdezők szembesülnek a terepen, jobb esetben a próbakérdezés során, rosszabb esetben az éles adatfelvételkor. A hazai és nemzetközi kutatói gyakorlatban is a legtöbb esetben a standard strukturált kérdőíves adatfelvételi módszert alkalmazzák, amelynek legfőbb módszertani szabálya, hogy a kérdőív kérdéseit szó szerint mindenkinek ugyanúgy, ugyanabban a sorrendben kell felolvasni (Babbie 1996). Ezzel nem is volna probléma akkor, ha a kérdőívekben megfogalmazott kérdések minden esetben, az adott terepen mindenkinél ugyanazt jelentenék, de ez sok esetben nem így van, és mivel az ilyen standard strukturált kérdőíves adatfelvétel módszertani szabályai nem engednek semmilyen változtatást, a kérdezőbiztosnak akkor is úgy kell felolvasnia a kérdöív kérdését, ha a kérdezett abban a formában nem érti. Nem magyarázhatja el, nem cserélheti ki a szavakat, egyszóval nem tehet semmit, egyet kivéve: jelzi a kutatónak, hogy a kérdőív egyes kérdései, vagy netán az egész kérdőív, az adott terepen vagy társadalmi közegben nem müködik. Ha kérdezők jelzik is a mérési hibából eredő érvényességi problémát, a legtöbb kutató ilyenkor inkább a „homokba dugja a fejét” (Letenyei-Nagy 2007) mert már zajlik az adatfelvétel, benne egy csomó pénz és munka, és az összehasonlíthatóság véleményünk szerint - rugalmatlanul értelmezett módszertani szabályai szerint nem lehet a kérdések tartalmán kicsit sem változtatni.

A nem-mintavételi hibák okozta torzítás terepen történő csökkentésének egyik lehetséges módszere véleményünk szerint a több módszerrel végzett adatfelvétel, amely mérési hibából származó érvényességi problémák okozta torzulások csökkentésére alkalmas. A mérési hiba fó oka ugyanis az, hogy a kérdőív rossz megfogalmazása, félreérthetősége miatt a megkérdezett nem azt az adatot adja meg, amelyre a kutató kíváncsi (Telegdi 1999). A magasabb érvényességet az egyébként magas megbízhatóságú, de esetenként a nem megfelelően megfogalmazott kérdésekből adódóan alacsony érvényességü, survey vizsgálat esetében úgy biztosítottuk, hogy a mérőeszköz elkészítése előtt végzett terepmunka magas érvényességü adatai alapján alkottuk meg a kvantitatív mérőeszköz kérdéseit. 
Az adatgyüjtési módszerek ezen ötvözésén alapuló kutatáskor az ajánlott sorrend a különböző módszerek alkalmazásakor az, hogy a kvalitatív adatfelvételi módszerek felől haladjunk a kvantitatív eljárások irányába. Ettől a kutatási irányvonaltól egy esetben szokás eltérni, avagy két adatfelvételi-adatgyüjtési módszert felcserélni, mégpedig a terepmunka és a másodelemzés estében, ahol a már korábban a kutatási témában keletkezett adatok másodelemzése megelőzheti a terepmunka-szakaszt (Letenyei 2004).

A disszertáció témájában végzett kutatás során magunk is Szeged társadalmáról szóló dokumentumok elemzésével kezdjük a kutatómunkát, majd megfigyeléses módszerrel végzett adatgyüjtéssel folytatjuk, melynek során a város különböző területeinek az épített környezetére és a területek társadalmi összetételének különbségeire vonatkozó magas érvényességet biztosító adatgyüjtését végezzük el. Ennek a kutatási szakasznak az eredményei generálják a dolgozat kutatási problémájának megfogalmazását, és azt az elhatározást, hogy a későbbi kutatási szakaszra hipotéziseket fogalmazzunk meg Szeged város társadalmának területi elkülönülésére és annak mérésére magasabb megbízhatóságot biztosító módszereket is alkalmazzunk.

A magasabb mérési módszerek közül az egyik a másodelemzés módszere, ahol a Központi Statisztikai Hivatal Szeged Város teljes lakónépességére vonatkozó népszámlálási adatait elemeztük az elvégzett iskolai osztályok száma, valamint gazdasági aktivitás és az életkor változók bevonásával. A területi-társadalmi különbségeket ezen paraméterek alapján mutatjuk ki számlálótömbök szerinti bontásban a 2001-ben végzett felvétel alapján.

A másodelemzéses kutatási szakaszban két okból esett választásunk kizárólag az iskolai osztályok száma, a gazdasági aktivitás és az életkor változókra:

1. A magyarországi szegregációkutatások eredményei azt mutatták ki, hogy leginkább ezen változók (ezek közül is leginkább az elvégzett iskolai osztályok száma) a meghatározóak a különböző szegregátumok társadalmi összetételében. (Ladányi 2004) 
2. A másik ok az, hogy a népszámlálási adatok a bevonható változók szintjén erre a két magasabb mérési szinten is alkalmazható társadalmi helyzetet meghatározó paraméterre korlátozódnak. ${ }^{4}$

A kvantitatív kutatási szakaszban került sor a mentális térképezéshez szükséges adatok felvételére, ami konkrétan az egyes területekhez kötődő sztereotípiákra, valamint fókuszáltan az alacsony (szegények), illetve a magasabb társadalmi státuszúak (gazdagok) által lakott területek fejekben lévő meghatározására és azok elhelyezkedésre vonatkoztak. Az adatfelvételek három alkalommal: 2007-ben $(\mathrm{N}=2548)$, 2009-ben ( $\mathrm{N}=2575)$ és 2010-ben $(\mathrm{N}=1577)$, Szeged felnőtt lakosságára reprezentatív, személyes kérdezőbiztosokkal végzett kérdőíves vizsgálatban történtek.

A kvantitatív kutatási szakaszok eredményeképp Szeged társadalmának a társadalmi rétegződés két meghatározó strukturális paramétere alapján való térbeli elkülönülését, és annak kiterjedését valamint a szegediek gondolkodásában jelenlévő különböző társadalmi csoportok térbeli elhelyezkedésére vonatkozó mentális reprezentációit elemezzük. Kísérletet teszünk annak bemutatására, hogyan értelmezhető kvalitatív-kvantitatív megközelítés alapján a városi társadalom térbeli elkülönülésének vizsgálata a 2001. évi Népszámlálás adatainak másodelemzésével, valamint megfigyelés és három kérdőíves felmérés adatai alapján. A város egyes területeire, a nagyobb területi egységektől a lehetséges legkisebb területi lehatárolásokig (funkcionális lakókövezet városrész - számláló körzet - számláló tömb) meghatározzuk a területi elkülönülés objektív és szubjektív (mentális disszimiláció) mutatóinak értékét, és ez alapján értelmezzük Szeged belső differenciálódását.

Elemzésünk fö kérdései részben módszertaniak, részben Szeged belső tagozódására vonatkoznak. Módszertani kérdés, hogy a mentális térképezés eszközével kapott eredmények mennyiben térnek el, vagy felelnek meg a kvantitatív adatok által mutatott eredményektől. További módszertani kérdés, hogy a mentális térképezés mint módszer, mennyire használható a városi társadalom térbeli mozgási folyamatainak valamint a városrendezési beavatkozások hatásainak mérésére?

\footnotetext{
${ }^{4}$ A népszámlálási adatok között szerepel még a munkastátusz is, amely a társadalmi rétegződés graduális paraméterei közé, továbbá a nem és a nemzetiségi hovatartozás is, amelyek a nominális paraméterek közé sorolandók (Blau 1976, Angelusz 1999). Ezen változókat azonban a szegregáció kutatások korábbi eredményei alapján és alacsony mérési szintjük miatt nem tartottuk célszerünek bevonni az elemzésbe.
} 
Az elemzésünk során arról igyekszünk képet alkotni, hogy Szeged alacsony és magas státuszú lakosságának a lakóterület jellege szerinti elkülönülése, szegregációja melyik elemzési eljárás során, milyen eltéréseket vagy hasonlóságokat mutat, vagyis hogy a lakossági szegregáció objektív, vagy szubjektív értelmezése mennyiben feleltethető meg egymásnak.

X.2. Első kutatási szakasz: Tereptávoli adatgyüjtés. Dokumentum-és forráselemzés

\section{X.2. Szeged városszerkezeti tagozódása}

Szeged társadalmi-térbeli tagozódásával kapcsolatos dokumentum-és forráselemzés mint adatgyűjtési módszer alkalmazását egy szociológiai tárgyú értekezés során azért láttuk célravezetőnek, mert a város történetének meghatározó eseménye, az 1879-es „Nagy Árvíz” kapcsán született dokumentumok, leírások, társadalomtudományi, szociológiai tanulmányok egyöntetűen utalnak arra, hogy a város fejlődésének történetére és társadalmára, jelentős hatást gyakorolt ez a tragikus esemény. (Lechner 2000, Bálint 1959, Erdei 1971, Bálint 1976, Kovács 2003).

Az elemzett dokumentumok adatai kiemelik, hogy Szeged földrajzi értelemben vett térbeli tagozódását jelentősen meghatározza a táj fekvése, nevezetesen hogy az eredeti domborzat hármas tagoltságú. Ennek következtében 1879 előtt rendre három része épült fel a városnak, az ártérből leginkább kiemelkedő hátságon a későbbi belváros keleti részét alkotó Vár és Palánk, ettől délnyugatra található a mai Alsóváros magja, a harmadik terület pedig a Felsőváros (Bálint 1976:58).

Meghatározó tényező volt a városszerkezet kialakulásában, formálódásában a lakóépület-állomány túlnyomó részét megsemmisítő 1879. évi árvíz és az azt követő újjáépítés, mivel egyrészt Szeged ekkor nyerte el körutas-sugaras szerkezetét (Kovács 2003:6-8), másrészt világosan szétválasztották a város egyes tereinek funkcióját. Megalkották például a korzót, a sétateret, Újszegeden kapott helyet a liget, a különböző terményekhez kötődő piacokat pedig a város egyes helyeire telepítették (Erdei 1971).

Szeged kezdeti kialakulásában tehát inkább a földrajzi adottságok voltak a meghatározóak, a városfejlődésben azonban a legjelentősebb történés az 1879-es nagy árvíz volt. 
A Tisza szinte az egész várost elpusztította, az összesen 5723 házból mindössze csak 265 maradt meg. Az újjáépítés 1880-ban kezdődött meg, Tisza Lajos királyi biztos irányításával. A Lechner Lajos tervei alapján végzett, egész városra kiterjedő újjáépítés következtében a város korábbi szerkezete fizikailag jelentősen átalakult, a városon belüli társadalmi elhelyezkedés tekintetében azonban megőrizte régi mintázatát, annak köszönhetően, hogy a város újjáépítési tervének elkészítése során Lechner kiemelt figyelmet fordított arra, hogy az egzisztenciáját vesztett szegedi társadalom különbözö rétegei, azokon a területeken foglalhassák el új lakóhelyüket, ahol korábban is laktak (Lechner 2000:IX).

„, A város újonnan való felépitésekor különös figyelem volt fordítandó arra is, hogy az épités módja [...] az egyes városrészek lakosainak viszonyaihoz mérten a szigorúbb körülményeknek is megfelejen [...]" (Lechner 2000:6)

A királyi bizottság [...] húszféle minta-terveket rajzolt, még pedig a legegyszerübb igényeknek is megfelelöeket, melyek az épitkezésben megengedhetö egyszerüsités határán belül, a régtöl elfogadott beosztás, söt még az általánosan használt külsö díszités megtartásával úgy a legigénytelenebb, mint a legtehetösebb nép szükségleteivel és szokásaival is számoltak” (Lechner 2000:7)

A tervező és a döntéshozók ezen intézkedése Szeged újjáépülésének esetében gyakorlatilag azt is jelentette, hogy a város javarészt megőrizhette a középkortól kialakult belső társadalmi-térbeli struktúráját.

Ez az újjáépítési stratégia a szegedi társadalom városon belüli elhelyezkedési mintázatára hosszú időre rányomta bélyegét, s erre a társadalomkutatók is többször felfigyeltek: „,Szeged egyetlen város, de mégis annyiféle, ahány darabja van. [..] A belvárosban lakó is, az alsóvárosi is, a Petöfi-telepi is, a szentmihályteleki is szegedi, söt szegröl-végröl a domaszéki, vagy a balástyai is. Csak a térképen vannak ezek a helyek egymás mellett, s egy városi csoportosulás részei, de akár nagyobb földrajzi távolság is lehetne közöttük. Van azért valami, ami együtt és oszthatatlanul szegedi, ez testesül meg a terekben: a Marx téri piacon, a fötéri és Kárász utcai korzóhelyen, a Klauzál téri köveken, a Tisza-parti sétányon, az újszegedi Ligetben és a Dóm téren. Ezek nyilt helyek, itt találkoznak a különféle szegediek és nem szegediek: szavakat, híreket, nézeteket, árukat cserélnek egymás közt, látják egymást és érzik, hogy Szegeden vannak. Utána azonban ki-ki elmegy haza, a maga külön Szegedébe. 
Ezek a lakótelepek és ezek a városrészek olyan sokfélék és annyira elütök, mintha nem is egy város neve alá tartoznának." (Erdei, 1971:69-70)

Az első városrész, amit Erdei említ, a belváros. Ez volt az egykor a palánkon belüli városmag, majd a nagy árvíz után egy akkor korszerü nagyvárosi igényű belváros épült fel. Számos értelmiségi, író, költő, világhírü tudós lakott itt. Erdei leírása szerint, olyan városi lakóhely ez, amely besorolható az európai városok belvárosi lakónegyedeinek sorába. (Erdei 1971)

Alsóváros korábban külön falu volt a Palánkon kívül, és az összeépülés után is külön falusias városrész maradt. A paprika hazája, ahogy Erdei (1971) nevezi: a „paraszt-Szeged”.

Felsőváros is különálló városrészként települt, kívül a Palánkon, hajósok, halászok, fuvarosok, mindenféle iparosok és kereskedö-vásározó népek települtek ide.

Móraváros és Rókus a Budapest felé vezető út mentén alakult ki, nagyrészt munkások telepedtek le itt. Ez lett az első munkásvárosrész, de ma már ez is történeti városnegyed, történetileg a harmadik városrész, ami körülveszi a belvárost. Az árvíz utáni újjáépítés még csak a belvárosi részt érintette. A munkások és a szegényebb kispolgárok akkor Alsóvároson és Felsővároson laktak, majd később összetömörült belölük Móraváros és Rókus, és ezzel bezárult a kör a belváros körül.

Ez a külvárosi övezet azonban hamarosan szük lett a szegedi szegényebb rétegek számára, és az első világháború után munkástelepek sora épült a nagyrészt mély fekvésű, körtöltésen kívül eső, városszéli földeken. Így keletkezett 1919 és 1926 között a Somogyi (ma Petőfi-telep), az Aigner-telep (ma Béke-telep), a Fodor-telep (ma a Tarján-telep része), a Kecskés-telep, a Hattyas és a Baktó; 1930-1936-ban pedig a Tarján-telep és a Gedó. Nagyrészt mély fekvésü, sok helyen talajvízzel fenyegetett helyen, legnagyobbrészt kétszáz négyszögölnyi telkeken városi szegény emberek építették itt fel kiskertes, falusias házaikat, majd 1960 körül állami támogatások segítségével és az itt lakók önerejéből ezek a lakókörzetek korszerüsödtek.

Erdei két nagyobb lakótelepet említ még: az egyik az „Ogyessza”-telep, a másik pedig Tarján. A város szerves részeként említi még az újszegedi kertek övezetét és Szentmihálytelket, a városon belüli falut. 
A várossal összenőtt peremterületekről: Kiskundorozsmáról, Algyőről, Tápéról, Szőregről és Gyálarétről külön tesz említést (Erdei 1971).

A város „darabjai” Erdei felsorolásában nem jelentenek mást, mint a történetileg kialakult városrészeket, melyek közül mindnek megvan a saját neve, és a maga jól elkülöníthető saját társadalma is.

Szeged történetében a következő mérföldkövet 1950-es évek jelentették, ugyanis ekkor a városhoz tartozó hatalmas tanyavilágból kilenc új községet hoztak létre. (Boros 2009). A nagyobb léptékü városfejlesztési intézkedések ebben az időszakban rendre elkerülték Szegedet, mivel politikai okokból nem tartozott a szocialista rendszer által előnyben részesített települések közé. Az 50-es években fellépő lakáshiányt Szegeden emeletráépítésekkel próbálták orvosolni. A szocialista rendszer gátló hatását Szeged városfejlődésére mutatja az is, hogy 1945 és 1956 között mindössze 635 lakás épült, többségük magánépítkezés volt, és a házak nagy része nem tartós alapanyagból készült. (Boros 2009) „,Ugyanebben az időben a város történelmi részének értékes épületei is áldozatul estek a tömbrekonstrukciónak, amely gyakran a rossz állapotban lévö házak lebontását jelentette. Különösen a hatalom által dekadensnek bélyegzett szecessziós épületek estek áldozatul e folyamatoknak." (Boros 2009:454)

Az 1960-as évektől azonban a lakótelepi építkezések kapcsán Szegeden is megindul a tömeges lakásépítés. A politikai hatalom nemcsak a lakásépítések terén éreztette erejét Szegeden, hanem korlátozott szinten ugyan, de Szeged belvárosi tereit is igyekezett átformálni. „Amögött, hogy a Belváros átalakulása nem lett eröteljesebb, a szocialista modernizációs városépitészeti (tértermelési) törekvésekkel szemben álló, tradicionális települési értékeket védö oldal sikere állt, valamint az, hogy Szeged nem volt a rendszer kegyeltje, így a központi törekvések sem voltak olyan eröteljesek, mint más városok (például Szolnok, Pécs) esetében." (Boros 2009:454) A szocializmus lakásépítési programja azonban mind városszerkezetileg, mind pedig társadalmilag átformálta a várost, amelynek legszembetűnőbb elemei a városrészeket elfoglaló lakótelepi negyedek, és ma már az ezzel kapcsolatos társadalmi problémák. Szeged lakosságának rohamos növekedése szükségessé tette az újabb és újabb lakótelepek építését, így az 1962-ben épített Odessza lakótelep után 1965-ben Tarjánban is elkezdődtek az építkezések. Bár Tarján később már nem volt képes befogadni több lakótelepet, az építkezések mégsem álltak le. 
Lakótelepek épültek a szabad területeken, majd gyürü formájában körülvették az egész belvárost is. Az 1970-es években húzták föl a legtöbb lakótelepi épületet, a szocialista lakásépítés időszakában készült tömbök 43\%-át ekkor építették. Az épületek többsége ekkor még téglablokkos technikával épült, a paneltechnológia használata csak a későbbi időszakban volt jellemző. „1975-től kezdődött Felsőváros első ütemének paneles beépitése, illetve ugyanebben az évben Odessza városrészben is elkezdték a téglablokkos lakótelepet panelházakkal böviteni. 1976-tól Makkosházán 3363 lakás épült fel, majd 1977-ben indult meg a Csongrádi sugárút két oldalán az Északi városrész elsö ütemének épitkezése. 1979-ben folytatódott Felsöváros beépitése a második és harmadik ütemmel. 1980-ban kezdödött a mai Rókusi körút mentén az újrókusi lakótelep épitése, amely egészen 1990-ig elhúzódott. Ezzel párhuzamosan 1986-ig a Felsővárosi lakótelep is teljesen kiépült.” (Boros 2009:456)

Az építkezések az 1980-as évek végén, föként pénzhiány miatt abbamaradtak, a város ekkor már „kinőtte” a körtöltés által behatárolt területet. „,Megindult a terjeszkedés kifelé, beolvasztva a telepeket (Klebelsberg, Kecskés, Fodor, Aigner, Gyula-püspök, Szent Mihály, stb.) és a környezö falvakat (Szöreg, Tápé), továbbá Újszeged különbözö részeit.” (Zombori 2004:48) A szocialista rendszer célkitűzései között szerepelt a lakosság létszámának 200000 före való felduzzasztása is. Valószínűleg ennek is köszönhető, hogy 1973-ban Szegedhez csatoltak öt települést (Algyő, Kiskunorozsma, Gyálarét, Szőreg, Tápé), melyek közül Algyő végül 1997-ben népszavazás útján levált Szegedröl. A csatolt települések lakossága növelte ugyan Szeged lakosságának létszámát, de ugyanekkor előidézett olyan jellegü problémákat is, mint a falusias jellegü településrészek alulfejlettsége a városihoz képest. A csatolt falvak lakosai körében még ma is észrevehető egyfajta különállás, mely erre a több mint 30 évvel korábbi folyamatra vezethető vissza.

Az 1989-es fordulat nem csak gazdasági, társadalmi változásokat okozott Szeged életében, de a város térszerkezete is újra jelentős átalakulásokon ment keresztül. A rendszerváltás után a város egyes területei nagy mértékben felértékelődtek, míg más részeknek jelentősen csökkent az értéke. A helyi politika igyekezett befolyást szerezni ezekre a folyamatokra, de az esetek többségében nem volt képes a piaci folyamatok és a befektetői érdekek ellenére érvényre juttatni akaratát. 
A belváros átalakulása, reprezentációs funkciójának erősítése a rendszerváltás után rohamos ütemben kezdődött meg. A szabályozási terv alapján teljesen átalakult a sétáló utca és környéke, az ezekhez a területekhez tartozó bérlőstruktúra. Emellett a szabályozások során még a későbbi városrehabilitációhoz tartozó formai követelményeket is szigorú szabályokkal kötötték meg (Egedy 2009).

A rendszerváltozást követően a népesség területi mintázata is átalakult: láthatóvá váltak az eddig csak látens különbségek a társadalmi csoportok között, sőt a lakáspiac is lényegesen átrendeződött. A szocialista korszakban épült lakótelep presztízse nagy mértékben lecsökkent, ezzel szemben a kertes családi házak, a kevésbé zsúfolt, könnyen megközelíthető belvárosi területek értéke magasabb lett (Egedy 2009). „A népesség területi átrendezödésének részeként a rendszerváltást követően megerösödött egy sajátos, városon belüli urbanizációs folyamat, amely a kiskerti városrészekbe való kiköltözést jelenti.” (Boros 2009:461) A belvárosi területek mellett a szuburbán jellegü településrészek presztízse is emelkedett, így a lakosság egyre nagyobb hányada választotta inkább a kiskertes városrészeket, mint a lakótelepeket. Ezek a kertes területek gyakran nem is számítottak lakóövezetnek, így olcsóbb volt itt építkezni, mint a város privilegizált városrészeiben. Az építkezés jogi szabályozása viszont bizonytalan volt, így egyre nagyobb alapterületü, családi házak lepték el ezeket a területeket (Boros, 2009). Az olcsó telkeken történt építkezések kapcsán a várost övező egykori kiskertes és üdülöövezetben azok a korábban lakótelepi lakásokban élő alacsonyabb státuszúak is kertes családi házhoz juthattak, akik nem engedhették meg a drága városrészekben való építkezést. Ez a folyamat valószínüleg szerepet játszott abban, hogy az utóbbi években a paneles lakótelepek népességmegtartó ereje folyamatosan csökkent ${ }^{5}$. A lakáspiac változásában Szegeden is szerepet játszott, hogy az állami szerep csökkentésével az addigi önkormányzati tulajdonú lakások többsége magánkézbe került, (ráadásul ekkor még jóval piaci áron alul lehetett hozzájutni ezekhez a lakásokhoz) önkormányzati tulajdonban pedig csak a legkevésbé vonzó lakások maradtak. A kiskertek sorsa viszont még nem dőlt el.

Boros szerint: „, hasonló folyamat mehet végbe, mint ami gyakran a dzsentrifikáció esetében is megfigyelhető: az „úttörők” megjelenése után jobb státuszú csoportok is

\footnotetext{
${ }^{5}$ A 2003-as KSH adatok szerint a lakótelepi népességszám a két utolsó népszámlálás között 7 százalékkal esett vissza, míg Szeged teljes népessége alig csökkent (Boros 2009).
} 
beköltöznek a városrészbe, akár még azokat is kiszoritva onnan, akik korábban költöztek oda. A terület felértékelödik - részben ez történt korábban Szegeden Baktóval és vélhetöen hasonló megy végbe jelenleg Újszegeden, a Marostöi kiskertekben is." (Boros 2009:460)

Szeged városszerkezetének tárgyalásakor elengedhetetlen megemlíteni a lakóparkok megjelenését, ,melyek a posztmodern kor tipikus globális társadalmi jelenségei." (Hegedüs 2007:193) A lakóparkok megjelenése az 1960-as, 1970-es évekre tehető, ekkor főként nyugdíjas lakóparkok épültek az USA-ban, de nagyon hamar elterjedtek a középosztály elővárosaiban is. Nyugat-Európában az 1980-as években terjedtek el a lakóparkok, elsőként a mediterrán országok tengerpartjain, majd a szuburbán területeken is. Magyarországon az 1990-es évek második felében jelentek meg a lakóparkok, Szegeden is ebben az időszakban kezdődtek meg az építkezések.

A klasszikus lakópark (gated community) esetében nincs egy általánosan elfogadható definíció. Hegedűs (2007) lakópark-meghatározásait alapul véve a lakóparkok általában:

- Zárt egységet alkotnak, saját bejáratuk van. (Fallal, vagy kerítéssel, esetleg bokrokkal, fákkal vannak elkerítve a kívülállóktól.)

- Különböző szolgáltatásokat nyújtanak az ott élök számára. (biztonsági szolgálat, sportolási lehetőségek, kényelmi szolgáltatások)

- Többnyire a beruházók által létrehozott szervezetek irányítják.

Szegeden egyelöre nincs őrzött, szolgáltatásokat is nyújtó lakópark, többségük inkább modern lakótelepnek tekinthető (Boros-Hegedüs-Pál 2006). A szegedi „lakóparkok” esetében különösen nehéz a definiálás, hiszen nem őrzik őket, és nem nyújtanak semmilyen szolgáltatást, de egyedi tervezésük miatt mégsem sorolhatóak a lakótelepek közé. Többségük barna mezős beruházással készült, általában temető vagy katonai kollégium helyére épültek, elfoglalva így a megmaradt zöld területeket a városban (Hegedűs 2007).

Hegedűs Gábor 2007-es tanulmányában elkészítette Szeged lakóparkjainak térképét, ahol alábbi létesítményeket emelete ki: 
-Alsóváros határán a Vadaspark Lakópark a Szabadkai út és a Körtöltés közelében található, építése 2005-ben kezdődött. A társasházak és a magánházak építése is jellemző ezen a területen, de többségében társasházak találhatóak itt.

- Újrókuson a Harmónia Lakópark épül, itt csak társasházas beépítés folyik. Különlegessége, hogy birtokol bizonyos közös jellemzőket a klasszikus lakóparkokkal, hiszen épületeinek többsége már közös udvarral rendelkezik, melyet kerítéssel választanak el a nem ott lakóktól.

-Rókuson a Franciahögy Lakópark jó példa a beépített területek funkcióváltására, ugyanis az egykori Rókusi temető helyén létesült. A lakópark nagyon sürü beépítésü, egyforma társasházak alkotják. Hegedüs szerint ha a terjeszkedés ilyen mértékben folyik tovább, akkor a Franciahögy és a Harmónia Lakópark hamarosan összeolvad.

- A Marostői Lakóparkot tartja jelenleg Szeged legnagyobb és legszínvonalasabb létesítményének a kutató. A többi lakóparkhoz képest sokkal nagyobb kiterjedésű, beépítése nagyon változatos: magánházak és társasházak egyaránt jellemzőek rá. A környezet szempontjából is szerencsés, hiszen zöld mezős beruházás révén a lakópark kiépítése nem járt temető vagy más létesítmény felszámolásával.

-A Marostői Lakópark közelében a Marostői-kiskertekben tapasztalható egy érdekes folyamat, mely összefüggésbe hozható a lakóparkok elterjedésével: a kiskertek lakói gyakran akadályokat helyeznek el az utcák elején, megakadályozva ezzel, hogy a nem ott lakók áthajthassanak az utcákon.

-Újszegeden a Kállay-liget Lakópark építése 2006-ban kezdődött, sorházas, társasházas és családi házas beépítés egyaránt jellemzi. Környezetében családi házak, a megújult Holt-Maros a hozzá tartozó sétánnyal, valamint a többfajta sportolási lehetőséget biztosító Gellért Szabadidőközpont helyezkedik el, melyek növelik a lakópark vonzerejét.

•Újszegeden a Derkovits utca és a Közép fasor kereszteződésétől délre a Derkovits Udvar nevü lakópark látható, melynek építése jelenleg is folyamatban van. Három négyszintes társasház építését tervezik, melyek földszintjén garázsokat kívánnak elhelyezni. 
Hegedüs szerint rövid időn belül elkezdődhetnek a klasszikus lakóparkok építései is. Szeged belvárosában azonban már nincs elég hely újabb beruházásra, így a jövőben valószínűleg a város peremterületein indulnak meg az építkezések.

A várostörténeti szerkezetváltozások következtében tehát a jelenlegi várostestben négy fö elem kap helyet: a történelmi városrészek, a lakótelepek, az ipari zóna, és a csatolt települések, melyek elhelyezkedése többé-kevésbé a városmagból kiindulva gyürüs térszerkezetet követ, bennük azonban további sajátos karakterrel bíró egységek határolhatóak le. A 2001-es népszámlálás adatbázisában is az alábbi 10 területi egységet meghatározó változó található (funkcionális lakóövezetek), amelyet elemzésünk során mi is használtunk.

Belváros: a történelmileg kialakult szük városmagot alkotó Vár és Palánk köré szerveződő városközpont és a Nagykörút által határolt része Szegednek, ahol a kulturális és egyéb intézmények zöme helyet kap, valamint a közlekedési hálózat sürüsödik.

Hagyományos beépítésü belsö lakóterület: a Nagykörút és a lakótelepek, valamint az ipari övezet által határolt lakóövezet, melynek részei az egymástól a sugárutak által elkülönített Felsőváros, Rókus, Rókus-Móraváros, Móraváros és Alsóváros. Ezen utóbbi két városrész sokáig a legelhanyagoltabbak közé tartozott, azonban az elmúlt évtizedben végbement jelentős fejlesztések következtében lényegesen javult a helyzetük.

Lakótelepek: a város első lakótelepe az Újszegeden a Ligettől délre épített Odessza városrész. Tarján, Felsőváros, Makkosháza, és Újrókus a várost körülölelő Körtöltés mentén létesültek, s jelentősen elkülönülnek, kiemelkednek a hagyományos lakóövezetböl.

Villanegyed: Újszegednek a töltés és a Marostői utca által lehatárolt belső területe, amelynek azonban nem képezi részét az elöbbiekben a lakótelepek között felsorolt Odessza városrész. A terület központiságát, villanegyed jellegét tovább fokozza az ebben a körzetben található városliget, a strand és a gyógyfürdő, továbbá a különféle oktatási-, kulturális- és sportintézmények.

Kertvárosias jellegü lakóövezet: lényegében a városhoz kapcsolódó, a Körtöltésen kívül eső területek: Béke-, Kecskés-, Klebelsberg-, Új-Petőfitelep, Baktó, Újszőreg, valamint Újszeged eddig nem említett területei a Marostő és a Füvészkert környékén. 
Általában még az első világháborút megelőzően megindult az építésük, s azóta is folyamatos fejlődés jellemző.

Falusias jellegü lakóövezet: az 1973-ban Szegedhez csatolt - korábbi városhatáron kívül eső - volt önálló falvak; Tápé, Kiskundorozsma, Gyálarét, az Újszegeden lévő Szőreg valamint Petőfitelep és Szentmihálytelek tartoznak ebbe a területi egységbe. Egyre inkább előtérbe kerül a lakóhelyfunkció, megfigyelhető az ide irányuló kitelepülés, amit a lakásállomány modernizálása is követ.

Belterületi üdülőhelyek: a magas árhullám esetén víz alá kerülő Sárga, Tiszavirág, Tömörkény üdülötelepek, valamint a Kiskundorozsma után elhelyezkedő Sziksós. Elsősorban szezonális pihenési-kikapcsolódási és idegenforgalmi funkcióval rendelkeznek, azonban az eredetileg üdülőnek épült házak egyre inkább szolgálnak állandó lakásul a tulajdonosoknak.

Ipari övezet: a lakótelepektől kiinduló gazdasági zóna a Körtöltés két oldalán. Gyéren lakott településrész, jóllehet található itt két középiskolai és két felsőoktatási kollégium.

Kiskerti üdülök: a város körül helyet foglaló hobbikert-zóna, amelyben részlegesen megtörtént az infrastruktúra kifejlesztése. Ide tartoznak a Marostői kiskertek, Subasa, a Szőregi-, a Tápéi-, a Ballagitói, a Gyálaréti-, a Tompaszigeti- és a Bodomi kiskertek. Az infrastrukturális ellátottság teljessé tételével - a csatornahálózat, a közvilágítás és a szilárd útburkolat kiépítése - ezen területek lakóhelyi funkciója jelentősen elötérbe kerülhet.

Egyéb külterület: Szeged viszonylag nagy kiterjedésű, ritkán lakott határa. (Kovács 2003:7-11) 


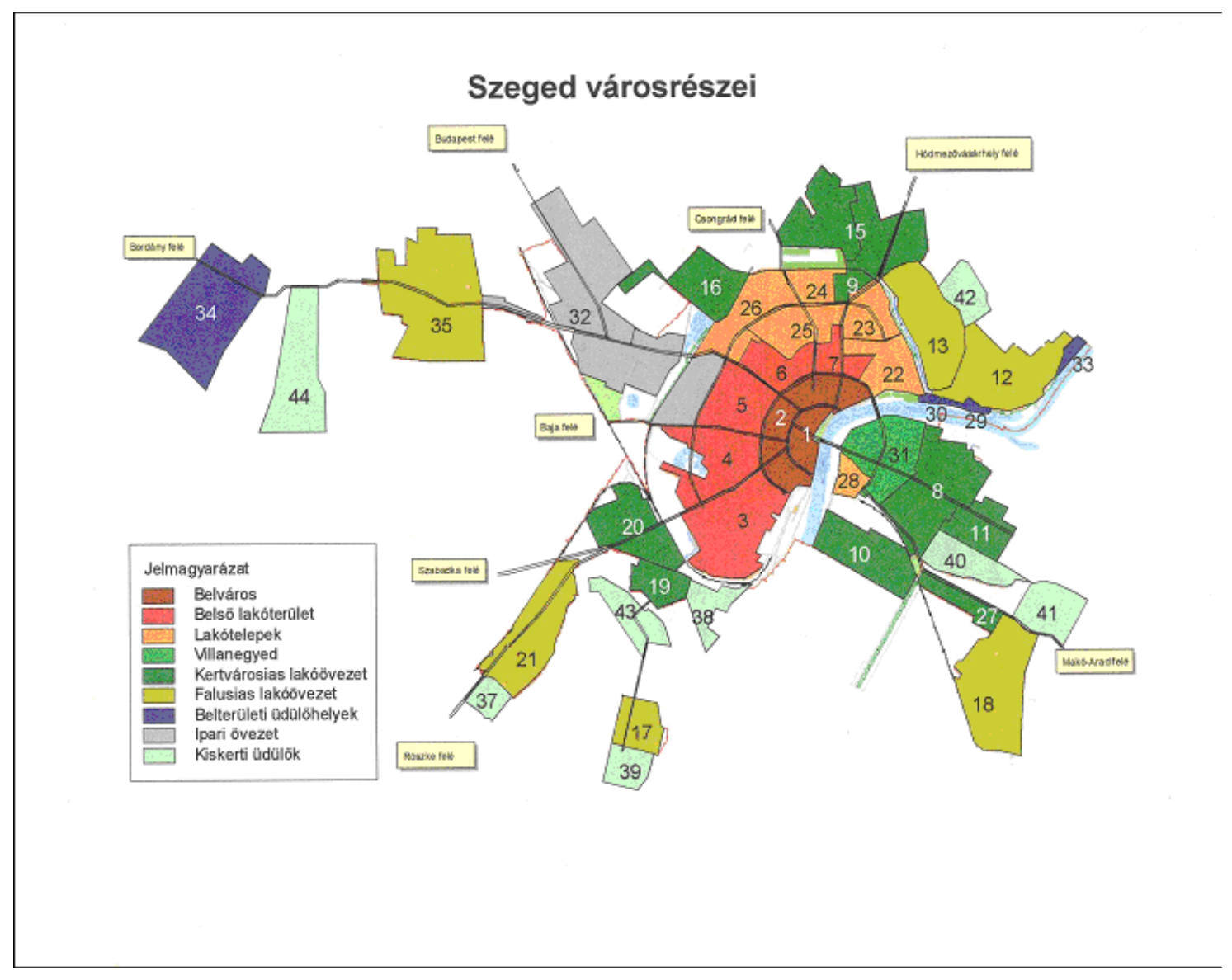

\section{1. térkép: Szeged városrészei}

Forrás: (Kovács 2003)

A város itt bemutatott térbeli egységei nem csupán és nem elsősorban egy-egy szeletei a városszerkezetnek, hanem a település története, kialakulása és fejlődése során többé-kevésbé sajátos jellemzőkkel bíró népességet, társadalmi csoportot tömörítő tömbökként is értelmezhetőek első kutatási szakaszban végzett dokumentum-elemzés eredményeképp.

A belvárosban éltek valaha például az értelmiségiek, az urak és polgárok, és később is a jobb keresetü rétegek lakóhelyéül szolgált, míg a paprikáról elhíresült Alsóváros a paraszti származásúakat tömörítette, amely koncentráció csökkent a tanyák elszakadását és a termelőszövetkezetek létrehozását követően.

Felsővárosban inkább a kereskedők és az iparosok, hajósok, halászok, fuvarosok, Móravárosban és Rókuson pedig túlnyomó részben munkások éltek, azonban ez a terület hamarosan szük lett a szegényebb rétegek számára, így azok a töltésen kívül található Somogyi- (Petőfi-), Aigner- (Béke-), Fodor- (Tarján-), Kecskés-és Hattyastelepen építettek maguknak földből és sárból falusias házakat. Újszeged belső részein a 
polgárok nyaralóházait, külső területein pedig földmüveseket találhattunk. Szőregen vegyes lakosság - termelöszövetkezeti tagoktól a vasutasokon át, vezető állami és társadalmi funkciókat birtoklókig minden foglalkozású - művelte kertjeit, Szentmihálytelek pedig Alsóváros kisparasztok által lakott folytatása volt. Ugyancsak eredetileg paraszti-falusias jellegű volt Algyő és Tápé népessége, Szőreg szerb betelepitettek által lakott földmüvelö, határőrfaluként jelent meg, míg Gyálarét korábbi tanyaszerủen összetelepült részből lett városhoz tartozó lakóteleppé. Kiskundorozsma pedig sokáig önállóságát megőrző kiváltságos tanyás mezőváros volt, nagy agrárproletariátussal, akik kubikosokká váltak (Erdei 1971:70-84).

Egy-egy fentebb meghatározott városrész sajátos jellemzőinek bizonyos mértékü továbbélésére utal, hogy a városban végzett földrajzi-geográfiai kutatások kimutatták a Szegedhez csatolt, korábban önálló falvak különállását, mivel azok továbbra is őrzik régi funkcionális jegyeiket (például az épülő új lakásokhoz kert kapcsolódik, jelenleg is általános a főmunkaidőn kívüli kertgazdálkodás). A kutatások szerint az őslakók nem érzik magukat városi polgárnak és a város lakói sem tekintik a város részének ezen településeket. Az ide kiköltözők átveszik az adott környezetben talált falusias életmódot, a tapasztalatok alapján tehát domináns maradt a falusi vonás (Mészáros 1994:129-136).

A Szeged társadalmi-térbeli mintázatának leírásáról szóló dokumentum elemzése során összességében a fentebb idézett leírások, említett adatok generálták a kvalitatív szakaszban alkalmazott újabb kutatási kérdéseinket, nevezetesen azt, hogy:

1. Szeged jelenlegi térszerkezete ma milyen képet mutat?

2. Mennyire különülnek el az egyes részek a lakóépületek funkciói, fizikai jellegzetességei alapján?

3. Érzékelhető-e valamilyen homogenitás a helyi társadalom összetételére vonatkozóan?

4. A szegediek ma milyen térbeli és társadalmi kategóriákban gondolkodnak a városukat illetően?

Másként fogalmazva és egy konkrét kutatási módszerhez társítva: a szegediek mentális térképén miként jelenik meg a város és a város társadalma, azok milyen részekből, területekből csoportokból társadalmi kategóriákból állnak össze? 
X.3. Második kutatási szakasz: Terepközeli adatgyüjtés. Terepbejárás, megfigyelés, strukturálatlan interjúk

\section{X.3.1. Szeged városszerkezeti tagozódásának kvalitatív vizsgálata}

Az első kutatási szakaszban megfogalmazott kutatási kérdések relevanciájának tesztelésére a továbbiakban két adatgyüjtési módszert alkalmaztunk párhuzamosan: A város bejárása során tett megfigyeléseink mellett, az adott városrészben lakókkal strukturálatlan interjúkat készítettünk. Az interjúalanyok kiválasztásánál az egyszerüen elérhető alanyok módszerét alkalmaztuk (Babbie 2003:205-206), mivel ebben a kutatási szakaszban még nem volt célunk a reprezentatív mintavétel, azonban az interjúalanyok kiválasztásakor törekedtünk arra, hogy lehetőleg különböző demográfiai jellemzőkkel rendelkező adatközlöket sikerüljön megszólaltatni. Megfigyeléseink során, melyeket a 2002-2007. év közötti időszakban folytattunk, mintegy 150-200 rövid beszélgetésre került sor.

A megfigyelés módszerével végzett adatgyüjtés eredményeként azt állapítottuk meg, hogy Szeged épületállománya, a fizikai és funkcionális jellemzők tekintetében ma is többé-kevésbé őrzi a hagyományos városrészi felosztottságát, bár az is érzékelhető, hogy az új épületek mind megjelenésükben, mind lakóinak társadalmi jellemzőit tekintve egyre inkább csökkentik ezt a hagyományos városrészenkénti különbözőséget. A sürü beépítettség miatt ma már a belvároshoz közeli városrészeknél nincs éles határvonal, de minél távolabb jutunk a belvárostól, annál egyértelmübben elkülönülnek az egyes részek. A külső övezetekben például közúti táblák is jelzik a városrészek közötti határt.

Az egykori történelmi városrészek jellegzetességeiket tekintve - az épített környezetet és a társadalmi homogenitás esetében is - egyre inkább elveszítik sajátos arculatukat, és így ennek következtében határaik lassan összeolvadnak. A történelmi városrészek egykori határvonalai egyre inkább csak a fejekben - kognitív térképeken - 
léteznek ${ }^{6}$. Némi eltérést mutatnak ebben a tekintetben azok a városrészek, amelyek egykor önálló települések voltak. Ezen egykor különálló településrészek és a történeti Szeged közötti határvonalak korábban és ma is élesebbek (töltés, vasútvonal, főútvonal), inkább törésvonalként értelmezhetőek, melynek hatása a kognitív térképeken is megmutatkozik.

A városon belül szemmel láthatóan is jól elkülönülő részek leginkább a lakóépületek mentén, az egyes lakóterületek jellege szerint írhatóak le. Megfigyeléseink eredményeképp a város különböző lakóterületeinek morfológiai jellemzői alapján két csoportba sorolhatóak, amelynek az övezeti területi kategória besorolást adtuk, jellegük alapján pedig hat csoportot alkotnak.

\begin{tabular}{|c|c|}
\hline Lakóterület & Lakóövezet \\
\hline Belváros & Átmeneti \\
Lakópark & Lakótelepi \\
Kertváros & Falusias \\
\hline
\end{tabular}

1. táblázat: Szeged különböző lakóterületeinek morfológiai jellemzőik szerinti csoportosítása, saját megfigyelés alapján

A szegediek gondolkodásában azonban a fenti csoportosítás szerinti területi elkülönüléssel hasonlatos lehatárolásokat csak nyomokban találtunk, a belváros és lakópark kategóriák esetében.

A szegediek gondolkodásában az egyes területek elkülönülésére vonatkozóan továbbra is meghatározó kategóriákat alkotnak a különböző, történetileg kialakult valamint csatolt városrészek. A szegediek lakóhelyi identitása - az interjúk alapján kizárólag abban az értelmezésben az identitás fogalmán belül, hogy a város mely területén van a lakóhelyük, leginkább a városrészekhez kapcsolódik. ${ }^{7}$ A lakóparki „,identitás” esetében valószínűleg Szegeden is azok a sajátos jellemzők adhatnak

${ }^{6}$ Erre a kitételre ad majd a későbbiek során magyarázatot az a mentális térképekre vonatkozó kutatási rész, amelyben azt vizsgáljuk, hogy mely városrészekhez az ott élökre vonatkozóan milyen sztereotípiákat társítanak a szegediek.

${ }^{7}$ Ez a megállapítás, a későbbi kvantitatív kutatási szakaszban végzett kérdőíves adatfelvétel során megfogalmazott kérdés magyarázatát adja, nevezetesen, hogy miért úgy fogalmaztuk meg a kérdöíves adatfelvételben szereplő kérdésünket, hogy: Hogy hívják ezt a városrészt, amelyben Ön lakik? 
magyarázatot, amelyek a lakóparkok területi és társadalmi zártságával állnak összefüggésben (Hegedűs 2007, Csizmady 2008, Cséfalvay 2008)

A területenkénti társadalmi homogenitás tekintetében azonban jóval nagyobb változás érzékelhető. Az egykor társadalmi összetételükben csaknem teljesen homogén városrészek mára érzékelhetően heterogenizálódtak. Különösen a korábban és ma is átmeneti övezetként jellemezhető Alsóváros, Móraváros és Rókus esetében tapasztaltuk azt, hogy a területen belüli kisebb lakótömbökben találhatóak csak társadalmilag homogén csoportok - a területre korábban jellemző munkás és paraszt származású, ipari vagy mezőgazdasági munkát végző népesség (Erdei 1971). Az itt említett három városrész jelenleg jól látható dinamikus átalakuláson megy keresztül, a lakóépületek összetételének szempontjából ugyanúgy, mint társadalmi összetételét illetően. A három városrész ebben a tekintetben jelenleg jól láthatóan magában hordozza a leromlott és újjáépülő épített környezetet, és az ezzel párosuló társadalmi összetételben jelentkező különbségeket is, amelyek leginkább a mikro-szegregátumok nagyobb számában mutatkoznak meg. Az egykor ugyancsak homogén társadalmi csoportok lakhelyeként számon tartott Felsőváros estében - az egykori halászok, iparosok által lakott városrészben (Erdei 1971) - már nyomokban sem érzékelhető ez az egykori társadalmi homogenitás.

Kiterjedését tekintve a legnagyobb és lakónépességének társadalmi státusza alapján is leginkább homogén terület a városon belül Újszeged, annak is kimondottan az a része, amely az egykori villanegyedtől Marostőig terjed.

Az itt lakó népesség társadalmi státusza magasabb az átlagosnál, és a lakóépületek fizikai állapota, a lakóterületek környezeti jellemzői nagyobb egybefüggő területi megoszlásban is szemmel láthatóan jobbak.

A kvalitatív elemzési szakaszban megfogalmazódott történeti városfejlődéssel kapcsolatos kérdésfelvetésünket az eredményeink alátámasztják. A mentális térképeken megjelenő kognitív struktúrák határait illetően meghatározóak az adott település szerkezeti és történeti kialakulása, Szeged esetében a különböző városrészek. 
Kutatásunk ezen szakaszának tapasztalatai a további vizsgálódást illetően immár jól körülhatárolták azt a kérdéskört, amelyre a társadalmi-térbeli elkülönülés mint kutatási probléma kapcsán további hipotéziseket lehet megfogalmazni, és egy nagy mintás kvantitatív - magas megbízhatóságot jelentő - adatfelvételt követően azokat tesztelni.

\section{X.4. Harmadik kutatási szakasz: kvantitatív adatok elemzése}

A Magyarországon végzett városi szegregáció-kutatások egyik fő megállapítása az, hogy a klasszikus városszociológiai modellek mentén nem határolható le megfelelőképpen egy-egy szegregátum, a modellek területi „elnagyoltsága” következtében. A különböző rétegképző paraméterek mentén mérhető társadalmi elkülönülés térbeli megjelenítésére használatos kisebb egységek, a városrészek, kerületek, választókörzetek, városrendezési körzetek, számlálókörzetek úgyszintén nem, vagy csak igen korlátozott mértékben alkalmasak a szegregátumok valóságnak megfelelő területi lehatárolására (Ekler-Hegedűs-Tosics 1980, Csanádi-Ladányi 1988, Ladányi 2008). Ennek legfőbb magyarázata az, hogy a különböző társadalmi csoportok különböző nagyságú területeken mutatnak sürüsödést. Leginkább a magasabb társadalmi státuszú csoportok azok, amelyek „a többiekhez képest leginkább (de nem teljesen) térben összefüggö, nagy kiterjedésü területeken találhatóak, még a legalacsonyabb státuszú csoportok lakóhelyei több, egymással össze nem függö, kisebb méretü szegregátumként helyezkednek el." (Ladányi 2008:21)

Az értekezés további részében megvizsgáljuk, hogy a fentebb megfogalmazott állítások Szegedre is érvényesek-e. Szegedi vizsgálatunkat a Ladányi és munkatársai által alkalmazott módszer (Ladányi 2008) a 2001-es népszámlálási adatokra való alkalmazásán kívül a mentális térképes felvétel módszerével bővítjük, így azt is meg tudjuk határozni, hogy a szegediek gondolkodásában a különböző társadalmi csoportok milyen sủrüsödést mutatnak, és ezek a mentális sürüsödési pontok milyen nagyságú területeket fednek le. 


\section{X.4.1. A KSH által Szeged területén lévő szegregátumok lehatárolása, lehatárolt szegregátumok és veszélyeztetett területek bemutatása}

A KSH a 2001-ben végzett népszámlálás adatainak alapján, azokat a területeket minősíti szegregátumnak (szegény szegregátumnak), ahol az aktív korú népességen belül a legfeljebb általános iskolai végzettséggel rendelkezők, és a rendszeres munkajövedelemmel nem rendelkezők aránya mindkét mutató esetében magasabb, mint 50\%. Azokat a részeket pedig, ahol a lakosok számának legalább 40\%-a ugyanezen rétegképző paraméterek szerint alacsony státuszú, veszélyeztetettnek minősíti. (ASZT Szeged 2008). ${ }^{8}$

A KSH ezen adatok alapján a Szegeden szegregátumként nyilvántartott területek közül kettőt emelt ki, és minősített szegregátumnak (ASZT 2008), melyek gyakorlatilag a város két cigánytelepét jelentik:

1. Móraváros: Móravárosi körút - Cserepes utca és a Katona József utca, valamint a Rákóczi út - Gólya utca - Cserepes utca által határolt városrész. A „Cserepes-sor” Szeged azon szegregátuma, amelynél a szegedi adatok, és az önkormányzati adatok is egybehangzóan bizonyítják a szegregátum létét.

2. Kiskundorozsma: 48-as átkötő út - Búza utca - Északi sor Sziksósi út által határolt városrész. Az itt található, bérlakásokból álló komfort nélküli házsor olyan lakóterület, amelynél a szegedi adatok, és az önkormányzati adatok is egybehangzóan bizonyítják a szegregátum létét.

A KSH által nem kiemelten, de szegregátumként nyilvántartott területek 2001-ben az alábbiak:

\footnotetext{
${ }^{8}$ A népszámlálási adatok ezen két társadalmi státuszt meghatározó paraméter szerinti elemzése során, a szegregátumok lehatárolása kapcsán olyan problémába ütköztünk, hogy az adatbázisban nem csak a lakóépületek háztartásainak adatai, hanem a különböző intézmények lakóinak adatai is szerepelnek, akiknél mind az általános iskolai végzettség, mind pedig a rendszeres munkajövedelem tekintetében egyegy koncentrált területen belül a vizsgált változók szerinti kis szórású homogén csoportokat találunk, ezek azonban mégsem minősíthetőek szegregátumoknak. Ezek az adatok ugyanis sok esetben olyan homogén területi egységekre is rámutatnak, mint pl. középiskolai kollégiumok, gyermekotthonok, vagy idősek otthona, ezért az ilyen típusú intézmények adatait külön kell kezelni a népszámlálási adatok területi szegregációra irányuló elemzések során.
} 
1. Tarján: Ürhajós utca - Bölcsőde utca - Budapesti körút által határolt városrész.

2. Északi-város: Margaréta utca - Csongrádi sugárút - Sárosi utca által határolt rész.

Ezek a területek olyan lakótelepi övezetben találhatóak, ahol 2001-2008 között a szociális városrehabilitáció befejeződött, tehát a környező panelházak egyike sincs megjelölve szegregátumként.

\section{X.4.2. A 2001-es népszámlálás adatainak másodelemzése}

Az értekezés témája nem csak a kifejezetten halmozottan hátrányos helyzetü szegedi lakosság objektív adatok alapján mérhető területi elkülönülésére fókuszál, hanem arra is, hogy a szegediek gondolkodásában - mentális térképén, amelyben a szubjektivitás is nagy szerepet játszik az adatközlés során -, hogyan jelenik meg a város társadalmának mintázata, és az milyen összefüggést mutat az objektív adatok alapján megrajzolható társadalmi-térbeli elkülönülést bemutató térképpel. Emiatt szükségét láttuk annak, hogy a 2001-es népszámlálási adatok alapján az egész város területére vonatkozóan egy másodelemzést végezzünk, amely elemzés eredményeit a későbbiek során majd összevetjük a mentális térképes vizsgálat eredményeivel.

A KSH 2001-es népszámlálási adatainak másodelemzésekor négy különböző területi bontásban vizsgáltuk meg ${ }^{9}$ az aktív korú alacsony iskolai végzettségü, munkanélküli (alacsony státusz) valamint az aktív korú, magas iskolai végzettségü, szellemi foglalkozásúak (magas státusz) kategóriájába sorolható szegedi lakosság szegregációs és disszimilaritási mutatóit ${ }^{10}$.

${ }^{9}$ Az adatbázis csoportosító változói erre a négy különböző területi felosztásra adtak lehetőséget.

${ }^{10}$ Az aktív korúak csoportját 18-60 év között, az alacsony iskolai végzettséget 8 általános, ill. annál kevesebb elvégzett iskolai osztályban, határoztuk meg. A szellemi foglakozásba való besorolás kategóriái a következők voltak: törvényhozók, igazgatási, érdekképviseleti vezetők, gazdasági vezetők, egyetemi, főiskolai képzettség önálló alkalmazását igénylő foglalkozások, egyéb felsőfokú vagy középfokú képzettséget igénylő foglalkozások. 


\begin{tabular}{|c|r|r|r|r|r|}
\hline \multirow{2}{*}{ Területi lehatárolás } & \multicolumn{3}{|c|}{ Szegregációs index } & \multicolumn{2}{c|}{ Disszimilaritási index } \\
\cline { 2 - 6 } & Alacsony státusz & Magas státusz 1 & Magas státusz 2 & 1 & 2 \\
\hline $\begin{array}{l}\text { Funkcionális } \\
\text { lakóövezetek }\end{array}$ & 7,43 & 17,31 & 18,76 & 19,76 & 21,48 \\
\hline Városrészek & 13,11 & 20,71 & 22,03 & 27,72 & 29,05 \\
\hline Számlálókörzetek & 27,55 & 27,13 & 28,26 & 35,64 & 36,13 \\
\hline Számlálótömbök & 28,97 & 28,44 & 29,29 & 33,74 & 33,48 \\
\hline
\end{tabular}

2. táblázat: Az alacsony és magas státusz kategóriájába sorolható szegedi lakosság szegregációs és disszimilaritási mutatói területi egységenként

A szegregációs indexek, a különböző státuszú csoportok és a lehatárolt területi egységek nagyságának függvényében eltérő eredményeket mutatnak. Minél nagyobb kiterjedésü egy-egy területi egység, a vizsgált csoportok szegregációs indexei annál kisebbek. Szembeötlő a szegregációs indexek közötti különbség az alacsony és magas társadalmi státuszú csoportok között a legnagyobb területi egységben, azaz a funkcionális lakóövezetek esetében. Ennél a területi lehatárolásnál az a kép rajzolódik ki, hogy a magas státuszúak jobban szegregálódnak, az alacsony státuszúak pedig sokkal kevésbé. Ugyanakkor, ha a területi egység szerinti szegregációs indexek „range-eit” csoportonként összevetjük, látható, hogy azok jelentős eltérést mutatnak. A magas társadalmi státuszúak szegregációs indexének legnagyobb és legkisebb területi egység közötti különbsége $(11,13$ és 10,53) az alacsony státuszúak ugyanezen mutatójának $(21,54)$ csak közel fele. Ez azt jelenti, hogy a területi lehatárolás nagysága erősebben befolyásolja az alacsony státuszú csoport szegregációs indexeinek mértékét. A szegedi területi lehatárolások esetében pedig, a számlálókörzet szintü lehatárolás az az egység, ahol az alacsony $(27,55)$ valamint a magas státuszúak $(27,13$ és 28,26$)$ szegregációs indexeinek értékei közelítenek egymáshoz. Tehát a szegregációs görbe nagy területi lehatárolás esetén még $\mathrm{J}$ alakú, azonban a területi egységek összehúzása következtében Szegeden szinte U alakúra változik. Szegeden tehát nem rajzolódik ki olyan markáns J alakzat a területi elemzések szintjének csökkentésével sem, mint Budapesten vagy nagyobb európai városokban (Ladányi 2005:147), melynek magyarázata elsősorban a lakosságszámban keresendő. 
A magas társadalmi státuszúak esetében két csoportot képeztünk az elemzés során, mivel felmerült az a problémalehetőség, hogy a legmagasabb társadalmi státuszúak csoportjának (magas státusz 1) határait talán túl tágan húztuk meg, mivel ide soroltuk az egyéb felsőfokú vagy középfokú iskolai végzettséget igénylő meghatározás alá eső foglalkozásokat is. Ez azt eredményezhette, hogy az alacsony területi elkülönültséggel jellemezhető középrétegek szegregációs indexeit hasonlítottuk össze a legalacsonyabb státuszúak indexeivel. Ahhoz, hogy megbizonyosodjunk róla, hogy magas státuszú csoportokba sorolt ezen kategória mennyire befolyásolja az eredményeinket, létrehoztunk egy olyan magas státuszú csoportot (magas státusz 2), amelyböl kivettük egyéb felsőfokú vagy középfokú képzettséget igénylő foglalkozásokat és erre a csoportra is kiszámítottuk a szegregációs és disszimilaritási indexeket. Az eredmények nem változtak számottevően.

Szegeden 2001-ben, a legkisebb kiterjedésü területi lehatárolás esetében (számlálótömb) az alacsony státuszú lakosság szegregációs indexe $(28,97)$ közel azonos a magas társadalmi státuszú népesség szegregációs indexével (28,44 és 29,29).

A népszámlálási adatok alapján végzett elemzésünk eredményei és a szegregációs görbe nagymérvü változásai tehát Szeged estében is alátámasztják azokat a megállapításokat, melyek szerint a társadalmi hierarchia alján elhelyezkedők térbeli elkülönülést jelző indexei - az általában használatos, viszonylag nagy kiterjedésű területi lehatárolások esetében (funkcionális lakóövezet, városrész) - alacsonyabbak, mint a hierarchia tetején lévőknél. Vizsgálatunk is jól láthatóan alátámasztja, hogy ez a tétel kiváltképp igaz akkor, ha az elkülönülést jelző indexet nagyobb területi egységekre vetítve határozzuk meg, melyek a területen belüli társadalmi heterogenitás következtében elfedik, láthatatlanná teszik a kisebb területi egységekben egyébként létező és ott koncentrálódó szegregációt. Ennek oka, hogy a magas státuszúak akaratuk szerint koncentrálódhatnak, meg tudják azt tenni, hogy az általuk preferált környéken választanak maguknak lakóhelyet, míg a szegények erőforrásaikból adódóan erre képtelenek, ezért mikro-szegregátumokba kényszerülnek, és kisebb területi egységeket lefedve ott koncentrálódnak (Ladányi 2007:199-215). 
A különböző területi lehatárolások szegregációs indexeit alkotó mutatók véleményünk szerint részletesebb elemzésre is érdemesek, mégpedig abból a szempontból, hogy ezek a mutatók milyen értéket vesznek fel az egyes lehatárolásokat alkotó részterületek esetében, mennyire esnek egybe, és milyen mértékben foglalják magukba a KSH által szegregátumként, illetve veszélyeztetetként meghatározott területeket.

A szociológiai megközelítésü területi elemzések egyik leggyakrabban alkalmazott módszere a Duncan házaspár által kidolgozott szegregációs index-számítás, ahol egyegy területi egységre vonatkozóan egy kiemelt csoportot az összes többi csoport eloszlásával vetünk egybe (Duncan-Duncan 1973, 2000, Csanádi-Ladányi 1992:94 idézi Csizmady 2003; Németh 2005). Az adott területre vonatkozóan a két csoport arányai különbségének abszolút értékét vesszük, és azt osztjuk el 2-vel.

Ez a módszer tökéletesen alkalmas arra, hogy meghatározzuk az egyes területre vonatkozó szegregáció mértékét, viszont az összetevők kommutativitása következtében a végeredmény nem ad közvetlenül információt a szegregációs indexet alkotó jellemzőkre, így példának okáért arra sem, hogy egy vizsgált területi egységen belül a magas szegregációs indexet mely csoport nagyobb aránya okozza? Ahhoz, hogy ezen információk birtokába jussunk, meg kell vizsgálnunk minden egyes területre vonatkozóan a szegregációs indexet kitevő területrészekre vonatkozó mutatók valós értékét. A valós értékek előjelei már egyértelmü információval szolgálnak arra vonatkozóan, hogy az adott területen milyen jellegü, mely csoport irányába mutató a szegregáció mértéke.

A funkcionális lakóövezetek alapján történő lehatároláson belül a 2001-es népszámlálási adatok alapján a legmagasabb szegregációs mutatóval a „Falusias lakóövezet” rendelkezik $(-2,13)$. A városrészre vonatkozó mutató valós értéke negatív előjelü (3. táblázat), ami azt mutatja, hogy az övezetben az alacsony státuszú népesség felülreprezentált a teljes sokaság arányaihoz képest, vagyis a népesség alacsonyabb státuszú része koncentrálódik elsősorban ezen a területen. Hasonló a helyzete a belvárosnak is, amely a szegregációs mutató értéke szerint $(1,51)$ a második a funkcionális lakóövezetek közötti rangsorban, de a mutató valós értéke ennél a területnél már pozitív (3. táblázat). 


\begin{tabular}{|l|r|l|}
\hline Városrész & Alacsony státuszúak szegregációs indexének valós értékei & SI \\
\hline Falusias laköövezet & $-2,13$ & 2,13 \\
\hline Hagyományos belső lakóterület & $-0,68$ & 0,68 \\
\hline Egyéb külterület & $-0,64$ & 0,64 \\
\hline Kiskerti üdülök & $-0,24$ & 0,24 \\
\hline Belterületi üdülöhelyek & $-0,03$ & 0,03 \\
\hline Lakótelepek & 0,20 & 0,20 \\
\hline Ipari övezet & 0,26 & 0,26 \\
\hline Kertvárosias lakóövezet & 0,65 & 0,65 \\
\hline Villanegyed & 1,09 & 1,09 \\
\hline Belváros & 1,51 & 1,51 \\
\hline & 0,00 & 7,43 \\
\hline
\end{tabular}

3. táblázat: Az alacsony státuszúak szegregációs indexe funkcionális lakóövezetenként Szegeden a 2001-es népszámlálás adatai alapján

A város antiszegregációs tervdokumnetációjában lehatárolt területek (ASZT 2008), amelyek a belső lakóterületi funkcionális lakóövezetbe esnek, mint a Móraváros: Móravárosi körút - Cserepes utca és a Katona József utca valamint a Rákóczi út - Gólya utca - Cserepes utca által határolt városrész, amelynek szegregációs mutatója $(0,68)$, így csak a negyedik helyen szerepel a területegységenkénti rangsorban. Ha a terület szegregációs mutatójának valós értékét nézzük $(-0,68)$, akkor már jobban kifejeződik a szegregátum hatása, de a városrész még így is csak a második helyet foglalja el az alacsony státuszúak túlreprezentáltságára vonatkoztatott rangsorban. Másodelemzésünk eredményei tehát alátámasztják a nagy területi egységekre vonatkozó ilyen jellegü vizsgálatok azon fő módszertani problematikáját, mely a nagy területi kiterjedéssel járó nagyobb mértékü heterogenitás torzító hatásaira mutat rá (Ekler-Hegedűs-Tosics 1980, Csanádi-Ladányi 1988, Ladányi 2008).

A különböző területi lehatárolások mentén kiszámított szegregációs indexek alapján, tehát világossá válik, hogy Szegeden belül a „szegény-szegregátumok” jellemzően kisebb tömbökben helyezkednek el. Ezt a rendelkezésünkre bocsátott adatbázis másodelemzése során számolt szegregációs indexek értékei is alátámasztják, mivel az adatbázis által használható legkisebb területi aggregátumban - a számlálótömbökben - a legmagasabb a mutató értéke (2. táblázat).

Az alábbi térképen piros színnel jelöltük meg azokat a számlálótömböket, ahol a legfeljebb 8 általános iskolai végzettségü, aktív korú, munkanélküli lakosság aránya az összes aktív korúak számához mérten a felső decilisbe esett, zöld színnel pedig azokat, 
ahol a felsőfokú iskolai végzettséggel rendelkező, szellemi foglakozású aktív korúak aránya, esett a felső decilisbe az összes aktív korúak számához mérten.

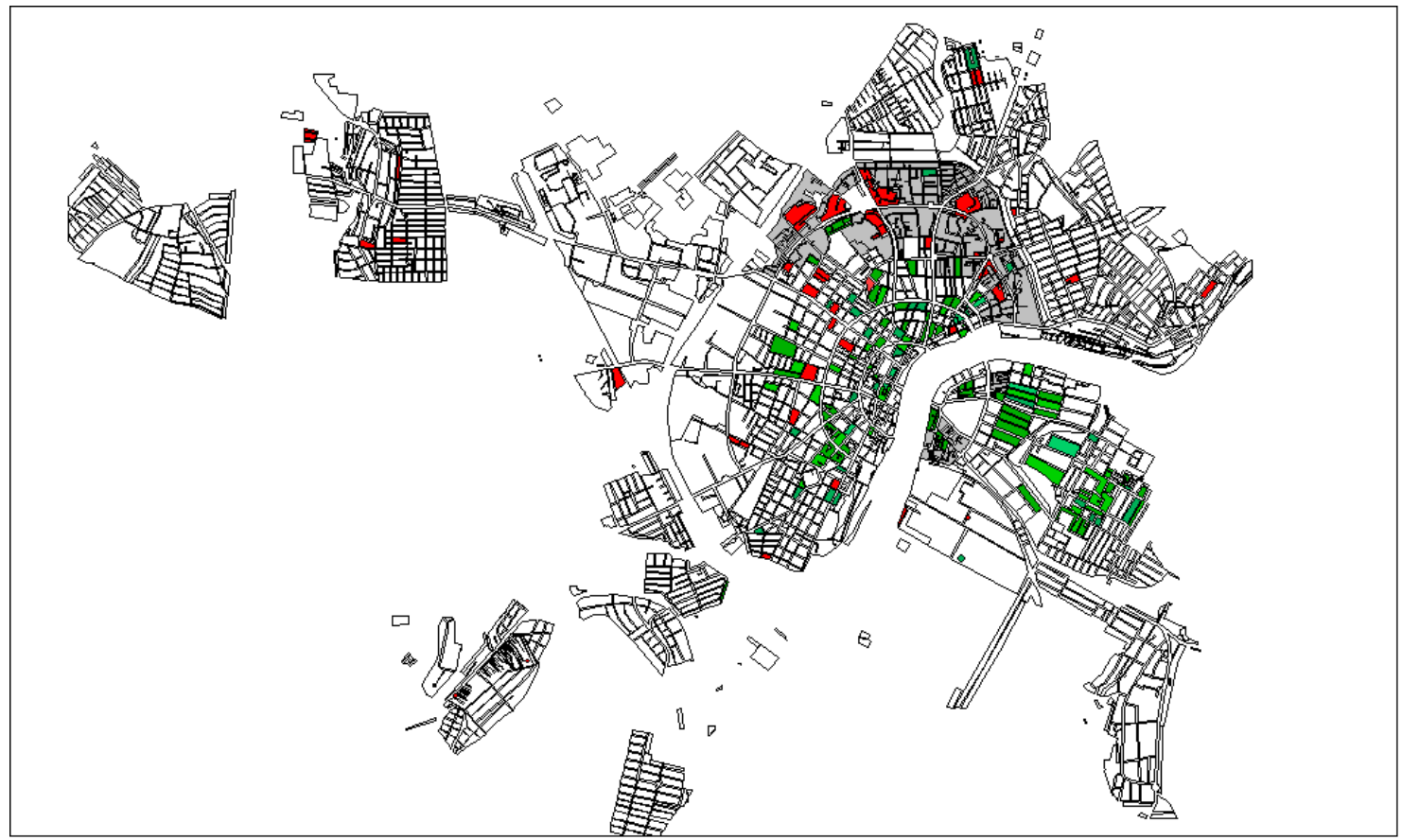

2. térkép: A legfeljebb 8 általános iskolai végzettségü, aktív korú, munkanélküliek (piros) és a magas iskolai végzettségü, szellemi foglalkozásúak (zöld) aktív korúakon belüli aránya szerint sorba rendezett számlálótömbök legfelső decilisei Szegeden 2001-ben (saját szerkesztés)

A térkép jól szemlélteti, hogy az alacsony státuszú lakosság területi mintázata valóban nem alkot egybefüggő területi egységeket, hanem a város számos pontján - ha városökológiai övezetrendszerben gondolkodnánk, még azt is mondhatnánk, hogy a közbülső gyürüben - kisebb tömbökben nem egybefüggően helyezkedik el.

Az általunk magas társadalmi státuszúnak tekintett csoport területi elhelyezkedése ezzel szemben a térképre vetítve is láthatóan nagyobb homogenitást mutat.

Az alacsony státuszúak területi elhelyezkedésének esetében az is észrevehető, hogy 2001-ben az egyes területeken sürüsödési pontok rajzolódnak ki, amelyek a lakótelepi övezetben találhatóak ${ }^{11}$. Ezek a lakótelepeken kirajzolódó sűrüsödési pontok azok, amelyek a KSH által nem kiemelten, de szegregátumként nyilvántartott területként szerepeltek 2001-ben, és amelyekre korábban már utaltunk. Ezeken a területeken 2001-

\footnotetext{
11 A lakótelepi részeket a térképen szürke színnel emeltük ki.
} 
2008 közötti a szociális városrehabilitáció befejeződött, ezért Szeged város antiszegregációs tervében 2008-ban már nem szerepelnek a szegregátumként említett területek között (ASZT, 2008:6-11).

Amennyiben az általunk megrajzolt térkép lakótelepi övezeteire újból rátekintünk, azt is észrevehetjük, hogy a lakótelepi tömbökön belül vannak olyan részek, ahol arányaiban a magas társadalmi státuszú lakosság alkot többséget. Ebből arra következtethetünk, hogy Szeged esetében ezekre a területekre vonatkozóan helytálló lehet az az állítás, hogy: „, az 1970-es évek közepétöl - elsősorban a „félpiaci” és „piaci” kategóriákba sorolható lakásosztályok szaporodásának és új lakótelepekre való behatolásának tulajdonithatóan - figyelemre méltó szegregálódási folyamatok indultak be, és ugyancsak a fenti okok következtében, a lakótelepek egymás között is erös differenciálódásnak indultak” (Ladányi 2008:17).

Elemzésünk következő részében Ladányi János korábban Budapesten végzett hasonló jellegü kutatási eredményeinek szegedi érvényességét teszteljük, amelyek a szegregációs indexek területi lehatárolásával kapcsolatos érzékenységére utaltak, és amelyek bebizonyították, hogy a klasszikus ökológiai modellek alapján nem lehet valós képet alkotni a városok társadalmi térbeli mintázottságáról (Ladányi, 2008).

Csanádi és Ladányi által alkalmazott szórásnégyzetösszeg-felbontás módszerével (Csanádi-Ladányi, 1988; Ladányi, 2008) megvizsgáljuk, hogy az általunk használt - a KSH népszámlálási adatok változói mentén lehatárolt - területi modellek mekkora magyarázó erővel bírnak az elemzésbe bevont két társadalmi csoport szóródását illetően.

A területi modellek legmagasabb magyarázó ereje az általunk vizsgált két különböző csoportnál, a legkisebb kiterjedésű területrészek esetében is mindössze a teljes szórásnégyzet 7\%-át magyarázta (4. táblázat), ráadásul ez a „legjobb” eredmény a magas társadalmi státuszú csoport számlálótömbönkénti szóródására vonatkozik, amely státuszcsoportra egyébként is a legjellemzőbb az összefüggő területi elkülönülés (2. térkép). Ezt a jellemzőt egyébként a különböző modellek szóródását jelző értékek is mutatják, ahol látható, hogy a megmagyarázott hányad értéke a harmadik területi szintnél megduplázódik (3. táblázat). 


\begin{tabular}{|c|c|c|c|}
\hline Területi lehatárolás & $\begin{array}{c}\text { Teljes } \\
\text { szórásnégyzet } \\
\delta^{2} \\
\end{array}$ & $\begin{array}{c}\text { Csoportok közötti } \\
\text { szórásnégyzet } \\
\delta_{\mathrm{K}}^{2} \\
\end{array}$ & $\begin{array}{c}\text { Megmagyarázott } \\
\text { hányad } \\
\delta^{2}{ }_{K} / \delta^{2} \\
\end{array}$ \\
\hline $\begin{array}{l}\text { Funkcionális } \\
\text { lakóövezetek }\end{array}$ & \multirow{3}{*}{13765,120} & 277,341 & 0,020 \\
\hline Városrészek & & 426,861 & 0,031 \\
\hline Számlálókörzetek & & 916,031 & 0,066 \\
\hline Számlálótömbök & 13712,940 & 1039,686 & 0,075 \\
\hline
\end{tabular}

4. táblázat: A magas iskolai végzettségü, szellemi foglalkozásúak aktív korúakon belüli aránya területrészek szerinti szóródásának felbontása

Az alacsony társadalmi státuszú csoportok esetében a népszámlálási adatokhoz illesztett különböző területi modellek még kisebb magyarázó erővel bírnak a csoport szóródását illetően. Az alacsony társadalmi státuszú csoport szóródását gyakorlatilag egyik területi modellel sem lehet magyarázni, mivel a legerősebb magyarázó erővel bíró, legkisebb területi egységekre építő modell magyarázó ereje is mindössze $2,7 \%$.

\begin{tabular}{|c|c|r|r|}
\hline Területi lehatárolás & $\begin{array}{c}\text { Teljes } \\
\text { szórásnégyzet } \\
\delta^{2}\end{array}$ & $\begin{array}{c}\text { Csoportok közötti } \\
\text { szórásnégyzet } \\
\delta^{2}{ }_{\mathrm{K}}\end{array}$ & \multicolumn{2}{|c|}{$\begin{array}{c}\text { Megmagyarázott } \\
\text { hányad } \\
\delta^{2}{ }_{\mathrm{K}} / \delta^{2}\end{array}$} \\
\cline { 1 - 2 } $\begin{array}{c}\text { Funkcionális } \\
\text { lakóövezetek }\end{array}$ & \multirow{2}{*}{1371,951} & 1,234 & 0,000 \\
\cline { 1 - 1 } Városrészek & & 2,568 & 0,001 \\
\cline { 1 - 3 } Számlálókörzetek & & 22,968 & 0,016 \\
\cline { 1 - 3 } Számlálótömbök & 1366,036 & 37,119 & 0,027 \\
\hline
\end{tabular}

5. táblázat: A legfeljebb 8 általános iskolai végzettségü, aktív korú, munkanélküliek aktív korúakon belüli aránya területrészek szerinti szóródásának felbontása

A KSH által lehatárolt szegregátumok meghatározása (ASZT, 2008), és az általunk végzett másodelemzés eredményeinek összevetése Szeged esetében is alátámasztja azt, hogy az eltérö léptékü területi csoportosítások révén nyert aggregátumok heterogének, bennük szükségszerüen további homogén területek különíthetők, el a különbözö társadalmi rétegek - kimondottan az alacsony társadalmi státuszú népesség - egy tömbben elhelyezkedő lakóhelye szempontjából (Ekler-Hegedűs-Tosics 1980, CsanádiLadányi 1988, Ladányi 2008). 
Az eredmények alapján kijelenthetjük, hogy a népszámlálási adatokhoz rendelt területi lehatárolások egyike sem alkalmas arra - magyarázó erejüket tekintve -, hogy ezekre a területi modellekre vetítve a társadalmi-térbeli elkülönülés városon belüli mintázatát a valóságnak megfelelően be tudjuk mutatni.

Ahhoz, hogy ezt meg tudjuk tenni, további adatok elemzésre való bevonására amelyre az általunk hivatkozott Szeged Megyei Jogú Város Antiszegregációs Tervében is sor került a különböző önkormányzati és segélyezési adatok felhasználásakor továbbá ,, sok-sok terepmunkára van szükség” (Ladányi, 2008:41).

X.5. Elemzési kísérlet az objektív és szubjektív adatok mentén. A területi statisztikai adatok és a mentális térkép összevetése

Kutatásunk ezen fázisában három, 2007-ben, 2009-ben és 2010-ben végzett, Szeged felnőtt lakosságára nézve reprezentatív kérdőíves vizsgálatban vettünk fel mentális térképes adatokat, amelynek alapvetően két célja volt:

Egyrészt, hogy megvizsgáljuk azt, hogy a szegediek kognitív térképein léteznek-e társadalmi jellemzőiket tekintve elkülönülő területek, és ha igen ezek a területek elhelyezkedésüket illetően milyen mértékü azonosságot mutatnak a 2001-es népszámlálási adatok alapján végzett, társadalmi-térbeli elkülönülést vizsgáló elemzésünk eredményeivel, másrészt annak vizsgálata, hogy az objektív adatok alapján meghatározható szegregátumok a hozzájuk kötődő sztereotípákon keresztül fejtenek-e ki valamilyen hatást, és ha igen, akkor ennek a hatás milyen mértékü.

A kutatás azon módszertani problémájával, hogy hat illetve nyolc évvel későbbi, mintavételes adatfelvételek eredményeit hasonlítjuk össze egy népszámlási adatbázissal, természetesen magunk is tisztában voltunk, mivel azonban a 2001-es népszámlálási adatok voltak ekkor - és még jelenleg is - a legutolsó megbízható statisztikai adatok az egyes városrészekröl, nem használhattunk mást. Annak tesztelése érdekében, hogy a mentális térképezés mint módszer, mennyire lehet alkalmas a térbeli-társadalmi változások mérésére, a fentebb vázolt módszertani problémák ellenére is érdemesnek találtuk elvégezni ezt a kísérletet. ${ }^{12}$ A kísérlet elvégzése mellett való döntésünket

${ }^{12} \mathrm{Az}$ általunk kidolgozott és alkalmazott adatfelvételi és elemzési módszer használhatóságával kapcsolatosan a területi-társadalmi egyenlőtlenségek alakulásának mérését illetően a 2011-es 
megerősítették a korábbi kutatási szakaszban, bemutatott város-rehabilitációs intézkedésekre vonatkozó adatok is. Az adatok összehasonlíthatóságának módszertani problémája ellenére is úgy láttuk, hogy az egyes, korábban szegregációval veszélyeztetett területek vonatkozásában, az intézkedés óta eltelt idő figyelembe vétele mellett a mentális térképezés módszerével érdemes megvizsgálni a beavatkozás társadalmi sikerességét.

A beavatkozás ténye ugyanis adott, és véleményünk szerint, amennyiben a beavatkozás fejtett ki társadalmilag is érzékelhető hatást, annak jelentkeznie kell a mentális térképeken.

Szeged városára vonatkozó mentális térképes adatgyüjtésünk módszere tisztán kvantitatív jellegü volt, melynek során az egyes városrészekhez kapcsolódó véleményekről és sztereotípiákról gyüjtöttünk adatokat. A kutatásunk ezen szakaszában megfogalmazott kutatási kérdések és logikai következtetések az alábbiak voltak:

1. Létezik-e olyan kognitív területi struktúra, amely mentén leginkább leírható Szeged?

2. Ha létezik kognitív területi struktúra milyen részekböl, alapegységekböl tevödik össze?

3. A kognitiv térképek mennyire pontosan reprezentálják a térbeli valóságot a különbözö társadalmi csoportok területi elkülönülése kapcsán?

4. Amennyiben a kognitív térképek jól reprezentálják a térbeli valóságot, akkor a városról a városlakók fejében kialakult vélemények változása mentén jól leírhatóak-e a társadalmi-térbeli változások is?

5. Amennyiben a városlakók fejében kialakult vélemények változása mentén jól leirhatóak a társadalmi-térbeli változások, akkor ezek változások milyen idötávban jelennek meg a városlakók fejében kialakult kognitív térképeken?

népszámlálás adatainak hasonló módszerrel történő elemzésekor rendelkezünk majd több információval, amikkor is majd a két különböző módszer használatára egy azonos adatfelvételi évben is elöször sor kerülhet. 
A második szakaszban (VII.3 fejezet) végzett terepmunka - terepbejárás, strukturálatlan interjúk készítése - során világossá vált, hogy a szegediek a város területeinek meghatározásakor városrészekben gondolkodnak, azaz a kognitív térképeken az egyes területi egységek tekintetében a történeti városrészek elnevezése a leggyakoribb.

Ezen kutatási szakasz logikailag is első általunk feltett kutatási kérdésére tehát, hogy létezik-e olyan kognitív területi struktúra amely mentén leginkább leírható Szeged, és milyen részekből, alapegységekből tevődik össze, azt a válasz kaptuk, hogy a városlakók fejében létezik ilyen, és a kognitív területi struktúrát a városrészek képezik. A további kutatási szakaszban, nevezetesen a kérdőíves adatfelvétel mérőeszközének elkészítésekor, ezért a részben zárt, erre vonatkozó kérdéseknél 2007-ben és 2009-ben a kategóriákat ezen kognitív struktúra alapegységei, vagyis a történeti városrészek nevei alkották.

Az adatfelvételek során az összehasonlíthatóság végett csak két társadalmi státuszcsoportra, alacsony (szegények) és magas (gazdagok), valamint arra a kérdéskörre fókuszáltunk, hogy a megkérdezettek szerint ezen kognitív területi struktúra szerint (amelynek érvényességét korábban teszteltük) elkülönülnek-e olyan területek, ahol inkább szegények, illetve gazdagok élnek, és ha igen, akkor melyek ezek a városrészek.

2007-ben a megkérdezettek 90,6\%-a (2000 fö), 2009-ben 91\%-a (2082 fö) válaszolt úgy, hogy véleménye szerint vannak olyan városrészek, ahol inkább a szegények laknak. A magasabb társadalmi státuszúak lakóhelyi elkülönülésére vonatkozó kérdésre még egyöntetübb válaszok születtek a két adatfelvétel során. 2007ben a válaszadók 97,2\%-a (2326 fó), 2009-ben pedig 96,7\% (2364 fó) adott olyan választ, hogy vannak Szegeden olyan városrészek, ahol inkább a gazdagabbak laknak.

Az alacsony és magas társadalmi státuszúak városon belüli lakóhelyi elkülönülésének létezésére vonatkozó említési gyakoriságok között ugyan nincs számottevő különbség, azonban véleményünk szerint ez a kis különbség is utal a térbelitársadalmi elkülönülés korábban részletesen kifejtett magyarázatára, nevezetesen arra, hogy más városok mellett Szegeden is a magas társadalmi státuszú csoportokra jellemző a koncentráltabb, nagyobb területi egységet lefedő homogén elkülönülés, melynek okán 
több kognitív térképen jelenik meg a magas státuszú csoport területi elkülönülésének lenyomata.

Az alacsony státuszú csoportok területi elkülönülésére vonatkozó kisebb említési gyakoriságnak ellentétes előjelű hasonló magyarázatát véljük, amely még egy lehetséges magyarázattal is bővíthető, nevezetesen a mindennapi élet során tett városon belüli mozgás és a láthatóság magyarázatával. ${ }^{13}$ A kognitív térképeken ezekkel a területekkel kapcsolatosan nem minden ember fejében alakulnak ki konkrét tapasztalatokon alapuló képzetek, mivel csak ritkán vagy egyáltalán nem járnak ezeken a területeken. A szegénység a területi elhelyezkedése kapcsán is több városlakó előtt rejtve marad, így annak hollétéről is kevesebbeknek van valós tapasztalatokon nyugvó tudása.

A 2010-es adatfelvétel során újra - immáron egy nagymintás adatbázison ( $\mathrm{N}=1577)$ - vizsgáltuk a történeti városfejlődéssel kapcsolatos kérdésfeltevésünket, vagyis azt, hogy a szegediek kognitív területi struktúrája mennyire városrészközpontú. A kérdöív szegények és gazdagok lakóhelyére vonatkozó zárt kérdését megváltoztattuk úgy, hogy nem azt kérdeztük, hogy „Ön szerint Szegeden van-e olyan városrész ahol, szegények/gazdagok laknak?”, hanem nyitott kérdésben azt tettük fel, hogy „Ön szerint Szeged mely területén laknak szegények/gazdagok?” A válaszadó így olyan területi meghatározást adhatott, amilyet gondolt. A kapott válaszokat ezután egy dummy változóban kódoltuk aszerint, hogy a nyitott kérdésre adott válaszok városrészt (1), vagy nem városrészt $(0)$ említettek.

2010-ben a megkérdezettek 79,6\%-a nevezett meg olyan területet, ahol véleménye szerint szegények, 92,3\%-a pedig olyan területet, ahol gazdagok laknak a városban.

A kapott válaszok megoszlása újra alátámasztotta azt, hogy a szegediek többsége városrészekben gondolkodik, hiszen a szegények lakóhelyének meghatározásakor a kérdésre válaszolók 74,5\%-a a gazdagok lakóhelyének megnevezésekor pedig 95,4\%-a városrészt nevezett meg.

\footnotetext{
${ }^{13}$ Manchesterben végzett városleírása során már Engels is rámutatott arra (Engels, 1845), hogy a szegények lakóhelyei a város eldugottabb részeiben, távol a föbb közlekedési útvonalaktól helyezkednek el zárványszerüen. Ladányi és munkatársai pedig arra hívták fel a figyelmet, hogy az alacsony társadalmi státuszú lakosság e zárványszerü elhelyezkedése erősen szórt, nem homogén területi mintázatban jelenik meg (Ekler-Hegedűs-Tosics, 1980; Csanádi-Ladányi, 1988; Ladányi, 2008).
} 


\begin{tabular}{|l|l|r|r|r|r|}
\hline \multicolumn{2}{|c|}{} & Gyakoriság & $\%$ & Érvényes \% & Kumulatív \% \\
\hline \multirow{3}{*}{ Érvényes } & nem városrészt említett & 324 & 20,5 & 25,5 & 25,5 \\
\cline { 2 - 6 } & városrészt említett & 947 & 60,1 & 74,5 & 100,0 \\
\cline { 2 - 6 } & Érvényes összesen & 1271 & 80,6 & 100,0 & \\
\hline \multirow{2}{*}{ Érvénytelen válaszok } & 306 & 19,4 & & \\
\hline Összesen & 1577 & 100,0 & & \\
\hline
\end{tabular}

6. táblázat: Szegények által lakottnak megnevezett területi egységek Szegeden.

\begin{tabular}{|l|l|r|r|r|r|}
\hline \multicolumn{2}{|c|}{} & Gyakoriság & $\%$ & Érvényes \% & Kumulatív \% \\
\hline \multirow{3}{*}{ Érvényes } & nem városrészt említett & 67 & 4,2 & 4,6 & 4,6 \\
\cline { 2 - 6 } & városrészt említett & 1396 & 88,5 & 95,4 & 100,0 \\
\cline { 2 - 6 } & Érvényes összesen & 1463 & 92,8 & 100,0 & \\
\hline Érvénytelen válaszok & 114 & 7,2 & & \\
\hline Összesen: & 1577 & 100,0 & & \\
\hline
\end{tabular}

7. táblázat: Gazdagok által lakottnak megnevezett területi egységek Szegeden.

A nem konkrét városrészekre vonatkozó említések területi egységkategóriánként különbözőek voltak. Az esetek nagyobb részében közterületek nevei jelentek meg a válaszokban, ezek közül is legnagyobb gyakorisággal a Cserepes-sor (60\%). A másik leggyakrabban említett területi egységkategória pedig a lakótelep ill. panel elnevezés volt $(16 \%)$.

A 2010-es adatfelvétel során kiemelkedően nagy arányban említett közterületek közül a Cserepes-sor mint szegény-szegregátum, lényegében Szeged egyik legismertebb cigánytelepe, amely Móravárosban, a városrész Alsóvárossal határos szélén helyezkedik el. A telep két városrész határán való elhelyezkedése valószínűleg szerepet játszhat abban, hogy a mentális térképeken egyesek Móraváros területéhez (89\%) kötik, mások pedig Alsóvároshoz (11\%) tartozónak vélik.

A Cserepes-sori szegényszegregátum ebből adódóan két városrészre fejt ki negatív extern hatást: Móravárosra és Alsóvárosra. A telep korábban mintegy zárványként ékelődött a város területébe, mára azonban egy új bevásárlóközpont felépítése kapcsán 
megszünt ez a korábbi zártság, és a telep körül olyan utak és terek nyíltak meg, amelyek jól láthatóvá teszik a telepet, valamint ezeken a közlekedési útvonalakon és tereken megnőtt forgalom következtében sokak számára vált láthatóvá ez a mikroszegregátum, amely hatása a mentális térképeken kimutatható.

A területi egységszintü másik leggyakoribb, de arányaiban jóval kisebb szegények által lakott területi elnevezés a ,panel, ill. lakótelep”. Ennél a területi egységlehatárolásnál, mint a szegények által lakottnak vélt részek esetében érezhetően erősebb kategorizációs hatások játszanak szerepet, melynek egyik magyarázó oka a nevezett lakóterület jellege. A lakótelepek egyik fő jellemzője az egy egységnyi területre jutó magas lakónépességen kívül az épületek fizikai jellemzőinek hasonlósága. ${ }^{14} \mathrm{~A}$ KSH által nem kiemelten, de szegregátumként nyilvántartott területek között csak ilyen lakótelepi területek találhatóak 2001-ben, mégpedig Tarján és az Északi város. Ezeken a területeken 2008-ra a szociális városrehabilitáció ugyan befejeződött, a negatív extern hatások számottevő csökkenése azonban 1-2 év távlatában még nem érzékelhető a mentális térképeken.

A 2001-es népszámlálási adatok valamint a mentális térképes adatfelvételek eredményeinek összehasonlítására - hogy a valóságban és a fejekben mennyire esnek egybe az alacsony és magas státuszúak lakóterületei - a népszámlálási adatbázis területi csoportosító változói és a szegediek fejében létező kognitív struktúra következtében a városrészek lehetnek alkalmasak.

A 2001-es népszámlálás adatai alapján a már előzőek során részletesen bemutatott két, társadalmi rétegződést meghatározó strukturális paraméter - iskolai végzettség és munkastátusz - alapján meghatározott alacsony ill. magas státuszú népesség városrészekre vonatkozó arányai szerint első lépésben rangsoroltuk a területeket, így az objektív adatok mentén két városrészenkénti rangsort állítottunk fel.

A 2007-2009-2010-es mentális térképes adatfelvételek alapján szintén rangsort állítottunk fel a városrészekre (kognitív struktúrákra) vonatkozó szegény, illetve

\footnotetext{
${ }^{14}$ Azonos épülettípusok, azonos építési technológiával
} 
gazdagok által lakott területként való említési gyakoriság alapján, amely eredményeként hat rangváltozót kaptunk. A rangsorok közötti összefüggéseket első lépésben rangkorrelációs elemzési módszerrel teszteltük.

\begin{tabular}{|c|c|c|c|c|c|}
\hline & & $\begin{array}{c}\text { Alacsony státuszú } \\
\text { területek rangsora } \\
\text { a 2001-es } \\
\text { népszámlálási } \\
\text { adatok alapján }\end{array}$ & $\begin{array}{c}\text { Szegények } \\
\text { által lakottnak } \\
\text { nevezett } \\
\text { területi } \\
\text { rangsor } 2007\end{array}$ & $\begin{array}{c}\text { Szegények } \\
\text { által lakottnak } \\
\text { nevezett } \\
\text { területi } \\
\text { rangsor } 2009\end{array}$ & $\begin{array}{c}\text { Szegények } \\
\text { által lakottnak } \\
\text { nevezett } \\
\text { területi } \\
\text { rangsor } 2010\end{array}$ \\
\hline \multirow[t]{3}{*}{$\begin{array}{c}\text { Alacsony státuszú } \\
\text { területek rangsora } \\
\text { a 2001-es } \\
\text { népszámlálási } \\
\text { adatok alapján }\end{array}$} & $\begin{array}{l}\text { Korrelációs } \\
\text { együttható }\end{array}$ & 1,000 & $-0,095$ & $-0,031$ & 0,091 \\
\hline & $\begin{array}{l}\text { Sig. }(2- \\
\text { tailed) }\end{array}$ & & 0,594 & 0,864 & 0,608 \\
\hline & $\mathrm{N}$ & 34 & 34 & 34 & 34 \\
\hline \multirow[t]{3}{*}{$\begin{array}{c}\text { Szegények által } \\
\text { lakottnak nevezett } \\
\text { területi rangsor } \\
2007\end{array}$} & $\begin{array}{l}\text { Korrelációs } \\
\text { együttható }\end{array}$ & $-0,095$ & 1,000 & $0,934(* *)$ & $0,893(* *)$ \\
\hline & $\begin{array}{l}\text { Sig. (2- } \\
\text { tailed) }\end{array}$ & 0,594 & & 0,000 & 0,000 \\
\hline & $\mathrm{N}$ & 34 & 34 & 34 & 34 \\
\hline \multirow[t]{3}{*}{$\begin{array}{c}\text { Szegények által } \\
\text { lakottnak nevezett } \\
\text { területi rangsor } \\
2009 \\
\end{array}$} & $\begin{array}{l}\text { Korrelációs } \\
\text { együttható }\end{array}$ & $-0,031$ & $0,934(* *)$ & 1,000 & $0,927(* *)$ \\
\hline & $\begin{array}{l}\text { Sig. }(2- \\
\text { tailed })\end{array}$ & 0,864 & 0,000 & . & 0,000 \\
\hline & $\mathrm{N}$ & 34 & 34 & 34 & 34 \\
\hline \multirow[t]{3}{*}{$\begin{array}{c}\text { Szegények által } \\
\text { lakottnak nevezett } \\
\text { területi rangsor } \\
2010\end{array}$} & $\begin{array}{l}\text { Korrelációs } \\
\text { együttható }\end{array}$ & 0,091 & $0,893(* *)$ & $0,927(* *)$ & 1,000 \\
\hline & $\begin{array}{l}\text { Sig. (2- } \\
\text { tailed) }\end{array}$ & 0,608 & 0,000 & 0,000 & \\
\hline & $\mathrm{N}$ & 34 & 34 & 34 & 34 \\
\hline
\end{tabular}

8. táblázat: 2001-ben alacsony státuszúak által lakott területek és a mentális térképeken (említési gyakoriság szerinti) 2007-2009-2010-ben szegényként említett területek rangsorának összefüggései

2001-ben az iskolai végzettség, és munkastátusz alapján alacsony státuszcsoportba sorolt szegedi lakosok területi arányszám szerinti rangsora nem mutat azonosságot egyik mentális térképes adatfelvételi év eredményeivel sem. A korrelációs együttható a 2007es rangsor esetében -0,095; 2009-re-0,031; 2010-ben pedig 0,091.

A három mentális térképes felvétel adatainak rangsora azonban erős összefüggést mutat, (2007-2009: 0,934; 2007-2010: 0,893; 2009-2010: 0,927) az eredményből azt a 
következtetést vonhatjuk le, hogy az alacsony státuszú lakosság 2001-es objektív adatok szerinti területi elhelyezkedése a fejekben hat, nyolc, illetve kilenc éves távlatban már teljesen eltérö. Ez az eltérés azonban a mentális térképeken, három éves összehasonlításban viszont stabil, szinte alig változik.

A magas státuszúak esetében más eredményekről számolhatunk be a rangkorrelációs elemzési eljárás lefolytatása után:

\begin{tabular}{|c|c|c|c|c|c|}
\hline & & $\begin{array}{c}\text { Magas státuszú } \\
\text { területek rangsora } \\
\text { a 2001-es } \\
\text { népszámlálási } \\
\text { adatok alapján }\end{array}$ & $\begin{array}{c}\text { Gazdagok } \\
\text { által } \\
\text { lakottnak } \\
\text { nevezett } \\
\text { területi } \\
\text { rangsor } 2007 \\
\end{array}$ & $\begin{array}{c}\text { Gazdagok } \\
\text { által } \\
\text { lakottnak } \\
\text { nevezett } \\
\text { területi } \\
\text { rangsor } 2009 \\
\end{array}$ & $\begin{array}{c}\text { Gazdagok } \\
\text { által } \\
\text { lakottnak } \\
\text { nevezett } \\
\text { területi } \\
\text { rangsor } 2010 \\
\end{array}$ \\
\hline \multirow{3}{*}{$\begin{array}{c}\text { Magas státuszú } \\
\text { területek rangsora } \\
\text { a 2001-es } \\
\text { népszámlálási } \\
\text { adatok alapján }\end{array}$} & $\begin{array}{l}\text { Korrelációs } \\
\text { együttható }\end{array}$ & 1,000 & $0,479(* *)$ & $0,499(* *)$ & $0,536(* *)$ \\
\hline & $\begin{array}{l}\text { Sig. (2- } \\
\text { tailed) }\end{array}$ & & 0,004 & 0,003 & 0,001 \\
\hline & $\mathrm{N}$ & 34 & 34 & 34 & 34 \\
\hline \multirow{3}{*}{$\begin{array}{c}\text { Gazdagok által } \\
\text { lakottnak nevezett } \\
\text { területi rangsor } \\
2007\end{array}$} & $\begin{array}{l}\text { Korrelációs } \\
\text { együttható }\end{array}$ & $0,479(* *)$ & 1,000 & $0,931(* *)$ & $0,853(* *)$ \\
\hline & $\begin{array}{l}\text { Sig. (2- } \\
\text { tailed) }\end{array}$ & 0,004 & & 0,000 & 0,000 \\
\hline & $\mathrm{N}$ & 34 & 34 & 34 & 34 \\
\hline \multirow{3}{*}{$\begin{array}{l}\text { Gazdagok által } \\
\text { lakottnak nevezett } \\
\text { területi rangsor } \\
2009\end{array}$} & $\begin{array}{c}\text { Korrelációs } \\
\text { együttható }\end{array}$ & $0,499(* *)$ & $0,931(* *)$ & 1,000 & $0,839(* *)$ \\
\hline & $\begin{array}{l}\text { Sig. (2- } \\
\text { tailed) }\end{array}$ & 0,003 & 0,000 & & 0,000 \\
\hline & $\mathrm{N}$ & 34 & 34 & 34 & 34 \\
\hline \multirow{3}{*}{$\begin{array}{l}\text { Gazdagok által } \\
\text { lakottnak nevezett } \\
\text { területi rangsor } \\
2010\end{array}$} & $\begin{array}{l}\text { Korrelációs } \\
\text { együttható }\end{array}$ & $0,536(* *)$ & $0,853(* *)$ & $0,839(* *)$ & 1,000 \\
\hline & $\begin{array}{l}\text { Sig. (2- } \\
\text { tailed) }\end{array}$ & 0,001 & 0,000 & 0,000 & \\
\hline & $\mathrm{N}$ & 34 & 34 & 34 & 34 \\
\hline
\end{tabular}

9. táblázat: A 2001-ben magas státuszúak által lakott területek és a mentális térképeken (említési gyakoriság szerinti) 2007-2009-2010-ben gazdagként említett területek rangsorának összefüggései

A 2001-ben magas státuszcsoportba sorolt szegedi lakosok területi arányszám szerinti rangsora erős összefüggést mutat a mentális térképes adatfelvételek gazdagok által lakott területként való említési rangsorával, ami azt jelenti, hogy a 2001-es objektív adatok alapján felrajzolt magas státuszú népesség aránya szerinti városrészenkénti 
területi struktúra, nagyban azonos a hat, nyolc ill. kilenc évvel későbbi mentális területi struktúrával.

X.6. A mentális szegregátum fogalmának bevezetése

A szegediek mentális térképére vonatkozó kvantitatív adatok elemzésekor a különböző társadalmi státuszú csoportok lakóhelyeire vonatkozóan területileg és a területhez kötődő jellemző sztereotípiák mentén is jól elkülönülő részeket határozhattunk meg.

Szeged egyes mentális terei a társadalmi státuszra vonatkozó meghatározások, illetve a különböző státuszokhoz kötődő jelzők, jellemző sztereotípiák estében is az említések százalékos arányai szerint jelentős különbségeket mutatnak, azaz mentálisan jól elkülönülő és meghatározott jelentéssel bíró szegregátumként is értelmezhetőek.

Értekezésünk során ezért egy új fogalom bevezetését és meghatározását láttuk szükségesnek, melynek a mentális szegregátum elnevezést adtuk.

Mentális szegregátumok alatt azokat a területi egységeket értjük, amelyek a mentális térképeken kirajzolódó mentális terekre vonatkozó meghatározó jelzők, vagy azonos tartalmat hordozó sztereotípiák említési gyakorisága legalább 15\%.

A fogalom bevezetésének és meghatározásának alapjául azok a kutatási eredmények szolgáltak, amelyek szerint az egyes emberek vagy a különböző társadalmi csoportok ugyanabból a konkrét reális térből érzékszerveikkel nemcsak mást és másképp érzékelnek, hanem különbözően értelmezik, értékelik is a tereket. A mentális térképes vizsgálatok során többször bebizonyosodott, hogy vannak jelenségek, térelemek, amelyek egyesek számára szinte észrevétlenek maradnak (nem hordoznak értékelhető információt), másoknak azonban éppen ezek a fontosak, és ezekben az esetekben nem az érzékszervi észlelés különbségei, hanem az egyéni és csoportos értékés érdekkülönbségek differenciálnak.

Ebből adódóan a tér nemcsak a tárgyiasult elemekből kiindulva írható le $\mathrm{s}$ értelmezhető, hanem a hozzá kapcsolódó tapasztalatok, tradíciók, értékek maguk is téralakító tényezők. (Nemes Nagy, 1998) 
Empirikus vizsgálataink eredményeképp Szegeden belül 2007-ben négy, 2009-ben és 2010-ben pedig három olyan városrészt határozhatunk meg, amelyek mentális szegregátumnak tekinthetők, ezek közül három szegény mentális szegregátumként (Tarján, Móraváros, Alsóváros), egy pedig gazdag mentális szegregátumként (Újszeged) jelent meg a szegediek mentális térképén.

\begin{tabular}{|c|r|r|r|r|r|r|}
\hline \multirow{2}{*}{ Városrész } & \multicolumn{3}{|c|}{$\begin{array}{c}\text { Szegények lakta területként említett } \\
\text { gyakoriság \% }\end{array}$} & \multicolumn{3}{c|}{$\begin{array}{c}\text { Gazdagok lakta területként említett } \\
\text { gyakoriság \% }\end{array}$} \\
\cline { 2 - 7 } & \multicolumn{2}{|c|}{2007} & 2010 & 2007 & 2009 & 2010 \\
\hline Alsóváros & 15 & 12 & 12 & 4 & 4 & 5 \\
\hline Móraváros & 22 & 28 & 28 & 0 & 0 & 1 \\
\hline Tarján & 22 & 24 & 21 & 0 & 0 & 0 \\
\hline Újjszeged & 1 & 0 & 0 & 69 & 74 & 70 \\
\hline
\end{tabular}

10. táblázat: Mentális szegregátumok Szegeden

2007-ben a legtöbbek által, említési gyakoriságukban a többihez viszonyítva kimagaslóan szegényként említett városrészek rangsor szerint: Tarján (21,66\%), és Móraváros (21,54\%). Alsóváros (14,93\%) 2007-ben a mentális szegregátumot meghatározó említési gyakoriság alsó határán van, majd 2009-től a városrész szegények által lakott területként való említése nem éri el a kritikus értéket. (10. táblázat)

2009-ben már csak két városrész az, ahol a szegediek szerint a legtöbb szegény lakik, és a rangsorban is változás következett be. 2009-ben a korábban azonos gyakorisági értéket kapott kimagaslóan szegényként említett városrészek rangsorában Móraváros és Tarján helyet cseréltek, és Móraváros (28\%), 4 százalékponttal került Tarján $(23,9 \%)$ elé.

A rangsor 2010-ben is ezt a két városrészt helyezi az élre, és a 2009-ben történt rangsorcsere is változatlan marad, de a különbség tovább nő, mely szerint: Móraváros 27,9\%; Tarján 20,5\%; Alsóváros 11,9\%-os említési gyakorisággal szerepel a szegényként említett városrészek rangsorában.

A rangsorban bekövetkezett változások véleményünk szerint a Szeged Napfénypark Bevásárlóközpont építése kapcsán végrehajtott térszerkezeti átépítések mentális térképekre gyakorolt hatásának következménye. A bevásárlóközpont felépítése a szegregátumként kiemelt területen, Móravárosban a Cserepes sor közvetlen 
szomszédságában zajlott, amely leginkább cigányok által lakott szegény szegregátum. A terület az átépítés előtt zárványként, alig láthatóan, a fö közlekedési útvonalaktól is elzártan ékelődött a város testébe. 2007-ben, az átépítés előtt végzett mentális térképes adatfelvételünkkor a megkérdezettek 21,54\%-a említette a városrészt úgy, mint szegények által lakott terület, majd a területrendezést és az építkezést követően, amelynek következményeként az említett szegregátum jól láthatóvá vált, valamint a bevásárlóközpont megnyitása után a forgalom is jelentősen megnövekedett ez az arány mintegy 28\%-ra növekedett.

Elemzési eredményeink alapján igazolható domináns szegregátum-hipotézisünk, mely szerint a szegregátumok típustól függetlenül megjelennek a mentális térképeken, és mentális szegregátum-hipotézisünk is, miszerint a mentális térképeken megjelenő szegregátumok határai nem esnek egybe a kvantitatív adatok alapján mért és lehatárolt szegregátumok határaival, a mentális szegregátumok határai kiterjedtebbek.

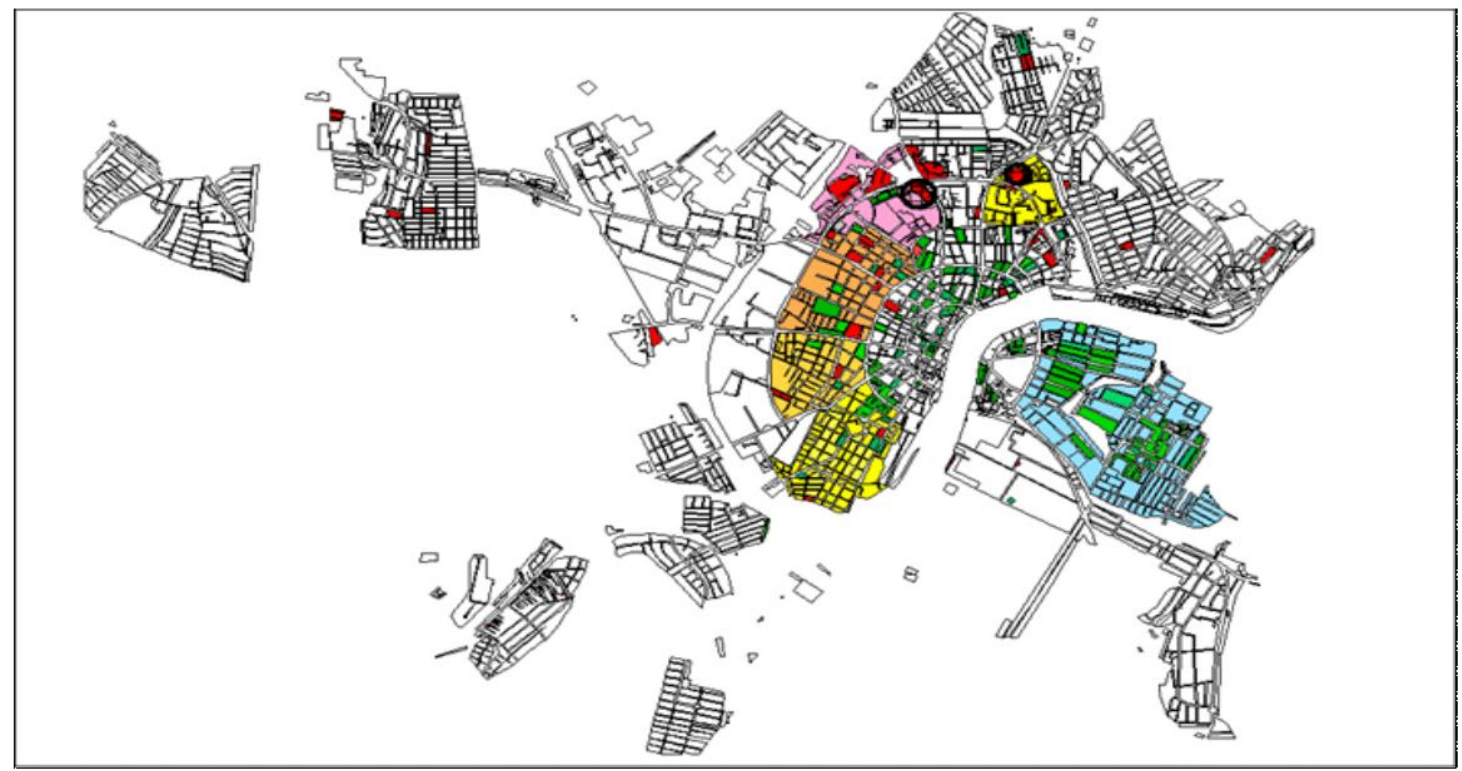

3. térkép: Az alacsony (piros) és magas (zöld) státuszúak 2001-es népszámlálási adatok felső decilisei szerinti területi elhelyezkedés és a mentális térképeken említett szegények (sárga, narancs, rózsaszín) és gazdagok (kék) által lakottként említett városrészek, a lakótelepeken kirajzolódó sürüsödési pontokkal (fekete kör). Saját szerkesztés 


\section{X.6.1. A valós és kognitív társadalmi-térbeli elkülönülés eltérö mintázatának magyarázatai}

Az általunk megfogalmazott és logikailag másodikként feltett kutatási kérdésre, nevezetesen, hogy a kognitív térképek mennyire pontosan reprezentálják a térbeli valóságot a különböző társadalmi csoportok területi elkülönülésében, az általunk vizsgált két különböző társadalmi csoport esetében eltérő eredményeket kaptunk. Az alacsony társadalmi státuszúak objektív adatok szerinti területi elhelyezkedése a szegedi mentális térképeken teljesen más, míg a magas társadalmi státuszúaké szinte megegyezik a 6-9 évvel később készült mentális térképes felvételek eredményeivel.

Az eltérő eredmények okára az alábbi lehetséges magyarázatokat fogalmaztuk meg:

\section{Dinamikus magyarázat}

A városrehabilitációs intézkedések leginkább az alacsony társadalmi státuszú lakosság lakóhelyét érintik, a beavatkozás következtében ezeken a területeken mennek végbe nagyobb változások, zajlanak le többször a különböző városökológiai folyamatok. A magas státuszú lakosság lakóhelyei nagyobb állandóságot mutatnak, itt nem következnek be gyakori nagymérvü változások. Szegeden a 2001. évet követő rehabilitációs intézkedések hatására az alacsony státuszú népesség területi megoszlása vélhetően megváltozott, amely változás a mentális térképeken is rögzült, míg a magas státuszúak már korábban a fejekben is rögzült helyzete a valóságban is változatlan maradt.

\section{Statikus magyarázat}

Ladányi és munkatársai kutatási eredményei valamint az általunk végzett Szegedre vonatkozó elemzések alapján, az alacsony státuszú népesség területi koncentrációja kisebb területi egységek esetében mutat csak nagyobb területi homogenitást, azaz a szegények lakta területek ún. mikroszegregátumok formájában erősen szórtan helyezkednek el a városon belül. Ennek következtében az egyéni tapasztalás útján konstruált városrészekre vonatkozó kognitív térképek, a szegények lakta területek erős szórtságából adóan a fejekben is erős szórtságot mutatnak, és a szubjektivitás jobban érvényesül az elhelyezkedést illetően. 
A mindennapi tapasztalás során az emberek egyrészt a város több részén találkozhatnak egy-egy szegények lakta mikroszegregátummal, másrészt azokkal a szegények által lakott kisebb területi egységekkel találkoznak gyakrabban, ahol a mindennapok során megfordulnak, így a kognitív területi meghatározás efelé a terület felé mutat majd. A szegények által lakottnak vélt városrészeket a fejekben az elhelyezkedésüket illetően egyrészt nagyobb szórtság jellemzi, másrészt a kategorizálás ezen szórtság következtében több területet érint. Ezzel ellentétben a nagyobb területi egységet lefedő magas státuszúak által lakott területtel csak a város egy-egy jól elkülönült, meghatározható részében találkozatnak, így a kognitív térképeken a szubjektív mindennapi tapasztalás különbözösége nem fejt ki nagy torzító hatást, a kognitív térképek nagyobb hasonlóságot mutatnak a valós térbeli-társadalmi elhelyezkedéssel.

Értekezésünk során definiáltuk a mentális szegregátum fogalmát, mely fogalom alatt azokat a területi egységeket értettük, amelyek a mentális térképeken kirajzolódó mentális terekre vonatkozó meghatározó jelzők, vagy azonos tartalmat hordozó sztereotípiák említési gyakoriságát tekintve más mentális terekhez képest meghatározó eltérést mutattak.

Kiindulva a társadalmi-térbeli elkülönülés tisztán kvantitatív mentális térképes vizsgálatából és a könnyen tanulható, „olvasható” város (Lynch, 1960; idézi: Cséfalvay, 1990) elméletéből, amely arra mutat rá, hogy a világosan tagolt szerkezetü, sajátos építészeti környezettel bíró városokról könnyen és gyorsan készíthető viszonylag pontos kognitív térkép, kiegészíthető azzal, hogy a társadalmi térbeli elkülönülés mentális térképes vizsgálatakor a nagyobb területi egységet lefedő, nagyobb homogenitással jellemezhető csoportokról, azaz az egyértelmű, „könnyen tanulható” társadalmi-térbeli elkülönültséggel leírható városokról - esetünkben városrészekről - készül viszonylag pontos kognitív térkép.

Kutatási eredményeink alapján a fentebbi két magyarázatunkkal véleményünk szerint azt az általános megállapítást is tehetjük, hogy a mentális térképek pontosságát két tényező nagyban befolyásolja, akár fizikai terek, akár társadalmi terek kognitív reprezentációinak a vizsgálatáról legyen szó: 
1. dinamikus tényező: az elemzési egységek (törésvonalak, határvonalak, iránypontok, mentális terek, sztereotípiák) területi változásainak gyakorisága

2. Statikus tényező: az elemzési egységek térbeli kiterjedése

\section{Sztereotip magyarázat}

A kognitív területi egyenlőtlenségek mérésére létrehoztunk a szegények, ill. gazdagok által lakott területként előforduló említési gyakoriságok alapján, egy indexet amelyet mentális disszimilaritási indexnek neveztünk el.

A mentális disszimilaritási index két kognitív kategória mentális térbeli megoszlását méri. A mutató alapvetően szimmetrikus, vagyis a két összevetett megoszlás szerepe, sorrendje felcserélhető A számítás lényege, hogy két kognitív kategória adott mentális területegységekhez kapcsolódó százalékos megoszlásainak területegységenkénti különbségeinek abszolút értékeit összegezzük, és osztjuk kettővel.

Az érték a mentális disszimilaritási index estében is 0 és 100 között mozoghat. Ha egy mentális térhez a fejekben nem kapcsolódik bizonyos sztereotípia, akkor értéke az alsó határérték felé mutat, míg bizonyos sztereotípia egy bizonyos területhez való kapcsolása esetén a felső irányába mozdul el. A 2007, 2009 és 2010-es adatok alapján Szeged városrészeire kiszámított mentális disszimilaritási index értéke az alacsony és magas státuszú népesség mentális térbeli eloszlását mutatja meg.

\begin{tabular}{|c|c|c|c|c|c|}
\hline \multirow{2}{*}{ Területi lehatárolás } & \multicolumn{2}{|c|}{ Disszimilaritási index } & \multicolumn{3}{c|}{ Mentális disszimilaritási index } \\
\cline { 2 - 6 } & \multicolumn{2}{|c|}{ Népszámlálás 2001 } & 2007 & 2009 & 2010 \\
\hline Városrészek & 27,72 & 29,5 & 85,94 & 86,80 & 83,77 \\
\hline
\end{tabular}

11. táblázat: A 2001-es népszámlási adatok valamint a mentális térképes adatfelvétel szerinti disszimilaritási és mentális disszimilaritási indexek városrészekre számított értékei Szegeden

A mentális disszimilaritási indexek 2007, 2009 és 2010-ben mért városrészekre vonatkozó értékei mintegy háromszorosai a 2001-es objektív adatok alapján kiszámított disszimilaritási index értékének.

A valós és kognitív társadalmi-térbeli mintázatok eltérésének lehetséges okaira vonatkozóan korábban már éltünk két magyarázattal, nevezetesen az általunk statikusnak 
és dinamikusnak elnevezett magyarázatokkal, ahol a társadalom térbeli elrendeződésének fejekben lévő eltérő mintázatát az első esetben a valós elrendeződés csoportspecifikus területi elhelyezkedési sajátosságaival (statikus), a második esetben pedig a városrehabilitációs intézkedések célterületenként eltérő gyakoriságával (dinamikus) magyaráztuk. Az eredmények tükrében egy harmadik magyarázatot fogalmazunk meg, nevezetesen a sztereotip magyarázatot.

A magyarázat lényege a különbözö társadalmi csoportok valóságban és fejekben való térbeli mintázatának különbözősége esetében nem más, mint a kategorizáció és a kategóriával társult túlzó nézetek gyakorisága és kiterjedése, amely a mentális terekhez kapcsolódó sztereotípiákat jellemzik.

A valós és kognitív társadalmi térbeli mintázatok eltérésének sztereotip magyarázata kapcsán az a kérdés merült fel bennünk a további vizsgálódásokat illetően, hogy a túlzó sztereotip magyarázatoknak van-e valamilyen hatása, avagy kimutatható-e olyan extern hatás, amely a kognitív térbeli mintázat torzulásainak a lehetséges következménye?

\section{X.7. Területi szegregátumok és externáliák}

Az értekezés további részében mentális szegregátum-hipotézisünket teszteljük, mely szerint a szegregátumokhoz kapcsolódó sztereotípiák kiterjednek a szegregátumokat magába foglaló nagyobb városszerkezeti egységekre, Szeged esetében a városrészekre, és ezáltal azokra kiterjedt pozitív vagy negatív extern hatásokat fejtenek ki. Azt feltételezzük, hogy ha egy szegregátum saját határain túlra mutató extern hatást fejt ki, akkor ez a hatás a mentális területi struktúra első szintjén (esetünkben a városrészek), a mentális terekhez kötődő kognitív reprezentációk minőségében és az azonos kategóriák mennyiségében is megmutatkozik, vagyis a pozitív illetve negatív sztereotípiák említési gyakorisága alapján mérhetővé válik.

A városokban keletkezhetnek negatív vagy pozitív extern hatások a különböző embercsoportok (gazdagok, szegények, fehérek, színes bőrűek, eltérő kultúrájú társadalmi csoportok stb.) között, de származhatnak extern hatások a közvetlen 
lakókörnyezet állapotából adódóan is, amely állapot jellemzőit determinálja az adott területen lévő szegregátum jellege. Ez alapvetően maghatározhatja a különböző társadalmi rétegek térbeli elkülönülésének mintázatát is a városon belül (LengyelMozsár 2002).

Feltételezésünk szerint a különböző területekhez kötődő sztereotípiák is befolyásolják az adott terület megítélést, és ennek kapcsán ugyancsak extern hatást fejtenek ki az adott területet érintő bárminemü tranzakciókra is. Ennek kapcsán egy bizonyos terület társadalmi megítélése - esetünkben a területhez kapcsolt pozitív vagy negatív sztereotípiák - extern hatást fejtenek ki az adott területre.

A sztereotip extern hatás kimutatására első lépésben megvizsgáljuk azt, hogy a különböző városrészek alacsony és magas státuszú lakónépességének objektív disszimilaritási és mentális disszimilaritási indexei között mekkora különbséget találunk. A városrészekre számított valósnak tekintett disszimilaritási indexek és mentális disszimilaritási indexek (10. táblázat) közötti különbség közel kétszeres volt, melynek okaként a sztereotip magyarázatot jelöltük meg (VII.5 fejezet). Az egyes városrészekre vonatkozó extern hatás mértékét a valós disszimilaritási és mentális disszimilaritási indexek területrészenkénti értékeinek különbségében fejezzük ki, majd annak alapján városrészenkénti rangsort állítunk fel a 2001-es bázis és a három adatfelvételi év mutatói szerint, majd a rangsorok korrelációja alapján teszteljük az összefüggést.

Az extern hatást kifejező mutató szerint mindhárom adatfelvételi évben Újszeged $(32,28 ; 34,68 ; 32,80)$, Móraváros $(12,47 ; 15,71 ; 15,30)$ és Tarján $(10,63 ; 11,72 ; 10,10)$ városrészek állnak a rangsor élén. Kimagaslóan nagy az extern hatást mutató érték Újszeged esetében, mintegy kétszer-háromszor akkora, mint a rangsorban utána következő két városrésznél.

A rangsort vezető három városrész közül kettő (Móraváros és Tarján) a KSH által is szegény szegregátumot vagy szegregációval veszélyeztetett területet magában foglalóan is meghatározásra került.

A harmadik városrészt, Újszegedet, az általunk végzett elemzés során határoztuk meg olyan területként, amely gazdag-szegregátumot foglal magába. Az eredmények alapján levonhatjuk azt az általános következtetést, hogy a sztereotip extern hatások 
leginkább a szegregátumokat magukba foglaló területeken érvényesülnek. A magasabb státuszúak által lakottnak vélt területekre vonatkozó sztereotip extern hatás kimagasló értéke pedig valószínűleg a szegregátum jellemzőivel - társadalmi homogenitás, és területi kiterjedés nagyságával - magyarázható.

A különböző területi egyenlőtlenségek számítási módszereinek ismertetése során az indexeket összetevő értékek felcserélhetőségével kapcsolatosan felhívtuk a figyelmet arra, hogy maga a területi egyenlőtlenséget mutató index nem ad közvetlen információt az indexeket összetevő részterületi egységek csoportonkénti arányának viszonyára, konkrétan arra, hogy az adott részterületen - pl. egy adott városrészben - mely csoport aránya nagyobb, avagy kisebb. A mentális disszimilaritási indexek számításakor ezért célszerűnek és logikusnak azt az eljárást véljük (amellett, hogy a mutató szimmetrikus), amikor is a pozitív kognitív kategóriából vonjuk ki a negatív kognitív kategória értékét, így az indexet kitevő mutatók előjele pozitív lesz, ha a pozitív kognitív kategória említési gyakorisága magasabb, és negatív lesz az előjel, ha a negatív kognitív kategória társul többségében az adott mentális térhez. A mentális terekhez kapcsolódó sztereotípiák által generált pozitív és negatív sztereotip extern hatások a mentális disszimilaritási indexeket kitevő, adott területrészekre vonatkozó mutatók valós értékei alapján kimutathatóak.

A 2001-es népszámlálási adatok alacsony és magas társadalmi státuszúak városrészenkénti disszimilaritási indexe és az azt kitevő értékek, valamint a 2007-ben, 2009-ben és 2010-ben végzett mentális térképes adatfelvételek gazdag (pozitív) és szegény (negatív) kognitív kategóriák esetében a mentális disszimilaritási indexek és az azt kitevő értékek az alábbiak szerint alakultak: 


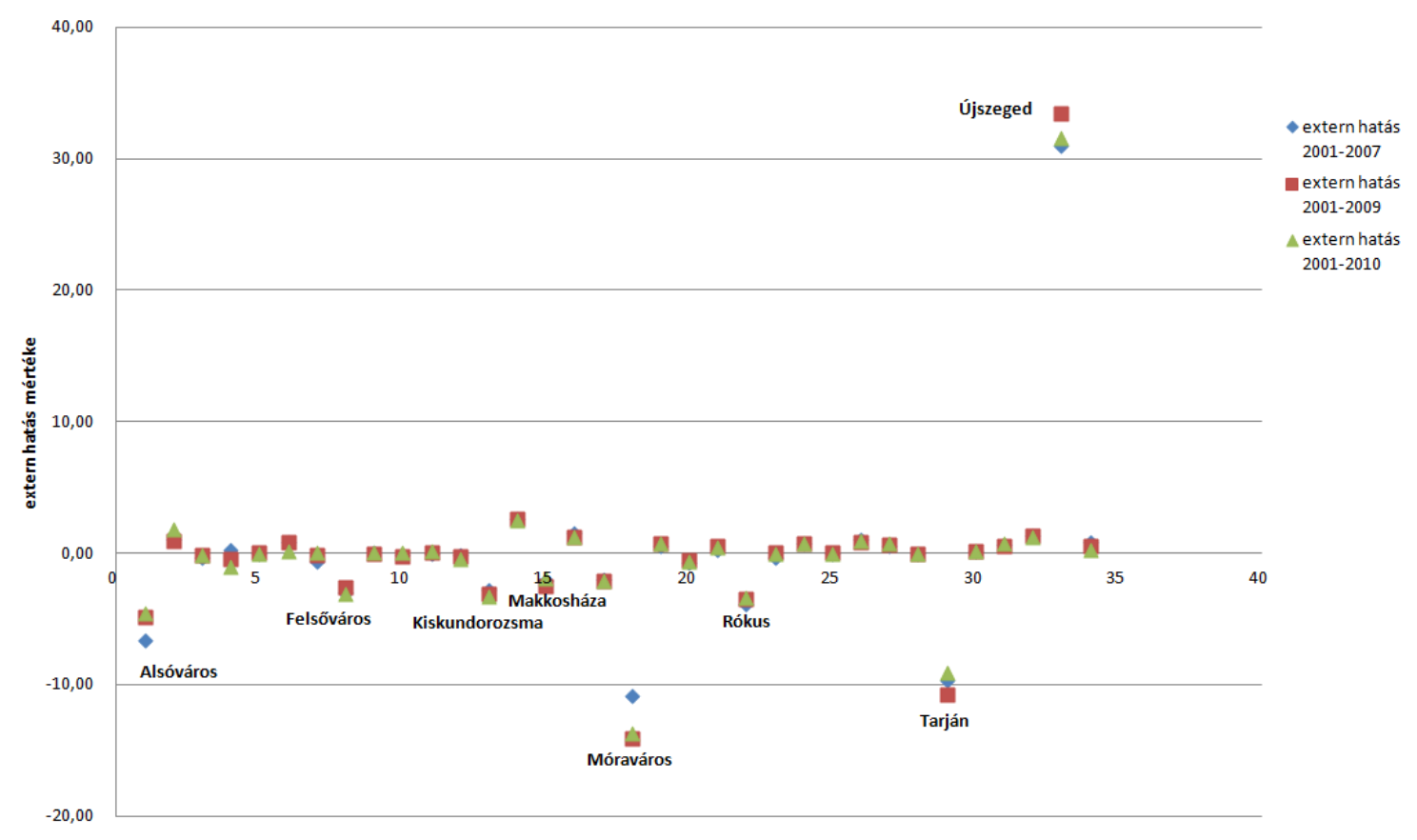

4. ábra: Sztereotip extern hatások alakulása városrészenként Szegeden

A legerősebb negatív sztereotip extern hatás mindhárom adatfelvételi évben Móravárosban és Tarjánban mutatható ki, amely városrészek szegény szegregátumokat foglalnak magukba. Pozitív sztereotip extern hatás számottevő mértékben csak Újszeged városrész esetében érzékelhető, a rangsorban következő Marostői kiskertek ugyanis mindössze csak 3,8-es értéket vesz fel.

Az elemzésünk alátámasztja sztereotip externália hipotézisünket, miszerint a szegregátumokhoz kapcsolódó sztereotípiák kiterjednek a szegregátumokat magába foglaló nagyobb városszerkezeti egységekre, Szeged esetében a városrészekre, és azokra kiterjedt pozitív vagy negatív extern hatásokat fejtenek ki. Jól látható, hogy a szegregátumokat magukba foglaló, vagy azokhoz közel eső városrészek esetében, az sztereotip extern hatások erősebbek. A területileg Móravároshoz tartozó, de Alsóváros határán elhelyezkedő Cserepes-sori cigánytelep negatív sztereotip extern hatása érzékelhető hatást fejt Alsóvárosra, mivel a mentális terek határai nem egyértelmüek, összemosódnak, amelynek következtében a szegregátum behatárolása is városrészi szinten elmozdul. A pozitív sztereotip extern hatásoknál a Marostői kiskertek esetében, amely Újszeged mellett található, ugyanez a helyzet. 


\section{X.8. Etnikai szegregáció és negatív sztereotípiák}

„,Mivel a hátrányos helyzetü etnikai csoportokat a társadalmi hierarchiában elfoglalt kedvezötlen helyükön túl az etnikai elöitéletek és ellenségeskedések egész rendszere sújtja, e népesség térbeli elhelyezkedése nemcsak erösebb, de alapvetöen más minta szerint is történik [...]." (Ladányi 2005:148)

Ladányi János fentebbi idézete ugyan az észak-amerikai nagyvárosok esetére vonatkozik (Ladányi 2005:147-148), azonban mivel értekezésünk fő kutatási irányvonala éppen a területekhez kötődő sztereotípiák vizsgálata, mindenképp fontosnak tartjuk bemutatni, hogy Szegeden a városrészekhez kapcsolódó negatív sztereotípiák egyértelmüen összefüggenek a városrészben található etnikai szegregátumok létezésével. A kérdőíves adatfelvételek alkalmával az egyes városrészek lakosságáról alkotott negatív sztereotípiákat a „,Vannak-e Szegeden belül olyan városrészek, ahol az ott élök miatt nem akarna lakni?" kérdéssel mértük, ahol a válaszadók három olyan városrészt nevezhettek meg, ahol kimondottan az ott élők miatt nem szívesen laknának. A válaszokat ezután egy nyitott kérdésben meg is indokolhatták.

A legtöbb említést, azok a városrészek kapták, ahol a valóságban vagy a városlakók tudatában cigánytelep található. Így a 771 említés közül leggyakrabban említett városrész kimagaslóan Móraváros (48\%), ahol a Cserepes sori cigánytelep található, majd Alsóváros (18\%) amely ugyan a statisztikai adatok alapján nem jellemzően szegények által lakott terület, de mivel határos Móravárossal és ennek a határnak egy részén húzódik a Cserepes sor, így a tudatban gyakrabban jelenik meg etnikai szegregátumként. Az említési gyakoriságokban egy markáns törés jelentkezik a rangsor második helye után. A harmadik helyezett Tarján városrész, ahol az adatok alapján nincs összefüggő etnikai szegregátum már csak 9\%-os említési gyakorisággal következik a rangsorban, majd ezt követi a másik cigánytelepet magában foglaló városrész, Dorozsma (8\%). Az említési gyakoriságokban bekövetkező drasztikus csökkenésnek a két városrész esetében véleményünk szerint az alábbi magyarázata lehet:

Tarján városrész esetében - amely egy lakótelepi városrész - mikroszegregátumokban, egy-egy közeli háztömbben, lépcsőházban lakott több-kevesebb cigánycsalád. A 
lakóövezet és a szegregáció mértéke tehát nem érte még el azt a méretet, amely a telepekre jellemző.

Dorozsma esetében a külvárosi elszigeteltség lehet a magyarázat arra, hogy annak ellenére, hogy etnikai szegregátumot foglal magában, mégis viszonylag kevesen említik.

A nyitott kérdésre adott válaszok szemantikailag igen változatosak voltak, föleg a tartalmában az etnikai jellegű sztereotípiákra vonatkozóan (cigányok, az etnikum, a kisebbség, romák, afromagyarok, sötét börüek, barnák, nem napon barnultak, malájok, $s t b)$. A három legtöbb említést kapott városrészbe a válaszadók többsége (Móraváros 57\%, Alsóváros 62\%, Dorozsma 69\%) az ott jelenlévő cigány lakosság miatt nem költözne. Elmondható, hogy a cigány lakossággal kapcsolatos negatív attitüd meglehetősen nagy méreteket ölt a megkérdezettek körében.

Az eredmények megerösítik, hogy a városrészek egészének e területek csak viszonylag kis részét képezik, a negatív sztereotípiák az egész városrészre vonatkoznak, azaz a városrészre negatív sztereotip extern hatást fejtenek ki.

\section{XI. ÖSSZEGZÉS}

Az értekezés Szeged társadalmi-térbeli mintázatának alakulásával kapcsolatos 10 évi kutatómunka eredményeit foglalja össze.

A társadalmi-térbeli elkülönülés Szeged városán belüli, több módszerrel történő vizsgálatához vezető fő motivációs tényező kereteit legfőképp Csanádi Gábor, Ekler Ferenc, Hegedűs József, Ladányi János és Tosics Iván (Ekler-Hegedűs-Tosics, 1980; Csanádi-Ladányi, 1988; Ladányi, 2008) elméleti és módszertani kritikái, valamint a különböző társadalmi státuszú csoportok eltérő szegregációs mintázataival kapcsolatos kutatási eredményei jelentették.

Az értekezés alapját képező kutatásunk módszertanát illetően a 10 év alatt sok változáson ment keresztül. Kezdetben kizárólag csak a kvantitatív módszerek, ezek közül is a mintavételes eljárásra építő survey típusú adatfelvételi módszerre alapoztunk, és a klasszikus városszociológiai elméletek társadalmi-térbeli elkülönülésével kapcsolatos modellek relevanciáját vizsgáltuk Szeged estében. A kutatásunk kezdeti 
irányvonalával szemben megfogalmazott jogos és építő szakmai kritikák először arra késztettek bennünket, hogy kutatási problematikánk elméleti kereteit kibővítsük és más módszertani megközelítésben is megvizsgáljuk. A társadalmi-térbeli elkülönülés problematikájának szociológiai megközelítése mellett a társadalomföldrajzi valamint a városgazdaságtani elméletekre is kiterjesztettük figyelmünket. Az elméleti keretek interdiszciplináris bővülése mellett az általunk vizsgált probléma módszertani megközelítése is bővült, amely bővülés a több vizsgálati módszer ötvözésének elméletére épített.

Kutatói érdeklődésünk mindvégig megmaradt a társadalmi-térbeli elkülönülés problematikája mentén, és ezt a problematikát értekezésünk során egy olyan sajátos szempontból ragadtuk meg, amely a területi-térbeli társadalmi mintázatok vizsgálata szempontjából talán újdonságnak is tekinthető, nevezetesen, hogy a statisztikai adatok mentén megrajzolható társadalmi-térbeli mintázatok valamint a fejekben létező kognitív társadalmi-térbeli mintázatok milyen eltérést mutatnak, ennek az eltérésnek mik lehetnek a magyarázatai, és milyen hatásokat fejhetnek ki egy-egy adott területre.

Történész végzettséggel is rendelkező szociológusként elöször csak a kezdeti strukturálatlan várostörténeti érdeklődés, majd pedig a mentális térképezés módszere iránti érdeklődés vezetett az értekezés fő irányvonalát adó hipotézisek teszteléséhez, melyek a kvantitatív és kvalitatív adatgyüjtés közben fogalmazódtak meg. Történeti városfejlődéssel kapcsolatos kérdésfeltevésünket még a forrás- és dokumentumelemzés során fogalmaztuk meg, majd ebből kiindulva más módszerek alkalmazásával megvizsgáltuk, hogy Szeged társadalmi-térbeli tagozódásának történeti változásai, hatással vannak-e 21. század városlakóinak Szegeddel kapcsolatos kognitív struktúrájára.

A kvalitatív és kvantitatív adatfelvételek eredményeinek elemzésével alátámasztottuk, hogy a jelentős hatású városszerkezeti átalakulások ma is meghatározóak a mentális térképeken megjelenő kognitív struktúrák határait illetően, ugyanakkor a történelmi városrészek egykori határvonalai egyre inkább már csak a fejekben - kognitív térképeken - léteznek, és csak azok a városrészek mutatnak némi eltérést ebben a tekintetben, amelyek egykor önálló települések voltak.

A kognitív struktúrák és történeti városrészek összefüggéseinek vizsgálatakor fordult kutatói érdeklődésünk a valós és kognitív társadalmi-térbeli elkülönülés 
problematikája felé. A problematika vizsgálatára egy kísérletet végeztünk, ahol a kiinduló vizsgálati pontként a 2001-es népszámlálási adatok alapján meghatározható és jól megragadható két társadalmi csoport (alacsony vagy magas státuszú, az adatfelvételek során érvényes megnevezéssel szegény vagy gazdag népesség) területi elhelyezkedését vizsgáltuk, különbözö területi egységenkénti lehatárolásban, majd vetettük össze, a két csoport hat, hét illetve kilenc évvel későbbi mentális térképeken megadott elhelyezkedésével.

A népszámlálási adatokon végzett elemzés Szeged esetében is alátámasztotta azokat a korábbi, mások által megfogalmazott megállapításokat (Ladányi 2008), melyek szerint a társadalmi hierarchia alján elhelyezkedők térbeli elkülönülést jelző indexei - az általában használatos, viszonylag nagy kiterjedésü területi lehatárolások esetében alacsonyabbak, mint a hierarchia tetején lévőknél. A tétel kiváltképp igaznak bizonyult abban az esetben, mikor az elkülönülést jelző indexet nagyobb területi egységekre vetítve határozzuk meg. Ekkor a területen belüli nagyobb társadalmi heterogenitás következtében láthatatlanná vált a kisebb területi egységekben egyébként létező és ott koncentrálódó szegregáció.

A kísérletképp megvizsgáltuk azt, hogy a szegediek kognitív térképein léteznek-e társadalmi jellemzöiket tekintve elkülönülő területek, és ha igen ezek a területek elhelyezkedésüket illetően milyen mértékü azonosságot mutatnak a 2001-es népszámlálási adatok alapján végzett, társadalmi-térbeli elkülönülést vizsgáló elemzésünk eredményeivel. A népszámlálási adatok (iskolai végzettség, és munkastátusz) alapján alacsony státuszcsoportba sorolt szegediek területi arányszám szerinti rangsora nem mutatott azonosságot egyik mentális térképes adatfelvételi év eredményeivel sem, viszont a magas státuszcsoportba sorolt szegedi lakosok területi arányszám szerinti rangsora erős összefüggést mutatott a mentális térképes adatfelvételek gazdagok által lakott területként való említési rangsorával.

A mentális térképes adatfelvételek eredményei mindhárom adatfelvételi évben a gazdag-szegény területi elkülönülés esetében hasonló kognitív struktúrát mutattak. Ennek alapján bevezettük és meghatároztuk a „,mentális szegregátum” fogalmát, amely alatt olyan a területi egységeket értünk, ahol a mentális térképeken kirajzolódó mentális terekre vonatkozó meghatározó jelzők, vagy azonos tartalmat hordozó sztereotípiák említési gyakorisága kimagasló. 
A mentális térképek pontosságára, vagy pontatlanságára vonatkozóan három lehetséges magyarázatot fogalmaztunk meg: A ,statikus magyarázat” valamint a dinamikus magyarázat" esetében, a társadalom térbeli elrendeződésének fejekben lévő eltérő mintázatát az első esetben a valós elrendeződés csoportspecifikus területi elhelyezkedési sajátosságaival (statikus), a második esetben pedig a városrehabilitációs intézkedések célterületenként eltérő gyakoriságával (dinamikus) magyaráztuk. A harmadik „,sztereotip magyarázat” lényege, hogy a különböző társadalmi csoportok valóságban és fejekben való térbeli mintázatának különbözőségét a mentális terekhez kapcsolódó sztereotípiák okozzák.

A valós és kognitív társadalmi-térbeli mintázatok eltérésének sztereotip magyarázata kapcsán az a kérdés merült fel bennünk a további vizsgálódásokat illetően, hogy a különböző szegregátumokat magukba foglaló területekhez kötődő, túlzó sztereotip magyarázatoknak van-e valamilyen hatása? A városgazdaságtan extern hatásokat taglaló elméleti megközelítését adaptáltuk a különböző minőségü szegregátumokat magukba foglaló területek megítélésével kapcsolatos vizsgálatunkra.

Az egyes városrészekre vonatkozó extern hatás mértékét a disszimilaritási és mentális disszimilaritási indexek területrészenkénti értékeinek különbségében fejeztük ki, majd annak alapján városrészenkénti rangsort állítottunk fel a 2001-es bázis és a három adatfelvételi év mutatói szerint, majd a rangsorok korrelációja alapján teszteltük az összefüggést. Az eredmények alapján kimutattuk, hogy a sztereotípiákból adódó extern hatások leginkább a szegregátumokat magukba foglaló területeken érvényesülnek. 
Felhasznált irodalom

Alonso, W (1964): Location and Land Use. Harvard University Press, Cambridge Angelusz Róbert (szerk.) (1999): A társadalmi rétegződés komponensei. Új Mandátum, Budapest

Aronowitz, S (2007): The ignored philospoher and social theorist. The work of Henri Lefebvre. Situations, Vol. 2, no. 1. 133-155. pp.

Babbie, E (2003): A társadalomtudományi kutatás gyakorlata. Balassi Kiadó Budapest Bajmócy Péter-Csikos Csaba (1997): Európai országok népszerüsége egyetemi hallgatók körében. Iskolakultúra 6-7. 71-77. pp.

Bálint Sándor (1959): Szeged városa. Képzőművészeti Alap Kiadóvállalata, Budapest Bálint Sándor (1976): A szögedi nemzet. A szegedi nagytáj népélete. Első rész. A Móra Ferenc Múzeum Évkönyve, Szeged

Balogh Péter (2007): A térbeli elkülönülés és a társadalmi rétegződés vizsgálata Szegeden. In: Rácz Attila (szerk.): Város és Vidéke. Településszociológiai tanulmányok. Belvedere Meridionale, Szeged 154-200 pp.

Benedek József (2003): Tér és regionalizáslás. In: Süli-Zakar I. (szerk): A terület- és településfejlesztés alapjai. Dialóg Campus Kiadó, Budapest-Pécs. 89-125. pp.

Berényi István (2003): A funkcionális tér szociálgeográfiai értelmezése. Földrajzi Tanulmányok 23. MTA Földrajztudományi Kutatóintézet, Budapest Béres Csaba (1983): A városfejlődés fordulópontján. KLTE, Debrecen Blau, P. M. (1976): Approaches to the Study of Social Structure. OPEN BOOKS, London

Blau, P. M. (2004): Egyenlőtlenség és heterogenitás. In: Angelusz Róbert (szerk.): A társadalmi rétegződés komponensei. Budapest, Új Mandátum 277-294. pp.

Boros Lajos - Hegedüs Gábor - Pál Viktor (2006): Globalizációs hatások alföldi városainkban - a városszerkezet és a településkép átalakulása. - III. Magyar Földrajzi Konferencia, Budapest CD-melléklet 
Boros Lajos (2009): Szeged belső térfolyamatai az 1950-es évektől napjainkig. Földrajzi Közlemények 133 (4) 453-465. pp.

Boros Lajos (2011): Szeged belső tagozódása a deprivációs indexek alapján. In: Rácz Attila (szerk.): Város és Vidéke. Településszociológiai tanulmányok 2. Kézirat Braun Róbert (1909): Adatok a vidéki munkásság életéhez. Huszadik Század 6.

Burgess, E.W. (1973): A városfejlődés: hipotézisek egy kutatási javaslathoz. In: Szelényi Iván (szerk.): Városszociológia. Közgazdasági és Jogi Könyvkiadó, Budapest 147-160 pp.

Castells, M. (1972): La question urbaine. Maspero, Paris

Castells, M. (1989): The informational city: information technologym economic restructuring and the urban-regional process. Blackwell Publishers, Oxford

Castells, M. (2005): Az információ kora. Gazdaság, társadalom és kultúra. I. kötet. A hálózati társadalom kialakulása. Gondolat-Infonia Kiadó, Budapest

Castells, M. (2007): Az évezred vége. Az információ kora. Gazdaság, társadalom és kultúra. III. kötet. Gondolat-Infonia, Budapest

Castells, M. - Ince, M. (2006): A tudás világa. Manuel Castells. Napvilág kiadó, Budapest

Csanádi Gábor - Ladányi János (1988): Társadalmi csoportok térbeni elkülönülésének különböző léptékekben történő vizsgálata Budapesten. Szociológia, 1988/1. 1-16 pp.

Csanádi Gábor - Ladányi János (1992): Budapest térbeni-társadalmi szerkezetének változásai. Akadémiai Kiadó, Budapest

Cséfalvay Zoltán (1990): Térképek a fejünkben. Akadémiai Kiadó, Budapest

Cséfalvay Zoltán (1994): A modern társadalomföldrajz kézikönyve. IKVA Könyvkiadó Kft., Budapest

Cséfalvay Zoltán (2008): Kapuk, falak, sorompók : a lakóparkok világa. Gondolat: Marina Part, Budapest

Csizmady Adrienne (2003): A lakótelep. Gondolat Kiadó, Budapest

Csizmady Adrienne (2008): A lakóteleptől a lakóparkig. ÚMK, Budapest 
Csizmady Adrienne - Husz Ildikó (szerk.) (2004): Település- és városszociológia. Szöveggyüjtemény. Gondolat Kiadó, Budapest

Dear, M. (2001): The postmodern turn. In: Minca, C. ed.: Postmodern geography. Theory and praxis. Blackwell Publishers, Oxford 1-36. pp.

Dear, M. - Flusty, S. (1988): Postmodern urbanism. Annals of the Association of American Geographers 88 (1). 50-72. pp.

Downs, R. M. (1970): Geographic Space Perception: Past Approaches and Future Prospects. Progress in Geography, 2: 65-108. pp.

Downs, R. M. - Stea, D. (1973): Cognitive Maps and Spatial Behavior: Process and Products. In: Downs and Stea ed.: Image and Enviroments. Aldine Publishing, Chicago Downs, R. M. - Stea, D. (1973b): Térképek az elmében - Gondolatok a kognitív térképezésröl. In.: Letenyei László (szerk.): Településkutatás. Szöveggyüjtemény. L'Harmattan Kiadó, Budapest 2004. 593-615. pp.

Downs, R. M. - Stea, D. (1977): Maps in Minds: Reflections on Cognitive Mapping. Harper and Row, New York

Dúll Andrea - Kovács Zoltán (szerk.) (1998): Környezetpszichológiai szöveggyüjtemény. Kossuth Egyetemi Kiadó, Debrecen

Duncan, O. D.-Duncan, B. (1973): Lakóhelyi szegregáció és foglakozási rétegződés. In: Szelényi Iván (szerk.): Városszociológia. Közgazdasági és Jogi Könyvkiadó. Budapest, 1973.

Duncan, O. D.-Duncan, B. (2000): Lakóhelyi szegregáció és foglalkozási rétegződés. In: Győri Péter (szerk.) (2000): A város, a város társadalma, életforma-csoportok. Társadalomismereti szöveggyüjtemény (Tanári kézikönyv) Wesley János Lelkészképző Főiskola Szociális Munkás Szak. Tótfalusi Tannyomda, Budapest 2000.

Duric, V. (1971): A lakás mint társadalmi jelenség és a lakásszociológiai kutatások sajátosságai. In: Szelényi Iván (szerk.): A szocialista városok és a szociológia. Kossuth Könyvkiadó, Budapest. 1971.

Egedy Tamás (2009): Városrehabilitáció és életminőség. MTA Földrajztudományi Kutatóintézet, Budapest Éhen Gyula (1897): Modern város. Bertalanffy József Könyvnyomdája, Szombathely 
Éhen Gyula (1903): A városok. Seiler H. Szombathely 1903.

Ekler Dezső - Hegedűs József - Tosics Iván (1980): A városfejlődés társadalmi-térbeni összefüggései Budapest példáján, I-III kötet BVTV, Budapest

Engels, F. (1845): A nagyvárosok (részlet). Manchester részletes leírása. In: Felkai Gábor - Némedi Dénes - Somlai Péter (szerk.): Szociológiai irányzatok a XX. század elejéig 1. köt. ÚMK, Budapest 2005. 233-249 pp.

Engels, F. (1980): A munkásosztály helyzete Angliában. Magyar Helikon, Budapest

Enyedi György (1988): A városnövekedés szakaszai. Akadémiai Kiadó, Budapest

Enyedi György (szerk.) (1998): Social change and urban restructuring in Central Europe. Akadémiai Kiadó, Budapest

Enyedi György (2004): Az urbanizációs ciklus és a magyar településhálózat. In: Csizmady Adrienne - Husz Ildikó (szerk.) (2004): Település- és városszociológia. Szöveggyüjtemény. Gondolat Kiadó, Budapest

Enyedi György (szerk.) (2007): A történelmi városközpontok átalakulásának társadalmi hatásai. MTA Társadalomkutató Központ, Budapest

Erdei Ferenc (1971): Város és vidéke. Szépirodalmi Könyvkiadó, Budapest

Erdei Ferenc (1974a): Magyar falu, Akadémiai Kiadó, Budapest

Erdei Ferenc (1974b): Magyar város. Akadémiai Kiadó, Budapest

Fahey, T. (2005): Urban spatial segregation and social inequality: a note on the potential for comparative European research. In: Whelan, C.T. ed: EU research on social sciences and humanities. 231-243 pp.

Farkas János (szerk.) (1998): Település- és városszociológia. Budapesti Műszaki Egyetem Természet és Társadalomtudományi Kar Szociológia és Társadalomtörténeti Tanszék. Müegyetem Kiadó, Budapest

Farkas József (2003): A társadalmi tér elméleti kérdései. Társadalomkutatás 21 (2). 167190. pp

Fava, S. F. (1960): Contrast in Neighbouring: New York City and a Suburban Community In: Dobriner: The Suburban Community 1960. 
Fejő - Niedermüller (1988): Témák és irányzatok a városok antropológiai-néprajzi kutatásában, Valóság, 1988/3. 48-59 pp.

Ferencz Gábor (2011): Lakóhelyi szegregáció és mentális térkép Szegeden 2009. In: Rácz Attila (szerk.): Város és Vidéke. Településszociológiai tanulmányok 2. Szeged, Kézirat

Ferenczi Imre (1906): A munkáslakás-kérdés különös tekintettel Budapestre. Kilián, Budapest

Füstös László (1988): Értéktérkép. 16 ország értéktérképe a gyermeknevelési elvek tükrében. MTA SZKI. Módszertani Füzetek, Budapest

Gans, H. J. (1962): A városi és a kertvárosi életmód. A meghatározások újraértékelése. In: Szelényi Iván (szerk.): Városszociológia. Közgazdasági és Jogi Könyvkiadó, Budapest 1973. 64-88 pp.

Giddens, 1997: Giddens, A.: Szociológia. Osiris Könyvkiadó. Budapest. 1997.

Giddens, A. (2003): Szociológia. Osiris Kiadó, Budapest. 2003.

Gint, N. P. - Fava, S. P. (1964): Urban Society, New York

Gold, J, R. (1980): An Introduction to Behavioural Geography. University Press, Oxford Gould, P. R. - Rodney R. W. (1974): Mental maps. Harmondsworth: Penguin, Pelican geography and environmental studies. (Második, javított és bővített kiadás: 1986, London, New York: Routledge.)

Gyáni Gábor (1998): Az utca és a szalon. Új Mandátum Könyvkiadó, Budapest Győri Péter (2000a): A várospolitika és a lakásépítés szerepe egyes szegregációs minták kialakulásában. In: Győri Péter (szerk.): A város, a város társadalma, életformacsoportok. Társadalomismereti szöveggyüjtemény. (Tanári kézikönyv.) Wesley János Lelkészképző Főiskola Szociális Munkás Szak. Tótfalusi Tannyomda, Budapest Győri Péter (szerk.) (2000b): A város, a város társadalma, életforma-csoportok. Társadalomismereti szöveggyüjtemény. (Tanári kézikönyv.) Wesley János Lelkészképző Főiskola Szociális Munkás Szak. Tótfalusi Tannyomda, Budapest Hall, E. T. (1969): The Hidden Dimension (1966), Garden City, Anchor Books, N.Y Hall, E. T. (1975a): The Hidden Dimension. Garden City, Anchor Books, N.Y 
Hall, E. T. (1975b): Rejtett dimenziók. Gondolat, Budapest

Hall, E. T. (1987): Rejtett dimenziók, ford. Falvay Mihály, 3. kiad., Gondolat, Budapest Harvey, D.(1985): The urbanization of capital. Blackwell, Oxford

Hegedűs Gábor (2007): Szeged lakóparkjainak általános jellemzői. In: Kovács CsabaPál Viktor (szerk.): A társadalmi földrajz világai. SZTE TTK Gazdaság- és Társadalomföldrajz Tanszék, Szeged 193-204 pp.

Hofer Tamás - Fél Edit (1997): Arányok és mértékek az átányi gazdálkodásban. Balassi, Budapest

Holahan, C. J. (1982): Environmental psychology. Random House, New York

Hoyt, H. (1964): A városi struktúra klasszikus modelljének újabb torzulásai. In: Szelényi Iván (szerk.): Városszociológia. Közgazdasági és Jogi Könyvkiadó, Budapest 1973. 161-182 pp.

Hunyadi László - Mundruczó György - Vita László (1997): Statisztika. Aula Kiadó, Budapest.

Hunyady György (1996): Sztereotípiák a változó közgondolkozásban. Akadémiai Kiadó, Budapest

Hunyady György (2001): Sztereotípiakutatás, hagyományok és irányok. ELTE Eötvös Kiadó, Budapest

Kanemoto, Y (1996): Externalities in Space. In: Arnott, R (ed.): Regional and Urban Economics. Part I. Harwood, 1996.

Kiss János Péter (2005): A mentális térkép. In: Nemes Nagy József (szerk.): Regionális elemzési módszerek. ELTE Regionális Földrajzi Tanszék MTA-ELTE Regionális Tudományi Kutatócsoport, Budapest. 96-98. pp.

Kiss János - Bajmócy Péter (1996): Egyetemi hallgatók mentális térképei Magyarországról. Tér és Társadalom, 2-3 sz., 55-70 pp.

Knox, P. - Pinch, S. (2006): Urban social geography - an itroduction. Pearson Prentice Hall, Harlow

Kolosi Tamás (1987): Tagolt társadalom. Gondolat Kiadó, Budapest 
Konrád György - Szelényi Iván (1971): A késleltetett városfejlődés társadalmi konfliktusai. Valóság, 12. sz.

Konrád György - Szelényi Iván (1971): A lakáselosztás szociológiai kérdései. In : Szelényi Iván (szerk.): A szocialista városok és a szociológia. Kossuth Könyvkiadó. Budapest 1971

Konrád György - Szelényi Iván (2004): A késleltetett városfejlődés társadalmi konfliktusai. In: Csizmady Adrienne - Husz Ildikó (szerk.) : Település- és városszociológia. Szöveggyüjtemény. Gondolat Kiadó, Budapest 2004

Kovács Zoltán (2002): Népesség- és településföldrajz. ELTE Eötvös Kiadó, Budapest

Kovács Tibor (szerk.) (2003): Nagyvárosok belső tagozódása: Szeged, Központi Statisztikai Hivatal Csongrád Megyei Igazgatósága. Kiadás száma: 7/2003.

Ladányi János (2000): A lakásrendszer változásai és a cigány népesség térbeni elhelyezkedésének átalakulása Budapesten. In: Győri Péter (szerk.): A város, a város társadalma, életforma-csoportok. Társadalomismereti szöveggyüjtemény. (Tanári kézikönyv.) Wesley János Lelkészképző Főiskola Szociális Munkás Szak. Tótfalusi Tannyomda, Budapest 2000

Ladányi János (2004): A zsidó népesség térbeni elhelyezkedésének változásai Budapesten 1870 és 2000 között. In: Helmich - Szántó, 2004.

Ladányi János (2007): A lakóhelyi szegregáció változó formái Budapesten. In Enyedi György (szerk.): A történelmi városközpontok átalakulásának társadalmi hatásai. MTA Társadalomkutató Központ, Budapest 2007.

Ladányi János (2008): Lakóhelyi szegregáció Budapesten. ÚMK Budapest

Ladányi János (szerk.) (2005): Szociális és etnikai konfliktusok. Tanulmányok a piacgazdasági átmenet időszakából (1987-2005) ÚMK, Budapest

Ladányi János - Szelényi Iván (1998): Class, ethnicity and urban restructuring in postcommunist Hungary. In: Enyedi György (szerk.): Social change and urban restructuring in Central Europe. Akadémiai Kiadó, Budapest 1998

Laky Dezső (1929): Budapest székesfőváros népességének fejlődése 1900-töl 1920-ig. Statisztikai Közlemények, 1929/1. 
Laky Dezső (1930): Az iparosok szociális és gazdasági viszonyai Budapesten. Statisztikai Közlemények, 1930/3.

Le Play (1855): Le Play, Frédéric Iobajjy ou paysans (a corvées) des plaines de la Theiss (Hongrie centrale). In: Le Play, Frédéric: Lex ouvriers européens. II. 272-303. Tours

Le Play (1903): Tiszamenti jobbágy (Hatvan). In: Le Play, Frédéric: A munkásviszonyok reformja. 495-516. (ford., bev. Geöcze Sarolta) MTA, Budapest

Lechner Lajos (2000): Szeged újjáépítése. 1891. 2000. Hasonmás kiadás

Lefebvre, H. (1991): The production of space. Basil Blackwell, Oxford

Lengyel Imre - Mozsár Ferenc (2002): A városi területhasználat monocentrikus modelljéről. Tér és Társadalom 2002/3. 1-26 pp.

Letenyei László (2001): Településtervezés és mentális térképezés. Falu, város, régió. 11-15. pp.

Letenyei László-Nagy Gábor Dániel (2007): Rugalmas kérdőív. Szociológiai Szemle, 2007/1-2. 29-45 pp.

Letenyei László (2004): Településkutatás. A települési és térségi tervezés társadalomtudományos alapozása. L’Harmattan Kiadó, Budapest

Letenyei László (2005): Településkutatás. A települési és térségi tervezés társadalomtudományos alapozása. L’Harmattan-Ráció Kiadó, Budapest

Logan J. R. - Molotoch H. L. (1999): The city as a growth machine. In: Fainstein S. Campbell S eds.: Readings in urban theory. Blackwell Publishers, Oxford. 1999. pp: 291-337.

Lowe, S. (1986): Urban social movements: the city after Castells. Macmillan, New York Lynch, K. (1960): The Image of the City. Technology Press, Cambridge (Massachusetts)

Malhotra, K. N. (2002): Marketing-kutatás. KJK-Kerszöv Jogi és Üzleti Kiadó, Budapest

Malinowski, B. (1922): Argonauts of the Western Pacific. Routledge, London 
Marton Ádám (1994): A nem mintavételi hiba az ipari kisszervezetek megfigyelésénél. Statisztikai szemle, 72. évfolyam 2. szám, 141 - 153. pp.

Mendöl Tibor (1936): Alföldi városaink morfológiája. Tisza István Egyetem, Debrecen Mészáros Rezső (2000) A társadalomföldrajz gondolatvilága. Szegedi Tudományegyetem Gazdaság- és Társadalomföldrajzi Tanszék, Szeged, 164. p.

Mészáros Rezső (1994): A település térbelisége. JATEPress, Szeged

Michalkó Gábor (1988): Mentális térképek a turizmus kutatásában. A magyar középiskolások Olaszország képe. Tér és társadalom 1-2. 112-129. pp.

Milgram, S. (1992): Psychological Maps of Paris. In: Milgram, Stanly: The Individual in a Socal World: Essays and Experiments. (Eds: John Sabini and Maury Silver.) McGraw-Hill. (Eredetileg megjelent: Ittelson, W. H., H. M. Prohansky és L. G. Rivlin (szerk.) 1976

Morris, R. N. (1968): Urban sociology. George Allen and Unwin Ltd., London

Nagy Lajos (1932): Magyar város: Alföldi város, Századunk, 46.

Nemes Nagy József (1992): Margójegyzetek a regionális politikához. Tér és társadalom. 1992/1-2 69-76 pp.

Nemes Nagy József (szerk.) (1998): A tér a társadalomkutatásban. Szó-Kép Kft., Budapest

Nemes Nagy József (2005): Összetett jelenségek, osztályozás, regionalizálás. In: Nemes Nagy J. (szerk.): Regionális elemzési módszerek. ELTE Regionális Földrajzi Tanszék MTA-ELTE Regionális Tudományi Kutatócsoport, Budapest. 169-186. pp.

Nemes Ferenc - Szelényi Iván (1967): A lakóhely mint közösség. Akadémiai Kiadó, Budapest

Németh Nándor (2005): Területi megoszlások eltérését mutató indexek. In: Nemes Nagy J. (szerk.): Regionális elemzési módszerek. ELTE Regionális Földrajzi Tanszék MTA-ELTE Regionális Tudományi Kutatócsoport, Budapest 111-117 pp.

Orum, A. M. - Chen, X. (2003): The world of cities. Places in comparative and historical perspective. Blackwell Publishing, Oxford. 
Park, R. E. - Burgess, E. W. - McKenzie, R. (1925): The City, Chicago, University of Chicago Press,

Peet, R. (2006): Modern geographical thought. Blackwell Publishing, Oxford.

Perényi Roland (2006): Városi tér és hatalom: „utcapolitika” a századfordulós Budapesten. Századvég 39. 28-54 pp.

Rácz Attila (szerk.) (2011): Város és Vidéke. Településszociológiai tanulmányok 2. Szeged, Kézirat

Rácz Attila (szerk.) (2007): Város és Vidéke. Településszociológiai tanulmányok. Szeged, Belvedere Meridionale

Rácz Attila (szerk.) (2009): Város és Vidéke. Településszociológiai tanulmányok 3. Szeged, JATEPress

Redfield, R. (1947): The Folk Society, The American Journal of Sociology

Rex, J. A. (2000): Az átmeneti övezet szociológiája. Győri Péter (szerk.): A város, a város társadalma, életforma-csoportok. Társadalomismereti szöveggyüjtemény. (Tanári kézikönyv.) Wesley János Lelkészképző Főiskola Szociális Munkás Szak. Tótfalusi Tannyomda, Budapest 2000.

Saád József (1977): A lakosság területi szegregálódása a városnövekedés folyamatában. Valóság, 1977. 3. sz. 78-87. pp.

Scipione, P. A. (1994): A piackutatás gyakorlata. Springer Hungarica, Budapest Shapiro, P. D. (2002): A Chicagói Iskola és a deviancia ökológiai megközelítése. In: Pikó Bettina (szerk.): A deviáns magatartás szociológiai alapjai és megjelenési formái a modern társadalomban. JATEPress, Szeged 2002. 27-43 pp.

Shevky, E. - Bell, W. (1961/1974): Sozialraumanalyse (Neuabdruck des Textes von 1961/dt. 1974). In: Riege, M. - Schubert, H. (szerk.): Sozialraumanalyse - Grundlagen - Methoden - Praxis. VS Verlag für Sozialwissenschaften, Wiesbaden, 79-96 pp.

Shields, R. (2004): Henri Lefebvre. In: Hubbard, P.-Kitchin, R.-Valentine, G. eds: Key thinkers on space and place. SAGE Publications, London 208-213. pp. 
Smith, N. (2000): Marxist geography. In: Johnston, R.J. - Gregory, D. - Pratt, G. Watts, M. eds.: The dictionary of Human Geography (fourth edition). Blackwell, London. 485-492. pp.

Soja, E. W. (1989): Postmodern Geographies: The Reassertion of Space in Critical 1989.

Soja, E. W.(2000): Postmetropolis: Critical Studies of Cities and Regions. Blackwell Publishers, Oxford

Soja, E. W.(2001): Afterword. In: Minca, C. ed.: Postmodern geography. Theory and praxis. Blackwell Publishers, Oxford 282-294. pp.

Stoltman, J. P. (1980): Mental maps: resources for teaching and learning. Geographical Association, Sheffield

Szelényi Iván (1972): Lakásrendszer és társadalmi struktúra. Szociológia, 1972/1.

Szelényi Iván (1990): Városi-társadalmi egyenlőtlenségek. Akadémiai Kiadó. Budapest.

Szelényi Iván (szerk.) (1971): A szocialista városok és a szociológia. Kossuth Könyvkiadó. Budapest. 1971.

Szelényi Iván (szerk.) (1973): Városszociológia. Közgazdasági és Jogi Könyvkiadó. Budapest. 1973.

Szelényi Iván-Konrád György (1969): Az új lakótelepek szociológiai problémái. Akadémiai Kiadó, Budapest

Szirmai Viktória (1988): „Csinált” városok. Magvető Kiadó. Budapest

Szirmai Viktória (1994): A településszociológia alapjai. Településtudományi felsőoktatási Füzetek 7. Sorozatszerkesztő: Szendrőné dr. Font Erzsébet, Budapest, Környezetvédelmi és Területfejlesztési Minisztérium Területi Tervezési Főosztály 1994.

Szirmai Viktória (1998): „Socialist” cities (new towns) in the postsocialist era. In: Enyedi György (szerk.): Social change and urban restructuring in Central Europe. Akadémiai Kiadó, Budapest 1998.

Telegdi László (1999): A nemválaszolás megelőzése és kezelése a gazdaságstatisztikában. Gazdaság és statisztika, 1999. augusztus-október 
Tversky, B. (1993): Cognitive Maps, Cognitive Collages and Spatial Mental Models. In: Frank, Andrew U. és Irene Campari (szerk.): Spatial Information Theory: A Theorethical Basis for GIS. Lecture Notes in Computer Science 716: 14 - 24 Berlin: Springer.

Varga-Ötvös Béla (1993): Értéktérkép. A települési ingatlanvagyon felmérésének módszere. Comitatus (3) 1.

Weber, M (1970): Állam, politika, tudomány : tanulmányok. Szerk: Kemény István, és Varga Iván, KJK. Budapest

Weclawowicz, G. (1998): Social polarisation in the postsocialist cities: Budapest, Prague and Warsaw. In: Enyedi György (szerk.): Social change and urban restructuring in Central Europe. Akadémiai Kiadó, Budapest 1998.

Whelan, C.T.-Layte, R.-Maitre, B. (2005): Social exclusion and multiple deprivation. In: Whelan, C.T. ed: EU research on social sciences and humanities. 199-205. pp

Willmott, P.-Young, M. (1960): Family and Class in a London Suburb., Routledge and Kegan Paul, London

Wirth, L. (1938): Az urbanizmus mint életmód, In: Szelényi Iván (szerk.): Városszociológia. Közgazdasági és Jogi Könyvkiadó. Budapest. 1973. 41-64. pp.

Zombori István (2004): A város újjáépítése. In: Kaján Imre - Zombori István (szerk.): A szegedi nagyárvíz és újjáépítés: Európa Szegedért. Vízügyi Múzeum és Könyvgyüjtemény Budapest és a Móra Ferenc Múzeum 44-49. pp.

Felhasznált források

A nagyvárosok belsö tagozódása. Szeged. KSH Csongrád megyei Igazgatósága, Szeged, 2003

ASZT 2008: Szeged Megyei Jogú Város Antiszegregációs Terve 2008.

VRK 2007: Városrehabilitáció 2007-2013-ban. Kézikönyv a városok számára. Budapest, Önkormányzati és Területfejlesztési Minisztérium Területfejlesztési és Épitésügyi Szakállamtitkárság 2007. 


\section{Melléklet}

\begin{tabular}{|c|c|c|c|c|c|c|c|}
\hline Városrészek & DI2001 & MDI2007 & MDI2009 & MDI2010 & SEE 2001-2007 & SEE2001-2009 & SEE2001-2010 \\
\hline Móraváros & 0,23 & $-10,65$ & $-13,9$ & $-13,50$ & $-10,88$ & $-14,13$ & $-13,7$ \\
\hline Tarján & $-1,15$ & $-10,81$ & $-11,9$ & $-10,24$ & $-9,66$ & $-10,75$ & $-9,1$ \\
\hline Alsóváros & 1,14 & $-5,51$ & $-3,75$ & $-3,38$ & $-6,65$ & $-4,89$ & $-4,5$ \\
\hline Rókus & $-0,39$ & $-4,29$ & $-3,85$ & $-3,79$ & $-3,90$ & $-3,46$ & $-3,4$ \\
\hline Felsőváros & 1,60 & $-1,38$ & $-0,95$ & $-1,51$ & $-2,98$ & $-2,55$ & $-3,1$ \\
\hline Kiskundorozsma & $-0,03$ & $-2,86$ & $-3,15$ & $-3,36$ & $-2,83$ & $-3,12$ & $-3,3$ \\
\hline Makkosháza & 0,28 & $-1,85$ & $-2,2$ & $-1,66$ & $-2,12$ & $-2,48$ & $-1,9$ \\
\hline Marostői kiskertek & 2,14 & 0,17 & 0,05 & 0,00 & $-1,98$ & $-2,09$ & $-2,1$ \\
\hline Öthalom & 0,59 & $-0,18$ & 0,05 & 0,00 & $-0,77$ & $-0,54$ & $-0,6$ \\
\hline Északi városrész & $-0,78$ & $-1,37$ & $-0,95$ & $-0,72$ & $-0,58$ & $-0,17$ & 0,1 \\
\hline Subasa & $-0,12$ & $-0,48$ & $-0,1$ & $-0,19$ & $-0,37$ & 0,02 & $-0,1$ \\
\hline Béketelep & $-0,60$ & $-0,90$ & $-0,75$ & $-0,77$ & $-0,29$ & $-0,15$ & $-0,2$ \\
\hline Kecskés-telep & 0,00 & $-0,18$ & $-0,2$ & $-0,39$ & $-0,18$ & $-0,20$ & $-0,4$ \\
\hline Gyálarét & $-0,25$ & $-0,37$ & $-0,5$ & $-0,22$ & $-0,12$ & $-0,25$ & 0,0 \\
\hline Sziksós & $-0,10$ & $-0,17$ & 0 & $-0,11$ & $-0,08$ & 0,10 & 0,0 \\
\hline Ipari övezet & $-0,29$ & $-0,37$ & $-0,25$ & $-0,11$ & $-0,07$ & 0,04 & 0,2 \\
\hline Bodomi kiskertek & 0,00 & $-0,06$ & 0,05 & 0,00 & $-0,06$ & 0,05 & 0,0 \\
\hline Tápéi kiskertek & $-0,04$ & $-0,04$ & $-0,05$ & $-0,08$ & $-0,01$ & $-0,01$ & 0,0 \\
\hline Fodor-kert & 0,09 & 0,16 & 0,05 & 0,18 & 0,07 & $-0,04$ & 0,1 \\
\hline Tompaszigeti kiskertek & $-0,18$ & 0,02 & 0 & $-0,06$ & 0,19 & 0,18 & 0,1 \\
\hline Petőfitelep & $-0,88$ & $-0,64$ & $-0,35$ & $-0,40$ & 0,24 & 0,53 & 0,5 \\
\hline Belváros & 4,48 & 4,76 & 4 & 3,46 & 0,28 & $-0,48$ & $-1,0$ \\
\hline Tápé & $-0,66$ & $-0,09$ & $-0,05$ & 0,08 & 0,57 & 0,61 & 0,7 \\
\hline Odessza & $-0,88$ & $-0,29$ & $-0,1$ & $-0,16$ & 0,59 & 0,78 & 0,7 \\
\hline Új-Petőfi-telep & $-0,16$ & 0,50 & 0,35 & 0,54 & 0,66 & 0,51 & 0,7 \\
\hline Szentmihály & $-0,68$ & 0,04 & 0,1 & 0,05 & 0,72 & 0,78 & 0,7 \\
\hline Egyéb külterület & $-0,94$ & $-0,13$ & $-0,1$ & $-0,82$ & 0,82 & 0,84 & 0,1 \\
\hline Újszőreg & $-0,19$ & 0,67 & 0,35 & 0,10 & 0,87 & 0,54 & 0,3 \\
\hline Baktó & $-0,19$ & 0,83 & 0,75 & 1,64 & 1,01 & 0,94 & 1,8 \\
\hline Szöreg & $-0,49$ & 0,56 & 0,35 & 0,46 & 1,05 & 0,84 & 0,9 \\
\hline Újrókus & $-1,50$ & $-0,18$ & $-0,15$ & $-0,31$ & 1,31 & 1,35 & 1,2 \\
\hline Marostő & $-0,63$ & 0,94 & 0,6 & 0,62 & 1,57 & 1,23 & 1,3 \\
\hline Klebelsberg-telep & $-2,62$ & $-0,05$ & $-0,05$ & $-0,11$ & 2,57 & 2,57 & 2,5 \\
\hline Újszeged & 3,19 & 34,20 & 36,6 & 34,75 & 31,01 & 33,41 & 31,6 \\
\hline
\end{tabular}

\section{5. ábra: Városrészenkénti sztereotíp extern hatások}

DI: A népszámlásái adatok alapján számolt disszimilaritási index

MDI: Mentális disszimilaritási index

SEE: Stereotype Extern Effect

SEE=MDI-DI 